\title{
Informat Report
}

UC-41

issued: April 1976

\section{Environmental Surveillance at Los Alamos During 1975}

\author{
dintar \\ Compiled by \\ K. E. Apt and V. J. Lee \\ Contributors
}
K. E. Apt
F. Miera
A. J. Ahlquist
J. W. Nyhan
S. Barr
W. D. Purtymun
D. Curtis
A. K. Stoker
T. E. Hakonson

Environmental Studies Group

An Affirmative Action/Equal Cpporlunity Emplayer 


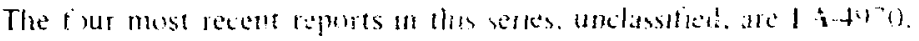
LA+5184. LA-5586, and LA-5977-PR.

Printed in the United States of America. Avajiable from National Technical Information Service

U.S. Department of Commerce

5285 Port Royal Road

Springfield, VA 22161

Price: Printed Copy \$4.50 Microfiche \$2.25 


\section{CONTENTS}

ABSTRACT

I. INTRODUCTION

A. Physical setting

B. Meteorology

II. SUMMARY OF RESULTS

III. STATEMENT OF PARTICULARS

A. Geographic Coordinate System and Access Control

B. Units of Measurement and Statistical Treatment of Data

C. Standards for Environmental Contaminants

D. Analytical quality Control program

IV. ENVIRONMENTAL RELEASES FROM LASL OPERATIONS

v. EXTERNAL PENETRATING RADIATION

A. Procedures

B. Results

VI. RADIOACTIVITY IN AIR

A. Sampling Procedures

B. Daily Radioactivity

C. Tritium

D. Gross Radioactivity

E. Plutonium and Americium

F. Uranium

VII. FADIOACTIVITY IN SURFACE AND GROUND WATERS

A. On-site Surface and sround Naters

B. Off-site tnō Supply Waters

VIII. RADIOACTIVITY IN SOILS AND SEDIMENTS

IX. RADIOACIIVITY IN FOODSTUFFS

$X$. RADIATION DOSE ASSESSMENT

A. Methods and Assumptions

B. External Penetrating Radiation

C. Radioactivity in Air

D. Other Nuclides and Patbways

$X I$. CHEMICAL QUALTTY OF SURFACE AND GROUND WATERS

A. On-Site Surface and Ground waters

B. Off-Site and Supply waters

C. Fenton Hill site surface and Ground Waters

XII. ECOLOGICAL STUDIES

A. Long-Term Ecological Effects of Exposure to Uranium

B. Sto:m Runoff Transport of Plutonium in Mortandad Canyon

C. Radionuclides in Rio Grande Sediments and Fish

XIII. UNPLANNED RELEASES

REFERENCES

TABLES

DISTRIBUTION LIST

Tus tepor1 was prepared as an account or work

sponsored by the Unted Stales Government Neut the United States now the Unried State Fneige

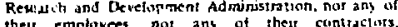

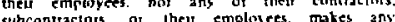
womanly. express al impled. me assumes amt lectl toshiluty or tespernsibility fot the sicuracy, completene si

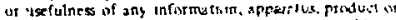

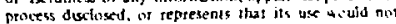
infonpe progtely awned jights. 
I. Means and Extremes of Temperature and Precipitation 33

II. Units of Measurement Conversions 34

III. Minimum Dectection Limits (MDLs) for Routine Anaiyses of Radioactivity
in Typical Enviromental Samples

IV. ERDA Radioactivity Concentration Guides (CGa) 36

V. Water Standards 37

VI. Atmospheric Radioactive Effluent Totals for 1975

VII. Annual Thermoluminescent Dosimeter Measurements 39

VIII. Summary of Annual. Atmospheric Radioactivity Monitoring 40

IX. Annual Atmospheric T:itiated Water Vapor Concentrations 41

$X$. Annual Atmospheric Gross-Alpha and Gross-Beta Activity Concentrations 42

$X I$. Annual Atmospheric ${ }^{238} \mathrm{Pu}, 239 \mathrm{Pu}$, and ${ }^{241} \mathrm{Am}$ Concentrations 43

XII. Annual Atmospheris Uranium Concentrations 44

XIII. Radioactivity in on-Site Surface and Ground Water 45

XIV. Radioactivity in off-site and Supply Waters 46

XV. Radioactivity in soil and Sediments 47

XVI. Chemical Quality of On-Site surface and Ground waters 48

XVII. Chemical Quality of Perimeter surface and Ground Waters 49

XVIII. Chemical Quality of Regional surface Water 50

XIX. Chemical Quality of the Los Alamos Water supply 51

$\mathrm{XX}$. Chemical Quality of Water in the vicinity of Fenton Hill 52

$\mathrm{XXI}$. Rio Grande Radionuclide Survey 53

\section{FIGURES}

1. Topography of the Los Alamos, New Mexico, area v

2. North-central Nev Mexico 3

3. 1975 wind roses 5

4. Los Alamos County residential areas and LASL technical areas. 7

5. Tritium in water crosscheck pregram 10

b. Gross-beta in water crosscheck program 10

7. Cesium-137 in water crosscheck program 10

8. TLD and air sampler locations 13

9. Daily gross-beta radioactivity for 1975

10. Wacer, sediment, and soil sampling locations on or near the LAEL g1te 19

11. Regional surface water, sediment, and soil sampling locations 20

12. Fenton Hill Sampling station map 27 


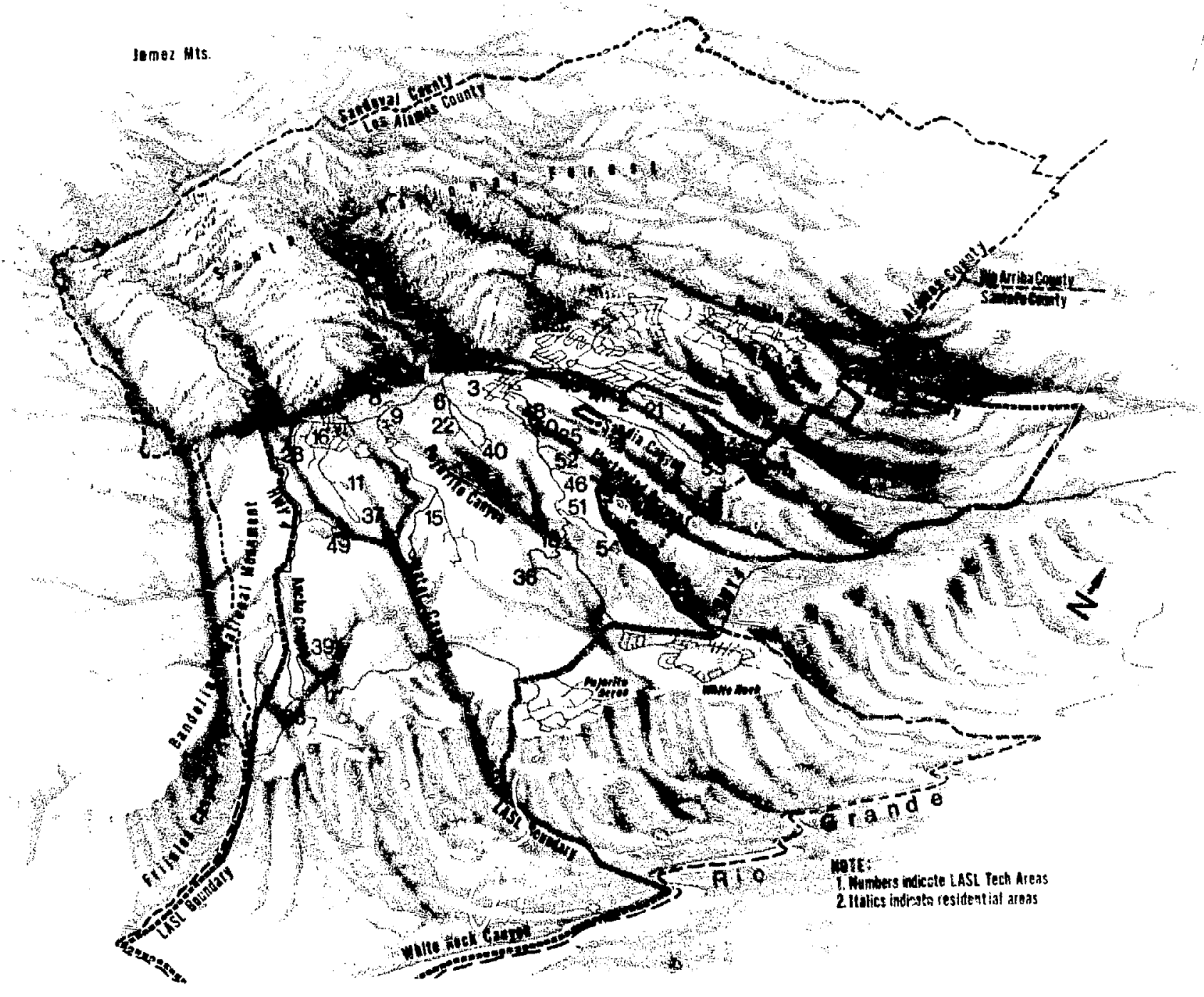

Fig. 1. Topograrhy of the Los Alamos, New Mexico, arca, 
ENVIRONMENTAI, SURVEILLANCE AT LOS ALAMOS

DURING 1975

Compiled by

K. E. Apt and v. J. Lee

\section{ABSTRACT}

This report documents the CY 1975 environmental monitoring program of the Los Alamos Scientific Laboratory (LASL). Data are presented for concentrations of radioactivity measured in air, ground and surface waters, sediments, sojls, and foodstuffs, and are compared with relevant U.S. Energy Research and Development Administration guides and/or data from other reporting periods. Levels of external penetrating radiation measured in the LASI environs are given. The average whule-body radiation dose to residents of Los Alamos County resulting from LASI, operations is calculated. Chemical qualities of surface and ground waters in the LASL environs have been determined and compared to applicable standards. Results of related environmental studies are summarized.

\section{INTRODUCTION}

This report documents the results of the anvironmental monitoring program conducted at the Los Alamos Scientific Laboratory (LASL) during CY 1975. In keeping with Energy Research and Development Administration (FRD.1) and Laboratory intent to keep information on environmental quality available to the pitilic, it principally serves the purpose of providing public documentation of data on environmental quality and conditions in the vicinity of the Laboratory. In accordance with iASL contractual agreement, it additionaliy complies with the requirements specified in ERDA Manual Chapter (ERDAM) 0513.

LASL is administered by the University of California for ERDA, under contract W-7405-ENG-36. The LASL environmental program is conducted by the Erivironmentai
Studies Group (Group H-8) as part of continuing environmental investigation and documentation.

Since its inception in 1943, the Laboratory's primary mission has been nuclear weapons research and development. In addition to its national security programs. which include weapons development, laser fusion, nuclear materials, and laser isotopes separation, LASL conducts research programs in the physical sciences, energy research and development, and biomedical and environmental studies.

F. Physical Setting

The Los Alamos Scientific Laboratory and the residential communities of Los Alamos and White Rock are located in Los Alamos County in north-central New kexico, about $100: n$ NNE of Albuquerque and $40 \mathrm{~km}$ NW of Santa Fe, by air. The $110-\mathrm{km}^{2}$ Laboratory site and adjacent communities are situated 
on the Pajarito Plateau which corsists of 3 series of mesas separated by deep canyons that run eastward from the Jemez Mountains to the Rio Grande valley. Most Laboratory and community development is confined to the mesa tops. The surrounding land is essentially undeveloped. Large tracts of land north, west, and south of the Laboratory site are neld by the U. S. Forest service and U. S. Natioral Park Service. Indian pueblo lands border the Laboratory to the east (Figs. 1 and 2). The major piant associations of the area are coniferous forests and piñon-juniper bushlands whlch support a typical variety of western mountain wildife.

North-central New Mexico contains approximately one-half million people, of whom nearly $70 \%$ are concentrated in Albuquerque and another 108 are located in Santa Fe. The remainder of the population is distributed among small towns and Indian pueblos ranging in size from a few hundred to a few thousand inhabitants. About 12000 people live in the residential area of Los Alamos proper and some 5700 more reside in the White Rock area.

The economy of the Santa Fe/Los Alamos area is based largely on Government operations (IASI and the New Mexico State Government offices in Santa $F e)$, large tourist trade, arts and crafts, and some light service industries. Subsistence agriculture is practiced to a limited extent within 20 to $40 \mathrm{~km}$ of Los Alamos. In the immediate area (less than $20 \mathrm{~km}$ from LASL) home gardening is practiced but is insignificant from the population subsistence viewpoint. B. Meteorology

Los Alamos has a semiarid continental mountain climate. The arnual precipitation of $46 \mathrm{~cm}$ is accounted for by warm-season orographic convective rain showers and winter migratory storms. Seventy-five percent of the annual total falls between May and October, primarily as thunderstorms. Peak shower activity is in August, when one day in four will have at least $2.5 \mathrm{~mm}$ of rain accumulation and some rain is observed on half of the days. The annual average of 62 thunderstorm-days per year makes this area equivalent to the Guif coast states in thundershower occurrence The showers tend to develop in early afternoon, with a secondary maximum about $1800 \mathrm{MST}$. They are accompanied by lightning, gusty surface winds (10$20 \mathrm{~m} / \mathrm{s}$ ), and occasional hail. Tornadces have not been observed in tis area.

Winter precipitation falls primarjly as snow with annual accumulations of about $1.3 \mathrm{~m}$. The water equivalent of snowfall in Los Alamos varies betweer $1: 10$ and $1: 20$, the latter occurring in cold conditions and higher altitudes.

Summers are cool and pleasant. Maximum temperatures are generally b.zlow $32^{\circ} \mathrm{C}$, and a large diurnal variation keeps nocturnal temperatures in the $12-15^{\circ} \mathrm{C}$ range. Winter temperatures are typically in the range from $-10^{\circ} \mathrm{C}$ to $5^{\circ} \mathrm{C}$. Many winter days are clear with light winds, and sirong solur radiation makes conditions quite comfortable even when air temperatures are cold. The annual total of heating degree days (Celsius) is 3500 , with January accounting for over 610 while July and August average zero degree days. An analysis of one year's solar radiation is described by Balcomb et al. ${ }^{1}$ BY estimating an envelope to the observations of daily insolation, an annual observed value of about two-thirds the potential insolation is obtained. The reduction is due to cloudiness, implying that approximately one-third of the day? ight hours in one year were affected by cloudiness. The most cloud-free month (January) had 858 of potential insolation while the minimurn (July) had 558 .

Average relative humidity is $40 \%$, ranging from 3 ) 8 in May and June to above $50 \%$ in July, January, and Februar $F$. The diurnal variation is very large and basically inverted to the diurnal temperature cycle. The summer mor ths have nocturnal maxima of $80 \%$ and minima of $30 \%$, while the driest 


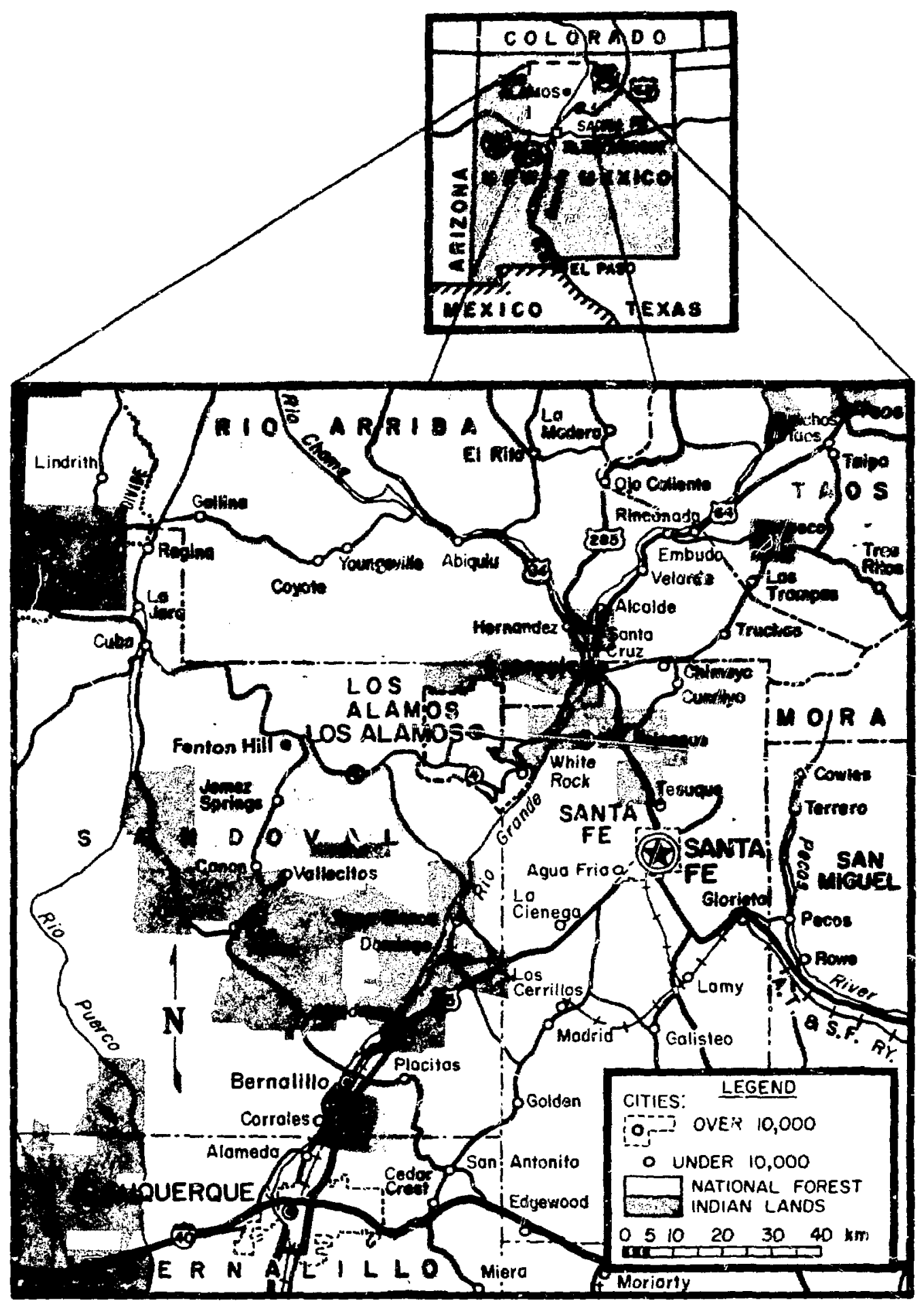

Fig. 2. North-central New Mexico. 
time, spring, has a diurnal range from 15508.

The local conditions for the transport and dilution of air contaminants are of interest. Atmospheric diffusion depends on three primary considerations: source factors (size, duration, elevation-above-ground, temperature), tercain factors (roughness. slope, vegetative cover, solar heating), and meteorological factors (wind speed and direction, temperature, stratification, turbulence energy). There is considerable interdependency among all of the factors listed, and many of the available formulae for estimating atmospheric dispersion represent atcempts at generalizing the interrelationships. The fundamental formulaticn for most practical diffusion prediction. schemes is the Gaussian plume model, which can be expresset as

$$
x=\frac{Q_{i}}{(2 \pi)^{\frac{3}{2}} \sigma_{y}(x) o_{z}(x) \sigma_{x}(x)}
$$

$x \exp \left\{-\left[\frac{(x-\bar{u} t)^{2}}{2 \sigma_{x}{ }^{2}(x)}+\frac{y^{2}}{2 \sigma_{y}{ }^{2}(x)}+\frac{z^{2}}{2 \sigma_{z}{ }^{2}(x)}\right]\right\}$

for instantaneous sources, or

$$
x=\frac{Q_{c}}{\pi \vec{u} \sigma_{y}(x) \sigma_{z}(x)}
$$

$x \exp \left[-\frac{1}{2}\left(\frac{y^{2}}{\sigma_{y}^{2}(x)}+\frac{z^{2}}{\sigma_{z}^{2}(x)}\right)\right]$

for continuous sources. In this framework, the diffusion parameters $\sigma_{y}$ and $\sigma_{z}$ can be interpreted as a measure of the plume's lateral and vertical dimensions at appropriate distances $x$. Various authors have used different empirical meteorological parameters to specify $\sigma_{y}, \sigma_{z}$, including wind speed, temperature profiles, time-ofday, cloudiness, and direct measure of gustiness. A comparison of a number of frequently used methods, and the frequency of occurrence observed during a 1-yr experi-

\begin{tabular}{|c|c|c|c|c|c|c|}
\hline \multirow[b]{2}{*}{ Description } & \multirow{2}{*}{$\begin{array}{l}\text { rasq- } \\
\text { uill1 }\end{array}$} & \multirow[b]{2}{*}{$\therefore A^{a}$} & \multirow{2}{*}{$\begin{array}{l}\text { Wind } \\
\text { Dir. } \\
\text { Range }\end{array}$} & \multicolumn{2}{|c|}{ Sutton } & \multirow{2}{*}{$\begin{array}{l}\text { Preq } \\
\text { of } \\
\text { Ocrus }\end{array}$} \\
\hline & & & & $\stackrel{c}{c}$ & 포 & \\
\hline Very atable & $\boldsymbol{F}$ & $2.3 *$ & $0-30=$ & .21 & .50 & $2 .+1$ \\
\hline stable & $\mathbf{z}$ & $4.60^{\circ}$ & $30-60^{\circ}$ & .12 & .33 & 24.1 \\
\hline Mear noutral & D & $7-10^{\circ}$ & $60-90^{\circ}$ & .03 & .25 & 25.7 \\
\hline modarately unstable & $c$ & $10-150$ & $90.120^{\circ}$ & .07 & .22 & 27.1 \\
\hline Unueable & B & $15-20^{\circ}$ & $120-100^{\circ}$ & .06 & .20 & 21.4 \\
\hline Extramly unstable & $\wedge$ &, $20^{\circ}$ & $2000^{\circ}$ & - & - & 8.9 \\
\hline
\end{tabular}
ment at TA-3, is shown below:

standard deviation of aximuth wind direction fluctuationa.

The application of the meteorslogical parameters depends on modeling assumptions tying them to the diffusion cocfficients, either mathematical expressions (such as power laws in downwind distance), tables or graphs of $\sigma_{y}, \sigma_{z}$ vs $x$, and the above paraneters. Such relationships are readily available in references such as slade. ${ }^{2}$ Pasquill, ${ }^{3}$ or Cramer et al. 4

Table I shows the means and extremes of temperature and precipitation for the entixe period of recora, and separately, for 2975 . By comparison, 1975 was generally cool and wet. Temperatures were below average in every month except December. A heavy surplus of precipitation in late winter and spring offset dry months in May, June, and August. July and September had above-average rain; however, very dry conditions were established in the last three months of the year.

wind roses, shown in $\mathrm{Fig} .3$, are indicators of atmospheric transport of contaminants. Under stable conditions, the influence of topography is maximized in a northwest-southeast major axis orientation-basically parallel with the slope of the Pajarito plateau. The winds, under stable daytime conditions, tend to be somewhat more uniformly distributed in airection, responding to the variety of pressure gradients induced by migratory weather systems. The periods reflecting the sinrise and sunset transitions are not distinctly different from the nocturnal regimes. The wind data presented here were collected from a location un the roof of the Administration. 


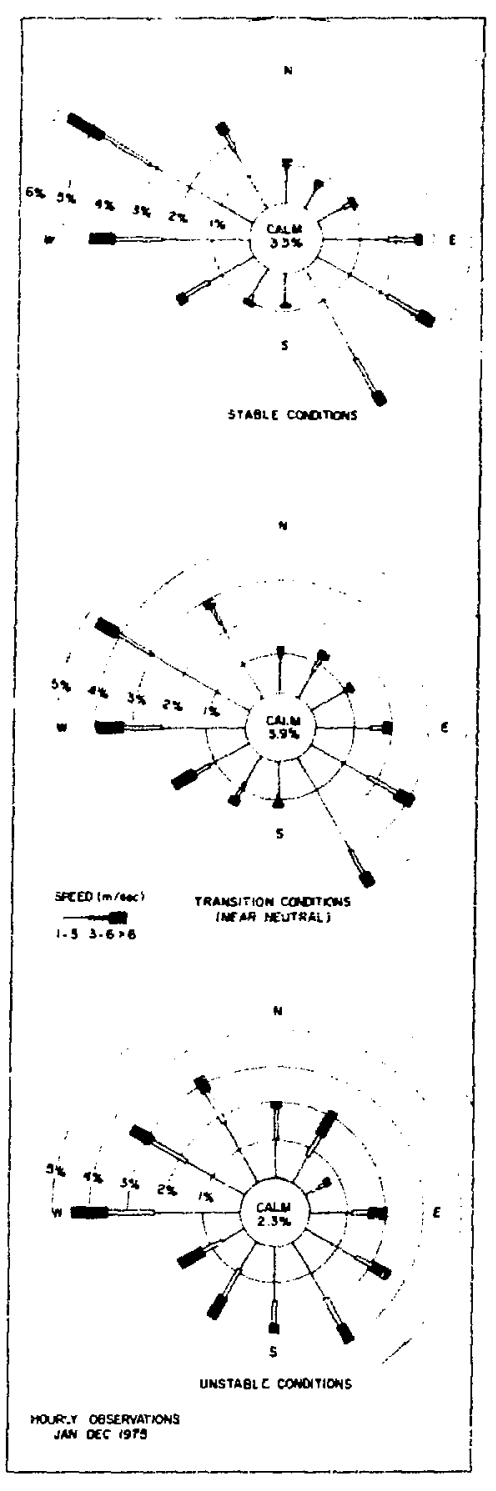

Fig. 3. 1975 wind roses.
Building in TA-3. Extension to other sites must be made with extreme caution because of terrain variability and the previously observed dependence of winds on measurement sites.

II. SUMMARY OF RESULTS

This report summarizes the results of LASL's enviromental monitoring program. Results of measurements of (I) radioactivity in air, ground and surface waters, sediments and soils, and foodstuffs, (2) external penetrating radiation, (3) chenical quality of surface and ground waters, (4) the chemical and radiochemical qualjty of potable supply waters, and (5) related ecolorical investigations are presented. The res its of the environmental inonitoring program for this reporting period confirm the generaily low radiation and contaminant levis due to IASL operations previously observed ${ }^{5}$ in the Los Alasios environs.

Average exterial penetrating radiation levels for off-site, perimeter, and on-site locations were 124,134 , and $211 \mathrm{mrem} / \mathrm{yr}$, respectively. Average concentrations of atmespheric tritium oxide for off-site, perimeter, and on-site locetions were $20,4 \hat{2}$, and $104 \times 10^{-12} \mu \mathrm{Ci} / \mathrm{m} \ell$, respectively. These concentrations are, respectively, 0.01, 0.02, and 0.002 of the applicable uncontrolledarea and controlled-area Concentration Guides (CGs). Atmospheric long-lived grossalpha and gross-beta activity concentrations in the LASL environs were 1.1 and $78 \times 10^{-15}$ $\mu \mathrm{Ci} / \mathrm{m} \ell$, respectively, or 2 and 0.38 of the

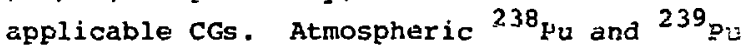
concentrations in the LASL environs were 0.6 and $21 \times 10^{-18} \mathrm{\mu Ci} / \mathrm{m} \ell$, respectively, which are 0.001 and 0.048 of the appropriate CGs. Atmospheric uranium concentrations were found to be $0.04 \mathrm{ng} / \mathrm{m}^{3}$ in the LASi ervirons, 0. vuuss of the cG.

Radioactivity in surface and ground waters in the LASL enviroris was below applicable Concentration Guides. The chemical quality of most surface and ground water samples in the LASL environs met standaras 
set for drinking water. The chemical quality of municipal and Laboratory sewage effluent samples is typical for such release areas, and these releases do not become a source of the potable water. The samples of porable sipply water were found to meet applicable standards for all chemica] and radiochemical constituents measured except arsenic. Water from one supply well was determined to have natural arsenic concentrations that exceeded the Environmental. Protection Agency (EPA) drinking water standard, and use of the well has been suspended pending special studies (see section $\mathrm{XI}, \mathrm{B})$.

No Laboratory-related concentrations of radionuclides were detected heyond a $20-\mathrm{km}$ radius of the Laboratory. Consequent$1 y$, individ lal and population dose assessments were made for Los Alamos county only. The only whole-body dose that could be attributed to the Laboratory was from tritiated water vapor. The maximum individual whole-body dose at a site boundary (near TA-33) was calculated to be $0.34 \mathrm{mrem}$, which is 0.068 of the individual dose Iimit of 500 mrem/yr for uncontrolled areas. The maximum dose at an occupied location occurred at the Los Alamos Airport, where the calculated whole-body dose was 0.18 mrem, 0.036 of the individual dose limit and 0.118 of the population dose limit of 170 mrem/yr. The tritiated water vapor contrioutes a total population dose of approximately 0.42 man-lem to the residents of Los Alamos county. The maximum lung dose from airborne transuranic nuclides was calculated to be 0.062 mrem (at TA-6) which is 0.0048 of the individual dose limit.

Related ecological investigations are also reported herein. The storm runoff of trace-level plutonium in a LASL canyon system is described. Initial results are presenced for a sampling program for radionuclides in Rio Grande sedinents and fish. A study designed to characterize the longterm ecological behavior of exposure tu uranium is also described.
One inadvertent release of radioactive materials occurred on-site in 1975. In abnormal chemical reaction at the Central wast rreatment Plant at TA-50 (see Fig. 4) -aused about $3000 \ell$ of a contaminated 'iguid-sludge mixture to flow out of the building. All contamination was confined to an area of about $500 \mathrm{~m}^{2}$, including portions of a blacktop parking lot and driveway and an adjacent soil area. The entire area was inside a fenced technical site. The contamination involved mixed alpha-, beta-, and gamma-emitting radioisotopes with principal activities being due to ${ }^{238} \mathrm{P}_{1},{ }^{90} \mathrm{Sr}$, and ${ }^{137} \mathrm{Cs}$. All detectable contamination was successfuliy removed. Exposure pathway analysis indicated that measurable exposure to on- and off-site persunnel did not occur.

\section{STATEMENT OF PARTICULARS}

A. Geographic Cooldinate System and Access Control

All Los Alamos County and vicinity 10cations referenced in this report are ideintified by the LASL Cartesian coordinate system (see Fig. 4) which is standard throughout the Laboratory and completely independent of the U. S. Geological survey and the New Mexico state Survey coordinate systems. The major coordinate markers shown on the maps are at $10000-\mathrm{ft}(3.048-\mathrm{km})$ interva1s, but for the purposes of this report, locations are identified to the nearest $1000 \mathrm{ft}$ $(0.30 \mathrm{~km})$. The area within the IASI boundary (see Figs. 1 and 4 ) is considered a controlled area in that the Laboratory has the capability of complete access restriction. Complete control would be institutea. were it deemed necessary for any significant reason. Under normal circumstances, however, public access roads that traverse the Laboratory site are open to somuters and other travelers; no continuous occupancy of these areas is permitted. Access to individual Technical Areas is restricted for reasons of safery and stcurity. Sone of the more remute and $1 j$ t.tle-used regjons of the site are not actively controlled against 


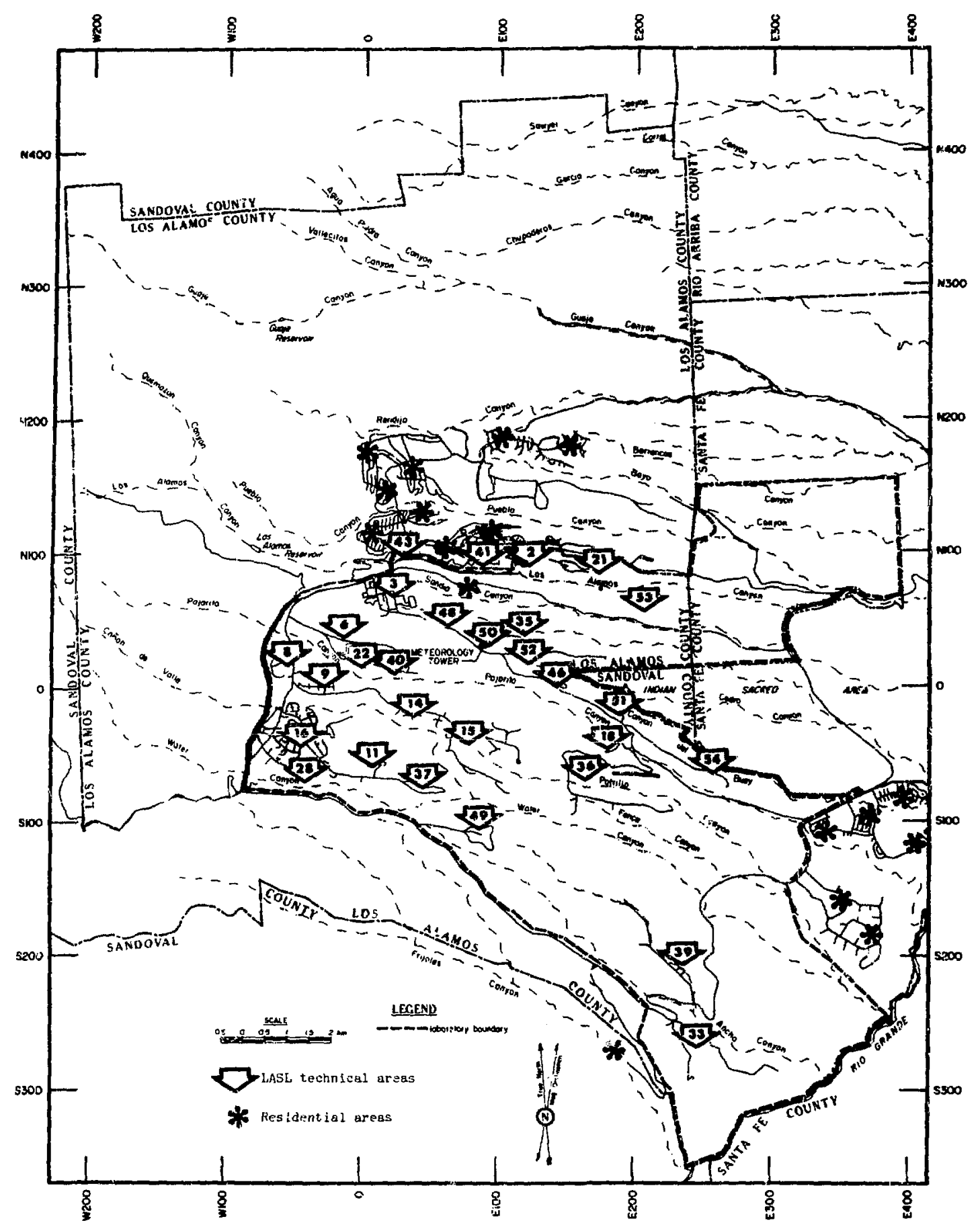

Fig. 4. Los Mlamos County residential areas and LASL technical areas. 
public access, although most of the site is posted against trespassing and routine security patrols cover the entire site.

B. Units of Measurement and Statistical

Treatment of Data

LASL scientific and technical documentation uses metric units, and conversion to the International System of Units (SI) is preferred wherever practicable. Table II provides conversion datá for units of measure given in this text.

For many environmental measurements, particularly those from wich a chemical or instrumental background must be subtracted, it is possitie to obtain net values that are lower than the minimum detection 1 imit (MDL) of the system (see Table III). It is not incommon for individual measurements to result in values of zero or negative numbers due to statistical fluctuations in the measurements. Although a negative value for an environmental measurement does not represent a physical reality, a valid long-term average of many measurements can be obtained only if the very small or negative values are includea in the population. For this reason, the primary value given in the numerical tabulations in this report is the actual value obtained from an indivijual. measurement or group of measurements. These primary values are those used in making subsequent statistical analyses and in evaluating the real environinental impact of Laboratory operations. To provide an indication of the precision anc accuracy of the numerical value, an additional value is included in parentheses immediately following the primary numerical value. For contiguous measurements, such as air monitoring and environmental radiation, the parenthetical value indicates the $95 \%$ confidence range for the primary value, i.e., twice the square root of the variance, or 20 . For discrete data, e.g., water samples, soil samples, etc., the parenthetical value represents twice the standard deviation of the distribution of observed values.
It has beon observed that some environmental data are not well described by the Gaussian distribution function. However, the logarithms of the data quite often fit the Gausgian functiors. Therefore, the lognormal probability distribution is used in describing some of the environmental data reported. It is inrended that use of the geometric mean and standard deviation parameters will teil more about the data than would the conventional arithmetic mean and standard deviation. An explantion of lognormal analysis was given in "Environmental Surveillance at Los Alamos during 1973."6 C. Standards for Environmental Contaminants

The concentrations of radioactive and chemical contaminants in air und water samples collected throughout the environment are compared with the standards contained in the regulations of several Federal and state agencies to verify the compliance of the Laboratory with all pertinent standards. IASL operations pertaining to environmental quality control are conducted in accordance with the directives and procedures contained in ERDAM 0500, Health and Safety, Chapters 0510, 0511, 0513, 0524, and 0550 .

In the case of radioactive materials in the environment, the standards contained in ERDAM 0524 (see Table IV) take precedence over other Federal or State regulations. However, the ERDA standard for uranium in water $(1500$ anc $60 \mathrm{mg} / \mathrm{l}$ for controlled and uncontrolled areas, respectively) does not consider chemical toxicity. therefore, for the purposes of this report the more restrictive standards ${ }^{7}$ of the International Commission on Radiological Protection (ICRP) for uranium in water of $60 \mathrm{mg} / \mathrm{l}$ for an occupational 40-h week, and $1.8 \mathrm{mg} / \mathrm{l}$ for a nonoccupational 168-h week, are preferred. For atmospheric uranium, the ERDA and ICRP standaxds are in agreement. For chemical pollutants, the controlling standards are those promulgated by either the EPA or the appropriate New Mexico State agencies (Table V). 
D. Analytical Quality Control Program

In order to ascertain the guality of the analytical capabilities supporting the environmental programs reported herein, a rigorous laboratory quality control program is maintained. A detailed presentation of both interlaboratory and intralaboratory quality control data is included to provide the reader with the necessary information with which to judge this laboratory and the environmental report.

Qualjty control for gross-alpha, grossbeta. ${ }^{137} \mathrm{cs}$, and tritium analyses has consisted of participation in the EPA laboratory intersomparison prozram. The EPA routinely presents the results of the intercorparison studies to the environmencal analytical laboratory. As a measure of procedural accuracy, the EPA graphically reports the normalized deviation of the mean of three reported values from the krown value. The precision of an anaiytical procedure is measured from a graphical presentation of the normalized range of the three repcrted results. To provide a ineans of evaluating laboratory results, the EPA includes a warning level (WL) and a control level (CL) on the graphs. The warning level is $2 \sigma^{\prime}$ twice the standard deviation (sta dev) of the mean, or $\bar{R}+2 \sigma_{R}$, the mean ranye plus 2 std dev of the range. The cuntrol limit for the normalized deviation of the mean i.s $3 \sigma_{\mathrm{M}}$, and for the range is $\overline{\mathrm{R}}+2 \sigma_{\mathrm{R}}$. values that fall above or below $C L$ indicate serious problems with the analysis. A de-tailed discussion of the EPA program may be found in "Environmental Radioactivity" Laboracory Intercomparison studies Program, 2975." 8

Group H-8 analytical laboratory performance during 1974 and 1975 for analyses of tritium, gross-beta, and ${ }^{137} \mathrm{Cs}$ in water is represented by the resulis shown in Figs. 5, 6, and 7 . The more recent resul.ts show that these procedures are currently providing satisfactory results. However, these is an indication of problems with each of the analyses during 1975. Causes of the gross-beta and tritium excursions beyond the control limits could not be attributed to any specific problem. However, the extremely high results for ${ }^{137} \mathrm{Cs}$ in December 1974 were apparently associated with problems in the NaI (TI) detection system, since extremely low results were obtained upon changing to the Ge(Li) detector system in the early months of 1975. The inaccuracy of reaults from the Ge(Li) system could be attributed to an inaccurate standard. The results improved after preparation of new standards in June 1975.

An internal quality centrol program for more complicated routine analyses was begun in October 3975. The program consists of analyzing control samples in conjuncticn with routine samples submitted to the laboratory. Control simples consist of blanks, i.e., materials containing none or 'Ery little of the subject material, and blank plus known quantities of the element or isotope of interest. Various blanks are available so that a slank matrix can be selected which corresponds to the matrix material of the companion samples.

Three parameters are calculated to evaluate the performance of the procedure: (1) the accuracy is judged from

Recovery $=\frac{\text { Reported Quantity } \times 100}{\text { Known Quantity }} ;$

(2) the precision is evaluated from calculation of twice the percentage stanjard deviation from the mean of replicate control samples

$$
20=\frac{200 \sqrt{\sum(\mathrm{X}-\overline{\mathrm{X}})^{2}}}{(\mathrm{~N}-1) \overline{\mathrm{X}}} ;
$$

(3) the quantity of element or isotope introduced during the analysis is evaluated from the absolute quantity in the unspiked blanks.

Approximately 10-15\% of the samples analyzed in the environmental analytical laboratory are control samples. The parameters discussed below are calculated for 


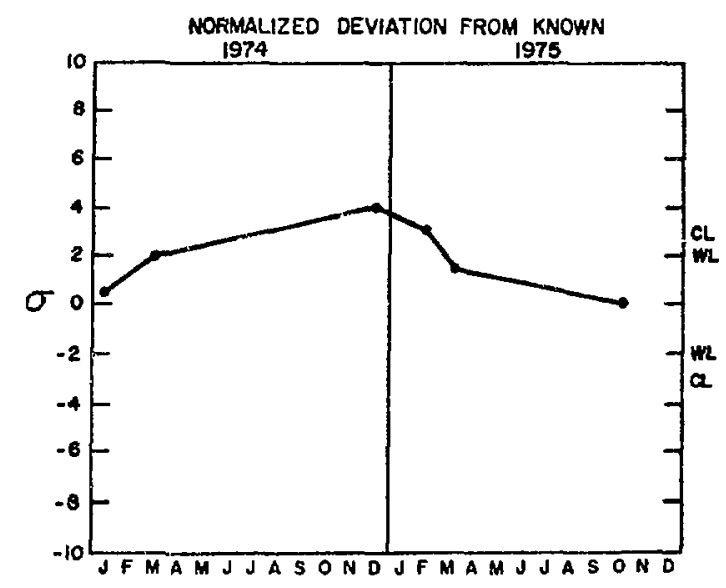

1974 NORMALIZED RANGE

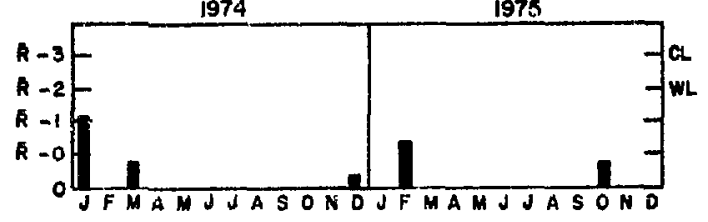

Fig. 5. Tritium in water crosscheck program.

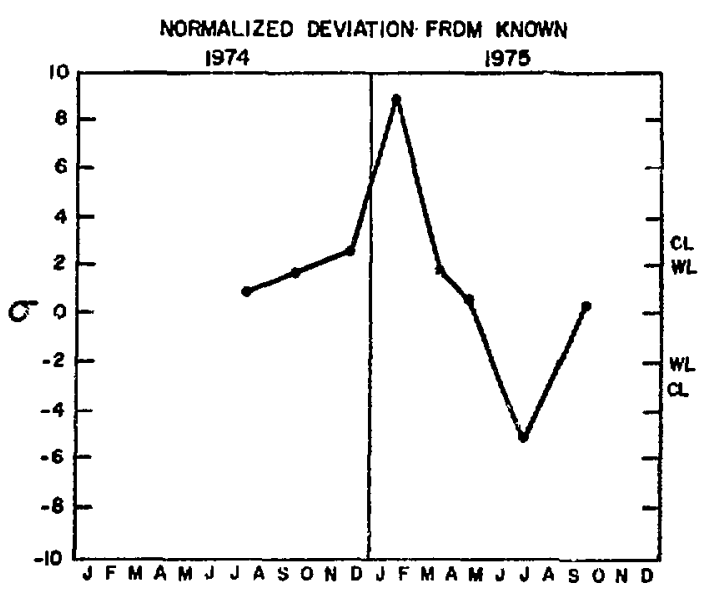

NORMALIZED RANGE

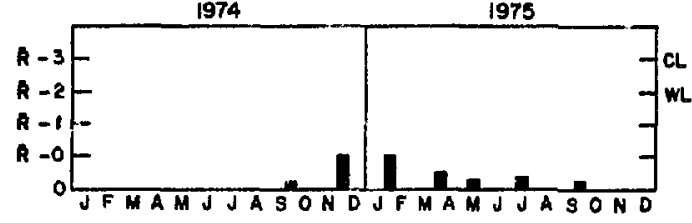

Fig. 6. Gross-beta in water crosscheck program.
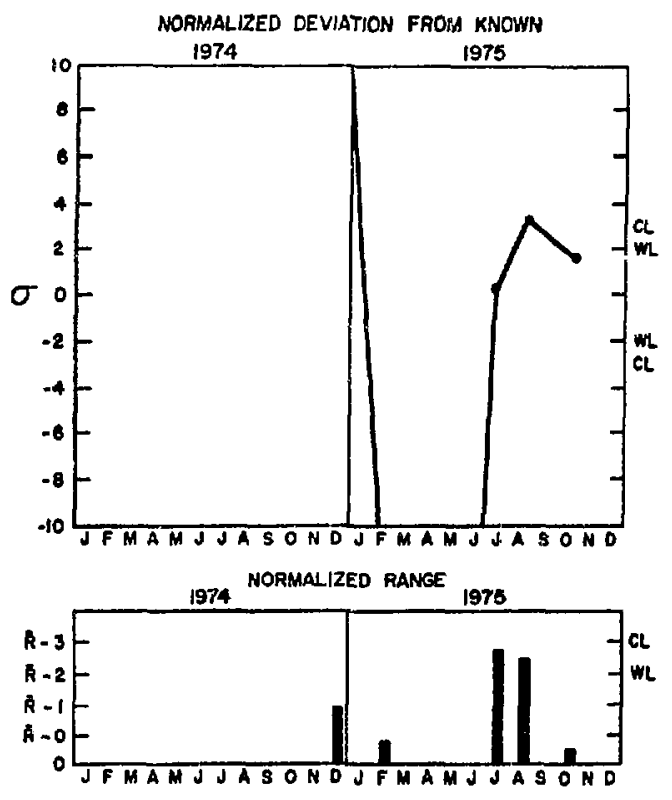

Fig. 7. Cesium-137 in water crosscheck program. 
controls that were included with each set of samples and forwarded to the person who submitted the samples. The results for all the controls are tabulated and reported periodically. These tabulations include the mean value for each parameter, twice the standard deviation as a measure of the population distribution and the number of results $N$ included in the tabulation. Quality control data for $238,239 \mathrm{Pu}$ analyses on a variety of matrices are

\begin{tabular}{|c|c|c|c|}
\hline Recovery $(239 \mathrm{Pu})$ & $\frac{N}{30}$ & $\frac{\bar{x}}{998}$ & $\frac{20}{428}$ \\
\hline $82 \sigma$ from Mean & 6 & 378 & 538 \\
\hline d (blank) & 36 & 0.0027 & 0.0026 \\
\hline$C_{i}{ }^{238} \mathrm{pu}$ (blank) & 75 & -0.0006 & 0.019 \\
\hline
\end{tabular}

The large $2 \sigma$ associated with each of the quantities reflects very large excursions in about 108 of the samples, rather than a large scatter in the distribution for the entire population.

A quality control program has not yet been initiated for analysis of ${ }^{241} \mathrm{Am}$.

Analytical capabilities for analyses of uranium in geologic materials were evaluated by running standardized fly ash from the luational Bureau of Standards (NBS) and standardized samples of pitchblend from the International Atomic Energy Agency (IAEA). Triplicate sets of these standard materials were analyzed $s i x$ times to evaluate the capabilities of the procedure. This is not the same as including control samples rou$t$ inely with normal sample analysis. The quality control data for uranium analysis in şeologic materials is

$\begin{array}{lrrr} & \frac{N}{8} & \frac{\bar{X}}{20} & \frac{20}{218} \\ 8 \text { Recovery } & 18 & 1058 & \text { Mean of Replicates } \\ \text { Interferences to this procedure from }\end{array}$
nine common metals were evaluated as well as the effect of variations in several critical steps in the procedure. A LASL report describing the uranium fluorometric procedure and the results of the evaluation is in preparation.

A quality control program for the analysis of arsenic in water by atomic absorption spectrophotometry has recently been initiated. In addition to the normal quality control program, other procedures were used to evaluate arsenic. Atomic absorption analysis standard additions and dilutions were performed on replicate samples from the Los Alamos well water system. The $\& 2 \sigma$ from the mean of these replicates was calculated to evaluate the reproducibility of the results measured at various arsenic concentrations. Selected samples of these waters were analyzed by radiochemical neutron activation analysis and by atomic absorption spectrophotcmetry, and the results obtained by the different methods were compared. The of 20 from the mean arsenic concentrations determined by the two methods is reported below along with the other quality control data for the arsenic procedure.

\& Recovery

$82 \sigma$ from Mean of Replisates $45 \% \quad 98$

820 from Mean of Replicates $10 \quad 12 \% \quad 228$ (Standard Addition \& Dilution)

$\& 2 \sigma$ from Mean of Duplicates $15 \quad 7 \%$ (RNAA and $A A$ ) a

ppb As (tap water) D

$3 \quad 4.3 \quad 0.5$

aNAA, radiochemical neutron activation analysis; AA, atomic absorption spectrophotometry.

$b_{\text {Assumed to be actual concentration in tap }}$ water.

IV. NVIRONMENTAL RELEASES FROM LASL OPERATIONS

LASL's activities are carried out in 30 active technical areas (TA) distributed over the IASI site (Fig. 4). These facilities include hundreds of potential sources of waste effluent; however, processes with potential for significant releases are confined to only a few locations which are xigorously controlled and monitored.

The environmental monitoring program emphases are dictated by the types and quantities of potentially hazardous materials being used in LASL programs and by the 
demography, ecology, hydrolegy, and geology of this location. Emphasis is placed on the analyses for tritium, uranium, and plutonium in samples of the environmental media; fission product radionuclides are of leaser concern, due to the minimal amounts handled. Selected samples are analyzed for radioactive species of cesium.

The documented release of radioactive materials to the atmosphere from LASL operations is shown in Table VI. These data were compiled from stack effluent monltoring determinations and represent no significant change from effluents documented in $\mathrm{CY} 74 .^{5}$

\section{EXTERNAL PENETRATING RADIATION \\ A. Procedureg}

Exposure from external penetrating radiation (primarily gamma radiation) in the LASL environs is monitored by 44 thermoluminescent dosimeter (ILD) stations, 11 of which are located along the perimeter of the Laboratory (within about $1 / 2 \mathrm{~km}$ of the boundary), 12 are located beyond the Laboratory boundaries, and 21 are located onsite and in the immediate vicinities of LASL nuclear facilities. (Locations are given in Fig. 8, and map coordinates identify locations in the data tabulation; see Table VII.) A group of 27 stations, on a 4-wk integration cycle, covers normal LASL and Los Alamos County locations in addition to the nuclear facilities. A second group consisting of 17 stations, on a 13-wk integration cycle, includes Espanola, Pojoaque, Santa Fe, Pajarito Ski area, and the remainiasg LASL and Log Alamos county locations. All of the 26 air sampling stations serve as TLD stations. The TLD monitoring locations were selected to reduce systematic radiation differences caused by variations in natural background radiatıon.

Each of the TLD monitors consists of three Harshaw TLD-100 $(\mathrm{B})$ LiF (natural 180topic composition) chips $6.4 \mathrm{~mm}$ square by $0.9 \mathrm{~mm}$ thick. The TLDs are annealed, calibrated, and read by standard techniques.
The annealing cycle is 2 h at $673 \mathrm{~K}$, followed by $1 \mathrm{~h}$ at $373 \mathrm{~K}$. For each annealing batch, an independent calibration factor is determined by standard radiation (from $10 \mathrm{mR}$ to $160 \mathrm{mR}$ ) with ${ }^{60} \mathrm{Co}$. The chips are heatsealed in an opaque polyethylene envelope which is sealed in an opaque 7-me polyethylens vial for placement in the field. Latent thermoluminescence after annealing and transit dose are compensated for by control dosimeters. All TLDs are read with an Eberline model TLR-5 reader with $15-\mathrm{s}, 413 \mathrm{~K}$ preheat and $15-9,513 \mathrm{~K}$ integration cycles. All handling operations are conducted under "dark" conditions. As the TLDs are calibrated in $m R$, a conversion factor of 1 rem (tissue) $=1.061 \mathrm{R}$ is used. ${ }^{9}$

B. Results

The annual external penetrating raciation dose values determined from the TLD environmental radiation monitoring program are summarized in Table VII according to off-site, perimeter, and on-site locations. The values are the total dose integrals for 1975 for each station. Parenthetical values represent twice the square root of the variance of the integrals, i.e., the 20958 confidence interval. The annual dose variance is the sum of the variances of the individual monthly or quarterly dose measurements and is not related to the temporal varlations of the individual dose measurements. Monthly and quarterly dose variances are derived from the distribution of the three individual TLD readings, the error of calibration, the control dosimeter corrections, and the instrumental background subtractions.

Temporal variations in environmental gamma radiation were generally less than 508. However, significant epatial variations were observed which result from differences in the terrestrial component of external environmental gamma radiation. These differences are a complex function of the topography, geology, hydrology, and meteorology of the monitoring sites. Due to atmospheric shielding of cosmic radiation, 


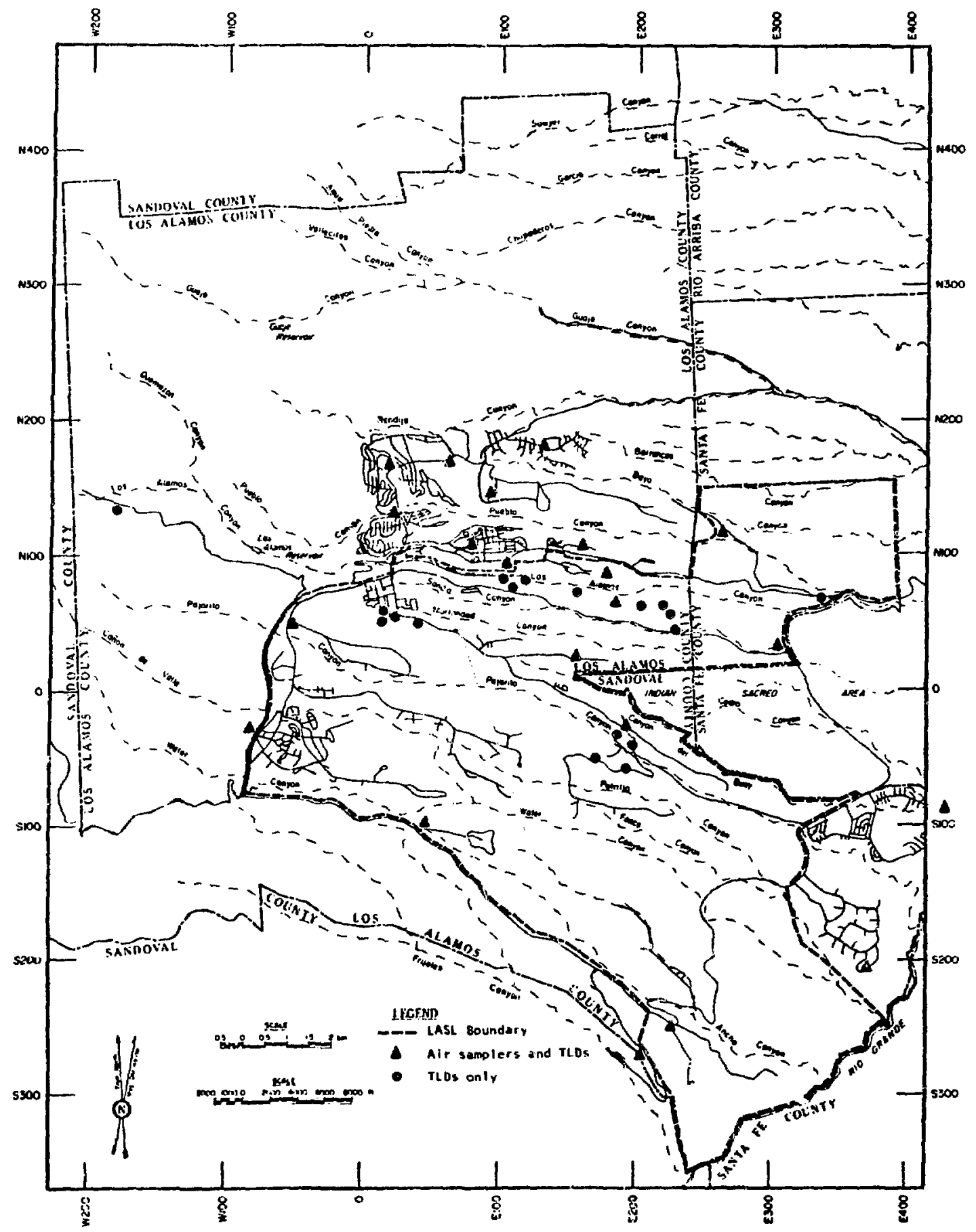

Fig. 8, TLD and air sampler locations. 
elevation is also a factor in natural radiation levels. As would be expected, the lower monitoring locations, e.g., Espanola, Pojoaque, and Pajarito Acres, recorā the smallest dose rates. A linear relationship between elevation and dose can be assumed for the range of elevations encountered, whereby dose and elevation are found to have a linear correlation coefficient $r$ of 0.52 $(P \approx 0.01)$ for a sample of 23 background locations. The relatively poor correlation results from the aforementioned variations in terrestrial radiation, which remain unaccounted for by this simple linear fit. For those background stations on the Pajarito Plateau, the mean dose rate is about $130 \mathrm{mrem} / \mathrm{yr}$ with a standard deviation of 11 mrem/yr. The terrestrial component of environmental radiation for New Mexico has been estimated 10,11 to be 40 to $70 \mathrm{mrem} / \mathrm{Yr}$. Thus, approximately 608 of the total environmental gamma-ray dose in the LASL environs is of cosmic origin.

There was no LASL-related dose indicated for any of the off-site environmental dosimeter stations. The perimeter station \#16, located in a LASL controlled area, has an anomalous dose rate which is believed to result from an isolated region of trace radionuclide contamination associated with stream runoff and alluvial movement in the LASL effluent receiving canyon. The arithmetic mean and standard deviation of the off-site and perimeter dose values were 124 \pm 17 and $134 \pm 24 \mathrm{mrem} / \mathrm{yr}$, respectively. An arithmetic mean is not considered the best description for on-site doses because the on-site locations at TA-2 (Omega West Reactor), TA-3 (Van de Graaff Facili$t y$ ), TA-18 (criticality experiments), and TA-53 (LOs Alamos Meson Physics Facility) are special monitoring sites designed to chronicle the levels of direct radiation resulting from LASL nuclear facilities. These monitors, e.g., TA-53 (D), TA-3 (A), and TA-18. (C), are as close as $0.3 \mathrm{~km}$ to radiation sources and record doses of up to an order of magnitude greater than background rates. Because of these special 10cations, the distribution of all 44 doserate values is asymmetrical, thus, the geometric mean and standard geometric deviation of $166 \mathrm{mrem} / \mathrm{yr}, \sigma_{\mathrm{g}}=1.48$, best describe the total assemblage of dose-rate data.

\section{RADIOACTIVITY IN AIR}

\section{A. Sampling Procedures}

Atmospheric radioactivity samples were collected at 26 continuously operating air sampling stations in Los Alamos County and vicinity. Station locations are shown in Fig. 8 and map coordinates identify locations in the data tabulations. Samples were collected over 2-wk periods for a total of 676 samples for CY 75. "Hi-Vol" air pumps with flow rates of approximately $3 \mathrm{l} / \mathrm{s}$ were used in the network. The atmospheric aerosol was collected on a 79-mm-diam polystyrene filter. A fraction of the total air flow (approximately $2 \mathrm{ml} / \mathrm{s}$ ) was passed in parallel through a cartridge containing silica gel adsorbent which collects atmospheric water vapor for tritium analysis. Air flow rates through both sampling cartridges were mor itored with variable-area flow meters, and sampling times were recorded with electric clocks.

Table IV contains listing of Concentration Guides (CGs) for several radioactive species in air and water for uncontrolled and controlled areas. Referring to Fig. 8 and Tables IX through XII, monitoring stations 1 through $12,14,17,20$, and 21 are outside the LASL boundary, and concentrations for these locations are compered to CGs for uncontrolled areas. All other stations are within the LASL boundary where the CGs for controlled areas apply (see Section III.A). Table VIII summarizes the results of the atmospheric radioactivity monitoring program for $c y 75$.

B. Daily Radioactivity

Atmospheric radioactivity samples were collected daily at TA-3 (N5OE40) with a 
"Hi-Vol" sampler similar to those used in the biweekly sampling. The daily atmospheric aerosol filter was counted for grossalpha and gross-beta activities on the day of collection and again 7 to 10 days after collection. The first measurement could provicie an early indication of a major change in general atmospheric radioactivity levels. The data from the second measurement were used to observe temporal variations in long-lived atmospheric radioactivity.

Atmospheric gross-beta concentrations for 1975 are shown in Fig. 9. Because the daily concentrations are approximately lognormally distributed in time, geometric averaging is appropriate. The smoothed data of Fig. 9 represent the geometric means of daily concentration values for each week of 1975. Temporal variation of these data is typical for gross-beta activity arising from stratospheric fallout and natural phenomena.

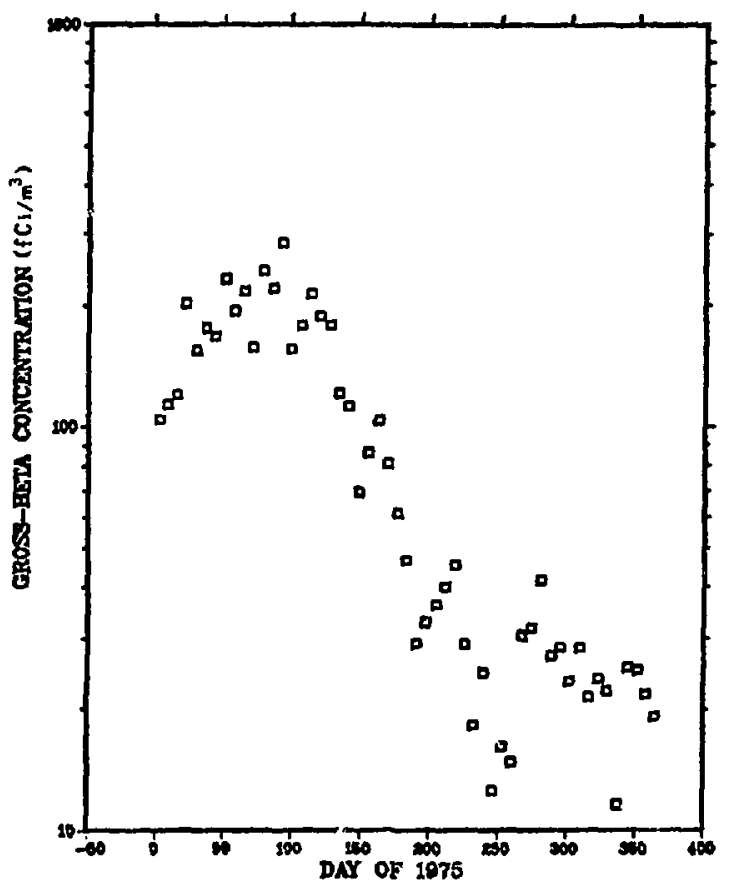

Fig. 9. Atmospheric gross-beta radioactivity for 1975 .
The highest gross-beta concentration, observed on $19 \mathrm{March}$, was $1475 \times 10^{-15} \mu \mathrm{Ci} / \mathrm{m} \ell$. These data did not show evidence of radioactivity from foreign atmospheric nuclear tests during the year.

\section{c. Tritium}

Silica gel cartridges from the 26 air sampling stations were analyzed biweekly for tritiated water. Water was distilled from each silica gel sample, giving a 2-wk average atmospheric water sample. A standard aliquot of the distillate was analyzed for tritiun by liquid scintillation counting. The resultant tritium concentration was then multiplied by the measured absolute humidity to give the $2-w k$ average tritiated water vapor concentration in air.

The 2-wk concentrations for each station were averaged for $C Y 75$ and are presented in Table IX. Parenthetical values represent twice the propagated measurement errors, i.e., 20 associated with the annual averages. The variance $\left(\sigma^{2}\right)$ for the annual concentration is the sum of the variation measurements divided by the square of the number of measurements, and is not related to the temporal distribution of the individual measurements. Biweekly concentration variances are derived from nuclear counting statistics, air sample volume uncertainties, instrumental uncertainties, etc. The data of Table IX are grouped according to offsite, perimeter, and on-site sampling locations. Minimum values are not presented because they generally did not exceed the MDL for the analysis. The highest observed annual concentration for an uncontrolled area (Los Alamos Airport) was $88 \times 10^{-12}$ $\mu \mathrm{Ci} / \mathrm{ml}$, and for a controlled area the $\mathrm{high-}$ est value was $174 \times 10^{-12} \mu \mathrm{Ci} / \mathrm{m} l$ measured at TA-52. These concentrations are respectively 0.048 and 0.0038 of the uncontrolledarea and controlled-area CGs specified for tritium in air. The tritium concentrations eported herein, as well as the CGs, are for itmospheric tritium oxide (HTO). The arithmetic mean and arithmetic standard deviation for the distributions of off-site, perimeter, 
and on-site annual average tritium concentrations are $20 \pm 6,42 \pm 24$, and $104 \pm 57$ $x 10^{-12} \mu \mathrm{Ci} / \mathrm{m} \ell$, respectively. The atmospheric tritium oxide data are not characterized by a typical Gaussian curve but are distributed asymetrically toward the higher values. This, a log-normal treerment is applicable. The geometric mean and geometric standard deviation for these three distributions are 19, 1.3; 37, 1.8; and $92 \times$ $10^{-12} \mu \mathrm{Ci} / \mathrm{ml}, 1.7$; respectively. For the stations on the Pajarito Plateau, LASLrelated tritium releases generally obscure any temporal variations in synoptic atmospheric tritium-oxide concentration.

D. Gross Radioactivity

Gross-alpha and gross-beta activities on the biweekly air filters were measured with a gas-flow proportional counter on the first and tenth day after collection. The first count was used to screen the samples for incrdinate levels of activity. The second count, free from the activity of adsorbed radon and thoron daughters, provided a record of long-lived atmospheric radioactivity. The annual average biweekly gross-alpha and gross-beta activity concentrations are presented in Table $x$. Parenthetical values represent twice the propagated measurement errors, i.e., $2 \sigma$, associated with the annual averages. (See atmospheric tritium section for error explanations.)

The data are grouped according to offsite, perimeter, and on-site sampling locations. For gross-alpha rctivity, the 26 annual average concentrations are normally distributed around an arithmetic mean of $1.1 \times 10^{-15} \mu \mathrm{Ci} / \mathrm{ml}$ and have a standard deviation of $0.1 \times 10^{-15} \mu \mathrm{Ci} / \mathrm{ml}$. The highest average gross-alpha concentration, $1.2 \mathrm{x}$ $10^{-15} \mu \mathrm{Ci} / \mathrm{ml}$, is 28 of the CG for a controlled area. For the gross-beta activity, the 26 annual average concentrations fit a normal distribution with an arithmetic mean and standard deviation of $78 \pm 4 \times 10^{-15}$ $\mu \mathrm{Ci} / \mathrm{ml}$. The highest observed annual concentration of $86 \times 10^{-15} \mathrm{\mu Ci} / \mathrm{ml}$ (at Bandelier
Lookout) is 0.38 of the CG for an uncontro:led area. Significant temporal variations in long-1ived gross-alpha and grose-beta concentrations were observed, typical for North America and representing seasonal phenomena and mixing of stratospheric nuclear debris into the troposphere. Grose-beta concentrations varied by as much as a factor of 16, with the maximum escurring around late March and the minimum around early September (cf. Fig. 9).

E. Plutonium and Americium After being neasured for grose-alpha and gross-beta ; tivities, the biweekly filters for each ation were combined and dissolved to produce composite 6 - or 8-kk samples for each station. An aliquot of each sample was saved for urantum analyeis, and plutonium was separated by anton exchange from the remaining solution. For 11 selected stations, the eluent solutions from the plutonium separation were combined to represent 12- or 14-wk iamples. For each of the 11 stations, americium was then separated from three 1/4-yr composite samples via cation exchange. The purified plutonium and anericium samples were separately electro-deposited and measured for alphaparticle emission with a solid-state alpha detection system. Alpha-particle energy groups associated with the decay of ${ }^{238} \mathrm{Pu}$, ${ }^{239} \mathrm{Pu}$, and ${ }^{241} \mathrm{Am}$ were then integrated, and the concentration of each radionuclide in its respective air sample was calculated. This technique does not differentlate between $239 \mathrm{Pu}$ and $240 \mathrm{Pu}$.

The annual average ${ }^{238} \mathrm{Pu}$ and ${ }^{239} \mathrm{Pu}$ concentrations for each station are listed in Tabie XI according to off-site, perimeter and on-site sampling locations. The averages are time-weighted, and parenthetical values represent twice the propagated measurement $\epsilon$-rors, i.e., 20, associated with the annual averages. The varlance $\sigma^{2}$ for the annual concentration is the sum of the variances of the individual 6- or 8-wk concentration measurements divided by the 
square of the sumber of measurements. Sixor 8-wh concentration variances are derived from nuclear counting statisícs, air sample volume uncertainties, etc. Minimum values are not presented in Table XI as they generally did not exceed the MDL for the anal$y$ sis. The highest observed annual ${ }^{238_{\mathrm{Pu}}}$ concentration for an incontrolled area (Fuller Lodge) was $2.3 \times 1 n^{-18} \mu \mathrm{Ci} / \mathrm{ml}$, and for a controlled area was $1.6 \times 10^{-18} \mathrm{uCi} /$ m $\ell$ measured at TA-6. These concentrations are, respectively, 0.0038 and 0.00018 of the CGs specified for ${ }^{238} \mathrm{Pu}$ in air. For ${ }^{239} \mathrm{Pu}$, the highest observed annual concentration for an uncontrolled area (Fuller Lodge) was $29 \times 10^{-18} \mathrm{\mu Ci} / \mathrm{ml}$, and for a controlled aren the highest value was $53 \mathrm{x}$ $10^{-18} \mathrm{\mu Ci} / \mathrm{ml}$ at $\mathrm{TA}$. These concentrations are, respectively, '.058 and 0.0038 of the CGs specified for ${ }^{239} \mathrm{Pu}$ in air. The ${ }^{239} \mathrm{Pu}$ annual concentration value for the TA-6 station deviates from the normal range of values. This average is erratic because of the maximum measurement of $317 \times 10^{-i 8} \mathrm{uci} /$ $\mathrm{m} \ell$ observed in July. The July value is believed to be unrealistic since a release and dispersion of ${ }^{239} \mathrm{Pu}$ from the Laboratory would most likely be noted at several stations. The high value for this sample is probably due to cross-contamination in the chemistry laboratory. F nee the datum could not be unequivocably discredited, it was inrluded in this compilation. The arithmetic mean and arithmetic standard deviation for the distributions of off-site, perimeter, and on-site annual average ${ }^{238} \mathrm{Pu}$ concentrations are $0.8 \pm 0.6,0.6 \pm 0.5$, and $0.5 \pm$ $0.4 \times 10^{-18} \mu \mathrm{Ci} / \mathrm{ml}$, respectively. For $239 \mathrm{Pu}$. the arithmetic mean and arithmetic standard deviation for the distributions of of $f-$ site, ferimeter, and on-site annual average concentrations are $20 \pm 4,24 \pm 10$, and 20 $\pm 2 \times 10^{-18} \mathrm{uCi} / \mathrm{ml}$, respectively. These data do not sugqest statistically significant spatial variations for plutonium concentrations.

Significant temporal variations in atmospheric plutonium concentrations were ob- served during 1975. These variations closely parallel the pattern manifest in the dally long-lived (fallout) gross-beta concentrations shown in Fig. 9. For ${ }^{239} \mathrm{pu}$, the maximum concentrations occurred in April with an all-station average of about $44 \mathrm{x}$ $10^{-18} \mu \mathrm{Ci}$ ime. The minimum, observed during August and September, had an all-station average of about $4 \times 10^{-18} \mathrm{HCi} / \mathrm{ml}$. The ${ }^{239} \mathrm{Pu}$ all-station averages for the eight periods of CY 1975 (excluding the one erratic value for station 15) were compared to the grosg-beta all-station averages representing the same time periods. The data were found to be highly correlated with a linear correlation coefficient $r$ of +0.90 $(N=B, P=0.002)$. The correlation between gross-beta concentration and ${ }^{238} \mathrm{Pu}$ concentration was far less conclusive ( $r=+0.58$ ) primarily because of the inherent analytical uncertainty in the ${ }^{238} \mathrm{Pu}$ data. Nevertheless, the same general chronological pattern was indicated. These correlations of seasonal radioactivity imply that atmospheric plutonium in the IASL environs is at least in part from the synoptic injection of stratospheric nuclear debris into the troposphere. The ratio of ${ }^{239} \mathrm{Pu}$ to ${ }^{238} \mathrm{Pu}$ observed for all stations during $C Y 19 ; 5$ was $33 \pm 27$.

The annual average ${ }^{241_{A m}}$ concentrations for the 11 selected stations are also presented in Table XI. Not only are the data widely scattered, but the 20 errors associated with the concentrations are large. Hence, no attempt was made at statistical analysis. The highest observed annual average concentration of ${ }^{241} \mathrm{Am}$ (observed at Los Alamos Airport) was 0.018 of the CG for an uncontrolled area,

F. Uranium

A sample was composited for each of the 26 stations, with aliquots taken from the dissolution from the plutonium and americium procedure, to represent a 12- or 14-wk sampling period. The uranium content of the samples was determined by fluoromettric techniques, and quarterly atmospheric 
uranium concencrations were calculated. The 12- or 14-wk uranium concentrations for each station were averaged for $\mathrm{CY} 75$, and are presented in Table XII according to off-site, perimeter, and on-site sampling locations. The averages are time-weighted, and parenthetical values represent twice the propagated ercurs, i.e., 20, associated with the annual averages. The variance $\sigma^{2}$ for the annual concentration is the sum of the variances of the individual 12- or 14-wk concentration measurements divided by the square of the number of measurements, and is not related to the temporal distribution of the individual measurements. The 12- or 14-wk concentration variances are derived from instrumental uncertainties, air-sample volume uncertainties, etc. The fluorometric arialysis does not differentiate isotopes of uranium, and the annual average concentrations are thus given $i: 2 \mathrm{pg} / \mathrm{m}^{3}$. The highest observed annual uranium concentration for an uncontrolled area (Acorn street) was 97 $\mathrm{pg} / \mathrm{m}^{3}$, and for a controlled area the highest value was $72 \mathrm{pg} / \mathrm{m}^{3}$ measured at $\mathrm{TA}-52$. These concentrations are respectively 0.0018 and 0.000038 of the CGs specified for natural uranium in air. The arithmetic mean and arithmetic standard deviation for the distribution of off-site, perimeter, and onsite annual averige uranium concentrations are $45 \pm 20,37 \pm 21$, and $45 \pm 19 \mathrm{pg} / \mathrm{m}^{3}$, respectively. These average values are statistically indistinguishable.

VIT. RADIOACTIVITY IN SURFACE AND GROUND WATERS

Surface and ground water radioactility monitoring provides a routine surveillance of the potential dispersion of effluents from LAsL operations. Water samples are collected in 4- $\ell$ polyethylene bottles, acidified in the field with $5 \mathrm{~m}$ of concentrated nitric acid, and returned to the laboratory within a few hours for filtration through 0.45- $\mu \mathrm{m}$-pore membrane filters. The samples are analyzed radiochemically for dissolved plutonium ( $\left.{ }^{238_{\mathrm{Pu}} \text { and }}{ }^{239} \mathrm{Pu}\right)$ and tritium as
HTO, as well as for dissolved grose-alphe, -beta, and -gamma activities. solected

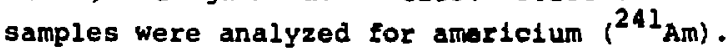
A fluorometric technique is used to messure total uranium concentrations.

A. On-Site Surface and Ground water: Radioactivity concentrations were determined for water samples from $s i x$ on-aite locations that are not Laboratory effluent release areas (Fig. 10, Table XIII). The maximum concentrations for these $81 x$ stations are

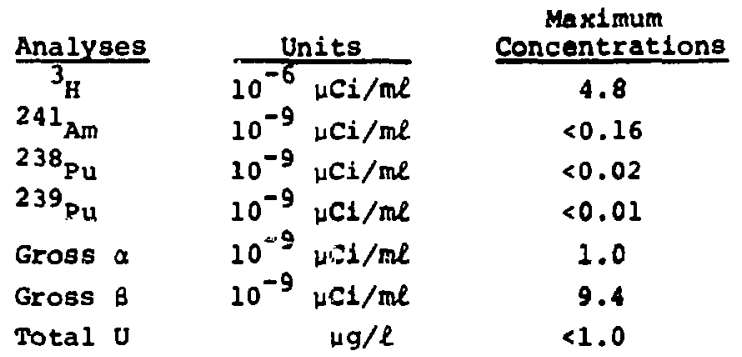

The radioactivity concentratione are near or below detection limits, and are of the same magnitude as reported for $1974 .^{5}$ The radioactivity concentrations for surface and ground waters were determined frum 22 locations in past and present Laboratory release areas (FIg. 10, Table XIII). The surface and ground waters in these areas are not a source of munleipal, induetrial, or agricultural supply, and do not reach the Rio Grande except during storm runoff. The maximum concentrations in these canyon waters are

\begin{tabular}{|c|c|c|c|c|c|}
\hline \multirow[b]{2}{*}{ Analyses } & \multirow[b]{2}{*}{$\begin{array}{c}\text { Unit } \\
(\mu \mathrm{Ci} \text { idgl })\end{array}$} & \multicolumn{4}{|c|}{ Canyon } \\
\hline & & Pueblo & Sandia & $\begin{array}{l}\text { DP-Las } \\
\text { Ilamos }\end{array}$ & $\begin{array}{l}\text { Mortan- } \\
\text { dad }\end{array}$ \\
\hline $\mathbf{3}_{\mathbf{H}}$ & $10^{-6}$ & 2.3 & 8.2 & 76 & 195 \\
\hline An & $10^{-9}$ & 1.2 & $<0.2$ & 0.4 & 1.1 \\
\hline${ }^{238} \mathrm{Pu}$ & $10^{-9}$ & 0.02 & $<0.02$ & 0.27 & 125 \\
\hline${ }^{239} \mathrm{Pu}$ & $10^{-9}$ & 0.34 & 0.01 & 0.84 & 3.6 \\
\hline Grosa a & $10^{-9}$ & 6.9 & 12 & 22 & 46 \\
\hline Gross B & $10^{-9}$ & 61 & 23 & 500 & 1400 \\
\hline Total U & $\mu g / \ell$ & 2.3 & 1.7 & 6.3 & 5.4 \\
\hline
\end{tabular}

The radioactivity concentratione observed in Acid-Pueblo Canyon result from residuals of effluent released into the canyon before 1964. Sandia Canyon receives cooling tower blowdown from the TA-3 power plant and some 


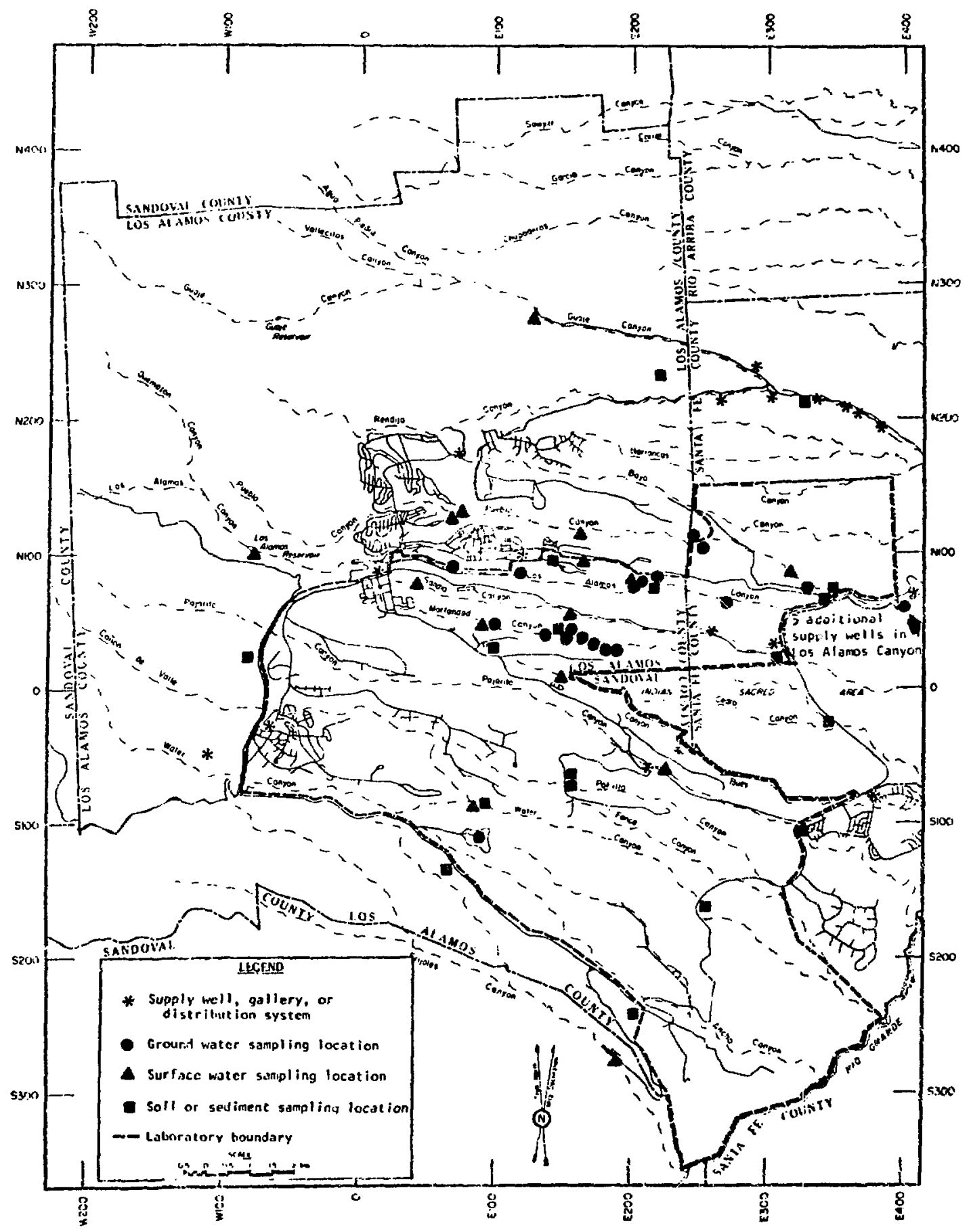

Fig. 10. Water, sediment, and soil sampling locations on or near the LASL site. 
treated sewage effluents. The mayimun concentrations in these canyons are low, at or near detection limits, and are about the same levels as reported for $1974 .^{5}$

The concentrations in DP-Los Alamos and Mortandad Canyons reflect concentrations from current release of effluents from the TA-21 and TA-50 industrial waste treatment plants, respectively. The maximum observed concentrations of ${ }^{3} \mathrm{H},{ }^{239} \mathrm{Pu}$, and gross-alpha and gross-beta activities increased from 1974 to 1975. The maximum observed concentration of ${ }^{238} \mathrm{Pu}$ decreased in DP-Los Alamos. The maximum observed concentration of ${ }^{238} \mathrm{Pu}$ in Mortandad increased ninefold frcm the previous reportinq period, reflecting recent ${ }^{238} \mathrm{Pu}$ additions to the canyon. As observed in the past, the concentrations of radiom nuclides decreased with distance from the effluent outfalls. The maximum observed concentrations were well below the cGs for uncontrolled areas (Table IV).

\section{B. Off-site and Supply Waters}

Regional surface waters within $75 \mathrm{~km}$ of LASL were sampled at six locations to ascertain normal levels of radioactivity in waters of the area (Fig. 11, Table XIV). Radioactivity concentrations were also determined for samples from six perineter surface and ground water stations located <5 $\mathrm{km}$ outside the LASL boundary, from $\$ 6$ wells and 1 gallery that furnish the water supply for Los Alamos, ana from 5 stations on the distribution system (Fig. 10, Table xIV) . The maximum observed radioactivity concentrations for these waters are

\begin{tabular}{|c|c|c|c|c|}
\hline Analyses & $\begin{array}{c}\text { Units } \\
(\mu \subset i / m 2)\end{array}$ & $\begin{array}{l}\text { Regional } \\
\text { Surface } \\
\text { Water } \\
\end{array}$ & $\begin{array}{l}\text { Peximeter } \\
\text { Surface and } \\
\text { Ground Water } \\
\end{array}$ & $\begin{array}{l}\text { Los } \\
\text { Alamos } \\
\text { Hatar } \\
\text { Supply }\end{array}$ \\
\hline${ }^{3} \mathrm{H}$ & $10^{-6}$ & 1.8 & 2.3 & 1.5 \\
\hline $238_{\mathrm{PL}}$ & $10^{-9}$ & $<0.15$ & $<0.10$ & $<0.06$ \\
\hline $239 \mathrm{PU}$ & $10^{-9}$ & $<0.04$ & 0.08 & 0.03 \\
\hline Gross a & $10^{-9}$ & 3.9 & 4.8 & 7.0 \\
\hline Gross B & $10^{-9}$ & 15.2 & 11 & 7.5 \\
\hline Total v & $\mu g / R$ & 2.9 & 10 & 17 \\
\hline
\end{tabular}

The concentrations of radioactivity are low, at or near the limits of detection. There has been no significant change in concentrations from those reported in 2974.5
VIII. RÄDIOACTIVITY IN SOILS AND SEDIMENTS Soil samples were collectea by taking five plugs, $75 \mathrm{~mm}$ in diameter and $50 \mathrm{~mm}$ deep, at the center and corners of a square area $10 \mathrm{~m}$ on a side. The five plugs were combined to form a composite sample for radiochemical analyses. Sediment samples were collected from dune build-up behind boulders in the main channels of perenially flowing streams. Samples from the beds of intermittently flowing streams were collected across the maln channel. The soil and sediment samples were analyzed for gross-alpha and gross-beta activities, total uranium, and ${ }^{238} \mathrm{Pu}$ and ${ }^{239} \mathrm{Pu}$. Moisture distilled from the soil samples was analyzed for ${ }^{3} \mathrm{H}$. Soil and sediment samples were collected in the same general locations as the regional water samples to provide data on the normal concentrations of radioactive materials in the environment beyond the range of possible influence by LASL operations (Fig. 11, Table XV). Samples were also collected at off-site, perimeter, and on-site stations (Fig. 10 and Table XV).

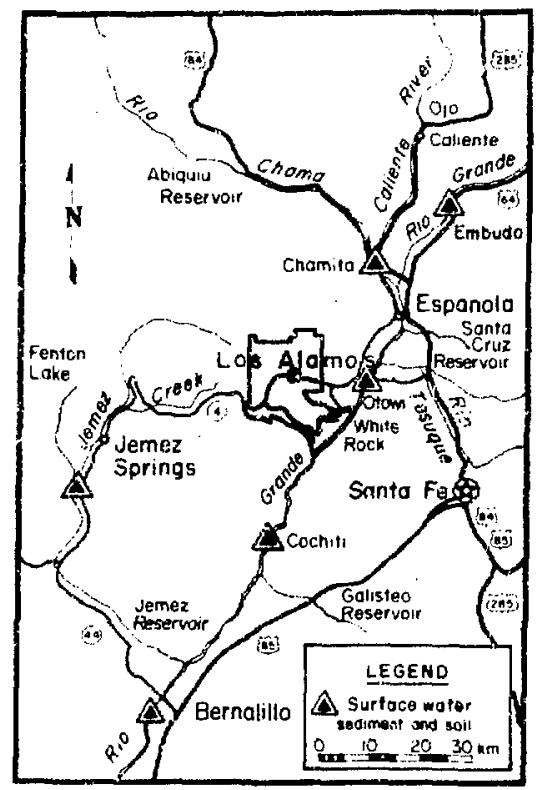

Fig. 11. Regional surface water, sediment, and soil sampling locations. 
The maximum observed concentrations of radioactivity is the regional, perimeter, ard on-site soi: and sediments are

\begin{tabular}{|c|c|c|c|}
\hline Analyses & Units & $\begin{array}{l}\text { Regional } \\
\text { and } \\
\text { Ferimeter }\end{array}$ & On-Site \\
\hline $3_{\mathrm{H}}$ & $10^{-6} \mu \mathrm{Ci} / \mathrm{m} \Omega$ & 123 & 8.3 \\
\hline${ }^{238} \mathrm{Pu}$ & $\mathrm{fCi} / \mathrm{g}$ & 3.5 & 5000 \\
\hline $239 \mathrm{Pu}$ & $\mathrm{fCi} / \mathrm{g}$ & 44 & 1200 \\
\hline Gross a & $1 \times 1 / 9$ & 8 & 5.9 \\
\hline Gross B & $\mathrm{pCi} / \mathrm{g}$ & 9.8 & 10 \\
\hline Total U & $\mu g / g$ & 3.8 & 2.8 \\
\hline
\end{tabular}

The regional and perimeter analyses results for 1975 are consistent with those for 1974. The plutonium values are similar to fallout determinations in the region with $238_{\mathrm{Pu}}$ ranging from $<1$ to $4 \mathrm{fCi} / \mathrm{g}$ and ${ }^{239} \mathrm{Pu}$ ranging from $<1$ to $23 \mathrm{fCi} / \mathrm{g} \cdot{ }^{5}$ one ${ }^{3} \mathrm{H}$ value of $123 \mathrm{pCi} / \mathrm{m} \ell$ occurred at a perimeter soil station which is near the tritium processing laboratory at TA-33. The range of remaining regional and perimeter analyses was from 1.9 to $4.8 \mathrm{pCi} / \mathrm{m} \ell$ of ${ }^{3} \mathrm{H}$. Plutonium values Erom on-site locations are nigher because the results include analyses from sediments in the canyons that have received, or are now receiving, industrial effluents (Pueblo, DP-Los Alamos, and Mortandad Canyons). Remaining on-site soils and sediment anaiytical results are comparable to the regional and perimeter values.

IX. RADIOACTIVIT" IN FOODSTUFFS

A sampling program was initiated during CY 75 in order to evaluate possible dose commitment resulting from the consumption of locally produced foodstuffs. As an initial objective, radionuclide detectability was established for certain foodstuff samples collected during the fall harvest. Sampling locations included Los Alamos County and the Rio Grande Depression (both above and below the corfluences of Laboratory-site originating stream channels; see Fig. 2). Levels of tritium oxide (HTO), ${ }^{238} \mathrm{Pu}$ and ${ }^{239} \mathrm{pu}$, and uranium were determined for selected samples of fruits, vegetables, and cows' milk.
Plutonium analyais of foodstuff samples generally yielaed values below the detection limit, i.e., where the 20 analytical error is greater than the principal value. Of the $23^{238} \mathrm{Pu}$ and $23^{239} \mathrm{Pu}$ analyses, the six values above the detection limit are

\begin{tabular}{|c|c|c|c|c|}
\hline Location & $\begin{array}{l}\text { Water } \\
\text { Source }\end{array}$ & Sample & $\frac{\mathrm{fCi} / \mathrm{g}}{238 \mathrm{Cu}}$ & $\frac{\mathrm{y} w \mathrm{t})}{239 \mathrm{Pu}}$ \\
\hline $\begin{array}{l}\text { TA }=1^{\mathrm{a}} \\
(\text { N90EBO) }\end{array}$ & $\begin{array}{l}\text { soil } \\
\text { thoisture }\end{array}$ & praches & $=$ & $\begin{array}{l}3.2 \\
( \pm 1.0)\end{array}$ \\
\hline $\begin{array}{l}T A-1^{a} \\
(N 90 E 80)\end{array}$ & $\begin{array}{l}\text { soil } \\
\text { moisture }\end{array}$ & apgles & $\begin{array}{l}0.25 \\
( \pm 0.20)\end{array}$ & $\begin{array}{l}0.37 \\
( \pm 0.20)\end{array}$ \\
\hline $\begin{array}{l}\text { villa st. } \\
\text { (N160840) }\end{array}$ & $\begin{array}{l}\text { L. A. } \\
\text { county }\end{array}$ & lettuce & -- & $\begin{array}{l}1.8 \\
( \pm 1.0)\end{array}$ \\
\hline Cochiti & $\begin{array}{l}\text { Rla } \\
\text { Grande }\end{array}$ & $\cos n$ & -- & $\begin{array}{l}0.10 \\
( \pm C .10)\end{array}$ \\
\hline Egpanola & $\begin{array}{l}\text { Rio } \\
\text { Chanab }\end{array}$ & carrots & -- & $\begin{array}{l}0.68 \\
( \pm 0.39)\end{array}$ \\
\hline
\end{tabular}

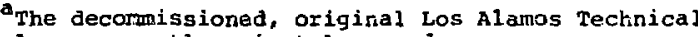
Area currently privately owned.

$b_{A}$ tributary of the $R$ :. G Grande.

Pritium in foodstuffs was determined by distillation of the samples and subsequent liquid scirtillation analysis of the iis-tillate. The data presented below summarize the tritium content in water from various samples according to different water supplies. The values were within a range comparable to meteoric concentrations.

\begin{tabular}{|c|c|c|c|c|}
\hline \multirow[b]{2}{*}{ Location } & \multirow[b]{2}{*}{ Water source } & \multirow{2}{*}{$\begin{array}{l}\text { No. of } \\
\text { Samples }\end{array}$} & \multicolumn{2}{|c|}{$\begin{array}{l}\text { Tritium } \\
\text { Concentration } \\
\text { (pci/me) } \\
\end{array}$} \\
\hline & & & Average & Ratige \\
\hline Espanola & Rio Chama & 4 & $5( \pm 6)$ & $1.8 \cdot 9.0$ \\
\hline Rarchitos & Rio Grande ${ }^{a}$ & 4 & $5( \pm 10)$ & $1.5-12.8$ \\
\hline Cochiti & Rio Grande b & 6 & $5( \pm 2)$ & $3.7-6.2$ \\
\hline White Rock & L.A. County & 5 & $3( \pm 1)$ & $2.8-4.0$ \\
\hline Ios Alamos & I.A. County & 3 & $9( \pm 3)$ & $5.4-7.5$ \\
\hline Los Alamos & soil moisture & 2 & $15( \pm 14)$ & $10.2-2.0$ \\
\hline
\end{tabular}

apstrear from Laboratory stream confluence.

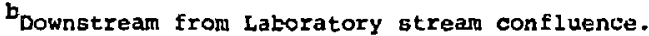

Uranium concentrations in foodstuff

samples are presented below according to water supply.

$\begin{array}{ll}\text { Location } & \text { Water Source } \\ \text { Espanola } & \text { Rio Chama } \\ \text { Ranchitos } & \text { Rio Grande } \\ \text { Cochiti } & \text { Rio Grande } \\ \text { White Rock } & \text { L.A. County } \\ \text { Los Alamos } \text { L.A. County } \\ \text { Los Alamos soil moisture }\end{array}$

\begin{tabular}{|c|c|c|}
\hline \multirow{2}{*}{$\begin{array}{l}\text { No. of } \\
\text { Samples }\end{array}$} & \multicolumn{2}{|c|}{$\begin{array}{c}\text { Uraniun } \\
\text { (ng/g dry wt) }\end{array}$} \\
\hline & Average & Range \\
\hline 4 & $19( \pm 24)$ & $6-36$ \\
\hline 4 & $10( \pm 8)$ & $7-16$ \\
\hline 6 & $B( \pm B)$ & $2-29$ \\
\hline 5 & $14( \pm 24)$ & $2-12$ \\
\hline 2 & $76( \pm 100)$ & $6-146$ \\
\hline 2 & $5( \pm 8)$ & $2-8$ \\
\hline
\end{tabular}

apstream from Laboratory strean confluence.

bownstrean from Laboratory strear confluence. 
$x$. RADIATION DOSE ASSESSMENT

A. Methods and Assumptions

The radiation dose assessments presented in this section are based on the environmental monitoring data of this report. Calculations are made for the radionucliaes detected by the IASL monitoring network and For critical pathways associated with these effluents. The calculations represent estimates of doses incurred during the 1-yr period covered by the monitoring data. The calculational models are those recommended by the ICRP. $7,12,13$ No Laboratory-related concentrations of radionuclides were detected beyond a 20-km radius of the Laboratory; coinsequently, it was not considereà necessary to do population dose assessments beyond Los Alamos County. The 1975 Los Alamos County population estimates $(12000$ and 5700 people in Los Alamos and White Rock, respectively) were obtained from the Los Alamos County Planning Department. For background purposes, the population of the $80-\mathrm{km}$ radius about the Laboratory (94 000) was obtained from the LASL-developed Pathfinder Program ${ }^{14}$ with updating from the "Statistical Abstract of the United States - 1975."

B. External Penetrating Radiation

variations in terrestrial radiation and cosmic radiation complicate any analysis of external radiation exposure as measured by the TLD network (Table VII). With the exception of the station at State Highway 4 (16), the highest exposure was at Cumbres Schoo1. High-pressure ionization chamber measurements taken at the cumbres school station and on the lawn at Cumbres School showed that the dose rate at the TLD station was 228 higher than on the lawn. This indicates that the natural radioactivity in the materials making up the brick enclosure for the cumbres station contribute a significant percentage of the dose measured at Cumbres school. This station has now been moved to a different location.

As was discussed earlier, the measured dose at State Highway 4 is believed to result from radionuclide contamination from radioactive Itguid waste discharges into canyons upstream from this station. This dose does not represent a dose to che people of Los Alamos County because there is no regidence of usage of this area by the populace. With the exception of the State Highway 4 station, all perimeter and off-site stations have dose rates compatible with the expected values (between 126 and $175 \mathrm{mrem} / \mathrm{yr}$ ) estimated for New Mexico by the EPA.10,11 The mean dose rate of $130 \mathrm{mrem} / \mathrm{yr}$ at background stations on the Pajarito Platezu is similar to a ThD measured dose rate of 143 mrem/yr at Colorado springs, colorado. 15 Because there was no indication of off-site incremental external penetrating radiation resultin, 'rom Laboratory operations, individual and population doses for such an exposure were not calculated.

\section{c. Radioactivity in Air}

The whole-body dose resultant .rom continuous inhalation of tritiated water vapor can be calculated using the equation $n=$ $1.2 \times 10^{6} \mathrm{C}$ (where $\mathrm{D}=$ ciose in rems ind $\mathrm{C}=$ concentration in $\mu(i / m \ell)$. Derivation of this equation is given in previous reports. 5-7,12,13 However, inhalation is not the only means of entry of tritiated water vapor into the body. At rest or during light activity, the rate of vapor abscrption by the lungs is approximately equal to the rate by way of exposed skin of the whole body. 13 clothing provides only a short-term, temporary barrier to water vapor so the entire skin surface of the body should be cunsidered as exposed to the tritiated water vapor. Thus, the constant in the above equation should be doubled because of the doubling of the intake of tritiated water vapor. The equation used for dose calculations for this report is then $D=2.4 \times 10^{6} \mathrm{C}$. The average airborne tritium concentration at background stations 9, 10, and 11 (see Table $\mathrm{IX}$ ) was $14 \times 10^{-12} \mu \mathrm{cl} / \mathrm{ml}$ which results in a whole-body dose of $0.034 \mathrm{mrem} /$ YI. The highest average airborne tritium concentration at an occupied location in 1975 was $88^{\circ} \times 10^{-1.2} \mu \mathrm{Ci} / \mathrm{ml}$ at the Los Alamos 
Airport. This average concentration results in a whole-body dose of $0.18 \mathrm{mrem} / \mathrm{y}$ above background, which is 0.0368 of the annual dose limit of $500 \mathrm{mrem} / \mathrm{yr}$ for an individual member of the public and 0.118 of the dose limit of $170 \mathrm{mrem} / \mathrm{yr}$ for a suitable sample of the population (ERDAM 0524).

The highest dose at a site boundary is approximated by the average concentration of $156 \times 10^{-12} \mu \mathrm{Ci} / \mathrm{ml}$ at $\mathrm{TA}-33$. This concentxation represents a whole-body dose above background of 0.34 mrem, which is 0.0688 of the individual dose linit.

An estimate of the dose contribution to the Los Alamos community from airborne tritlated water vapor was obtained by averaging the annual concentration measured at stations 1-7 for the townsite and stations 8 and 20 for White Rock. The concentrations of $2.2 \times 10^{-12}$ and $25 \times 10^{-12} \mathrm{yCi} / \mathrm{ml}$ for the townsite and white Rock, respectively. and allowing for a population of 200 near the Los Alamos Airport being exposed to 88 $x 10^{-12} \mu \mathrm{Cl} / \mathrm{m} \ell$, give a resultant calculated population dose above background of 0.42 mon-rem to the estimated 17700 residents of Los Alamos County. This populrtion dose represents the whole-body dose irom Laboratory effluents to the populace within an 80-km radius of the Laboratory. By coingarison, the 17700 residents of I.os Alamos County would receive 2550 man-rem, and the population of 94000 residents within the 80 -km radius would receive 13500 man-rem, from natural radiation scurces. (This calculation assumes that the individual dose from cosmic, terrestrial, and internal radioactivity was $144 \mathrm{mrem} / \mathrm{yr}^{10}$ ).

For ${ }^{239} \mathrm{Pu}$ in air, two stations are of possible interest--Fuller Lorige and TA-6 (Table XI). Both have mean concentrations of ${ }^{239} \mathrm{Pu}$ in air significantly above means from other stations. Each mean is strongly influenced by its maximum value. These maxima appear as a strong spike in plots of concentration vs time. No other station in the network recorded a spike for these times. It is unlikely that a release could have occurred within the Laboratory confines that would only be detected at Fuller lodge or at TA-6. However, it is assumed for this discussion that each station experienced a localized phenomenon.

The incremental lung doses above background for the mean concentrations of $53 \mathrm{x}$ $10^{-18}$ and $29 \times 10^{-18} \mu \mathrm{Ci} / \mathrm{ml}$ for $\mathrm{TA}-6$ and Fuller Lodge, respectively, were calculated from the formula $\mathrm{D}=1.3 \times 10^{12} \mathrm{C}$ (where $\mathrm{D}=$ lung dose in rem and $C=$ concentration in $\mu \mathrm{Ci}, \mathrm{m}()$ which has been developed previously. $5-7,12,13$ with a oackground subtraction of $17 \times 10^{-18} \mu \mathrm{Ci} / \mathrm{ml}$ (average of the concentrations at Espanola, Pojoaque, and Santa Fe) the incremental $239 \mathrm{Pu}$ lung doses above background at $\mathrm{TA}-6$ and Fuller Lodge are 0.047 and $0.016 \mathrm{mrem} / \mathrm{Yr}$, respectively. These coses are 0.0038 and 0.0018 of the indiviaual dose limit of $1500 \mathrm{mrem} / \mathrm{yr}$, respectively.

The rance of values (means and maximum) for ${ }^{238} \mathrm{Pu}$ concentrations in air, as shown in Iable XI, all fall within the range of $0.2-8.8 \times 10^{-18} \mu \mathrm{Ci} / \mathrm{ml}$ measured as fallout at 11 stations throughout the United states by the U. S. Environmental Protection Agency Radiation Alert Network.16-19 Hence, no dose assessment was calculated for atmospheric $238 \mathrm{pu}$.

Measurement of atmospheric ${ }^{24} 1_{\text {Am }}$ involves difficult chemical procedures and is attempted by only a few laboratories throughout the country. In the 241 Ar measurements reported in Table XI, the values for Los Alamos Aixport $\left(22 \times 10^{-1 B} \mu \mathrm{Ci} / \pi \ell\right.$; and TA-6 (11 $\times 10^{-18} \mu \mathrm{Ci} / \mathrm{m}$, ) are above the others. It is not clear whether these data represent real concentrations from worldwide falluut, labcratory procedural difficulties, or IASL effluent releases. The calculated dose to the lung from these conrentrations, allowing for no background subtraction, would be 0.031 and $0.015 \mathrm{mrem}$ for the airport and TA-6 stations, respectively; these values are 0.0028 and $0.001 \%$ of the individual lung dose limit, respectively. These doses were calculated from 
the formula $\mathrm{a}^{5-7}, 12,13 \mathrm{D}=1.4 \times 10^{12} \mathrm{c}$ (where $D=$ dose in rems and $C=$ concentration in $\mu(i / m l)$.

The annual average concentrations of airborne uranium range from 22 to $97 \mathrm{Eg} / \mathrm{m}^{3}$ (Table XII). The atmospheric uranium concentrations are variable, and statistically significant spatial variations in the data were not indicated. The maximum uranium ccacentration of $97 \mathrm{pg} / \mathrm{m}^{3}$, observed at the perimeter station at Acorn Street, was 0.001 and $0.00005 \%$ of the respective uncontrolledand controlled-area cGs. Since the observed concentrations are in an expected range resulting from natural sources (i.e., from resuspended continental crustal material), a calculation of Laboratory influenced dose was not indicated for this radionuclide. D. Other Nucilides and Pathways

Tritium, uranium, and transuranic nuclides are the only significant radioactive materials released from LASL facilities. Although some short-lived radionuclides are routinely measured in Laboratory effluents, they are not detectable in environmental media. The potential doses from these other nuclides are orders of magnitude smaller than the doses from the nuclides evaluated in the preceding sections and consequently are not considered in the overall dose assessment.

Liguid effluents, per se, do not flow beyond the LASL boundary but are absorbed in the alluvium of the receiving canyons; excess moisture is lost primarily by evapotranspiration. These effluents are monitored at the points of discharge and in the alluvium of the canyons below the outfalls. small quantities of radioactive contaminants have been measured in caryon sediments beyond the LASL boundary, probably transported there during periods of heavy runoff. However, no pathways from the sediments to humans have been identified.

No radioactivity in excess of normal background concentrations was detected in drinking water, perennial surface water, or ground water at any off-site location.
There are no known significant aquatic pathways or food chains to humans in the local area. Consequently, no potential dose contributions beyond those already discussed could be identified or evaluated.

XI. CHEHICAL QUALITY OF SURFACE AND GROUND WATERS

Monitoring of selected chemical quality parameters of surface and ground waters provides an alditional means for detecting the potential dispersion of effluents from LASL operations. Water samples are collected in 1- $\ell$ polyethylene bottles and returned to the laboratory for filtration through whatman $\# 2$ filters. Standard methods are used to analyze samples for gross chemical. characteristics and a selected list of Ions. Samples are collected twice a year for chemical quality analyses.

A. On-site surface and Ground Waters

Chemical analyses were made on samples from three on-site ground water and three on-site surface water locations that are not in saboratory effluent release areas (Fig. 10, rable XVI). There was no indication of any significant change from previous reporting periods. ${ }^{5,6}$ These waters all met drinking water standards (Table $v$ ) for the constituents measured; however, none of them is used for municipal or domestic supply. The maximum concentrations of $\mathrm{Cl}^{-}, \mathrm{F}^{-}, \mathrm{NO}_{3}^{-}$, and total dissolved solids (TDS), constituents that are indicators of Laboratory releases, for these six stations are

\begin{tabular}{cc} 
Constituent & $\begin{array}{c}\text { Maximum } \\
\text { Concentration } \\
(\mathrm{mg} / \ell)\end{array}$ \\
\cline { 2 - 2 } $\mathrm{Cl}^{-}$ & 134.0 \\
$\mathrm{~F}^{-}$ & 1.1 \\
$\mathrm{NO}_{3}^{-}$ & 7.5 \\
$\mathrm{TDS}^{-}$ & 450.0
\end{tabular}

Chemical quality was determined for samples of surface and ground waters in canyons which are current or former recipients of industrial effluents (Fig. 10 . Table XVI). Acid-Pueblo Canyon received industrial wastes from 1943 to 1964 and currently receives treated municipal sewage 
effluent, which is a large portion of the total flow. Sandia Canyon receives cooling tower blowdown from the TA-3 power plant and some treated sewage effluent. Except for snowmelt or storm runoff, these effluents constitute the total flow in Sandia Canyon. DP-Los Alamos Canyon receives effluents from industrial waste and sanitary sewage treatment plants and cooling tower blowdown from TA-2l and TA-2. Mortandad canyon receives the effluent from the Central Waste Treatment Plant at TA-50. This effluent is a major part of the flow except during storm runoff or spring snowmelt. The maximum observed concentrations of $\mathrm{Cl}^{-}, \mathrm{F}^{-}, \mathrm{NO}_{3}^{-}$, and TDS for these canyons are

\begin{tabular}{|c|c|c|c|}
\hline $\begin{array}{l}\text { Acid- } \\
\text { Pueblo }\end{array}$ & Sandia & $\begin{array}{l}\text { DP-Los } \\
\text { Alamos }\end{array}$ & $\begin{array}{l}\text { Mor- } \\
\text { tandad }\end{array}$ \\
\hline 65 & 470 & 98 & 28 \\
\hline 1.0 & 1.4 & 3.6 & 1.7 \\
\hline 59 & 33 & 90 & 480 \\
\hline 410 & 1500 & 840 & 1100 \\
\hline
\end{tabular}

The chemical quality of waters in each of these areas is clearly influenced by the input of effluents. None of these waters is a source of either municipal or domestic water supply, but the surface waters in these canyon areas are used by wildlife. In some places these waters do not meet drinking water standards for chemical criteria, particularly for TDS, $\mathrm{F}^{-}$, and $\mathrm{NO}_{3}^{-}$, but they do meet proposed $\mathrm{EFÄ}^{20}$ criteria for these substances in water used for livestock.

\section{B. Off-Site and Supply Waters}

Perimeter surface water and ground water is sampled at six locations (Fig. 10 , Table XVII). Locations on regional rivers and reservoirs within $75 \mathrm{~km}$ of LASL (Fig. 11. Table XVIII) are sampled to provide data on the chemical quality of water in the area. All of these waters meet drinking water standards for the constituents measured, with the occasional exception of TDS. No significant changes from previous reporting periods have been noted. 5,6 The maximum observed concentrations of $\mathrm{Cl}^{-}, \mathrm{F}^{-}$,
$\mathrm{NO}_{3}{ }^{-}$, and TDS for these pfrimeter and regional samples are

\begin{tabular}{|c|c|c|}
\hline \multirow[b]{2}{*}{ Constituent } & \multicolumn{2}{|c|}{ Maximum Concentrations (mg/l) } \\
\hline & Regional & Perimeter \\
\hline $\mathrm{Cl}^{-}$ & 110 & 43 \\
\hline$F^{-}$ & 1.0 & 2.5 \\
\hline $\mathrm{NO}_{3}^{-}$ & 1.3 & 26 \\
\hline TDS & 470 & 360 \\
\hline
\end{tabular}

The Los Alamos water supply system, which serves the Laboratory and the community, is sampled at each of the 16 supply wells and a supply gallery, and at five points in the distribution system (Fig. 10. Table $X(X)$. The chemical quality varies slightly from periods of light production (winter) to pexiods of heavy pumpage (summer). Maximum concentrations for all substances measured are well below the EPA Interim Primary Drinking water Standards (Table $v)$ with the exception of arsenic. One supply well in Los Alamos Canyor, routinely produces water samples with concentrations of naturally present arsenic up to about three times the EPA standard. In the past, dilution by water from other wells has reduced the concentration of arsenic in the distribution system to levels meeting standards. During 1975, increasingly higher concentrations occurred in water samples from the well, occasionally resulting in levels of arsenic in parts of the distribution system that exceeded the standard. The well was taken out of service in August 1975. Studies are under way to determine the source of the arsenic in the well and means of controlling well pumpage so that levels in the distribution system meet standards continuously.

c. Fenton Hill Site Surface and Ground Waters

The chemical quality of surface and ground waters in the vicinity of the Fenton Hill site of the LASL Dry Hot Rock Geotherral Energy Experiment $(\approx 30 \mathrm{~km}$ of Los Alamos, see Fig. 2) has been measured to fulfill monitoring requirements and provide basi: information for environmental studies. The results of a preliminary study and data 
for 1974 have been reported elsewhere. 21,22 These studies have shown that quality of surface water in the drainage area of the Jemez River and the Rio Guadalupe is complex. Sources of the base flow in the various streams in the drainage area of the Jemez River differ in chemical quality. Predominant ions in streams that drain the Valles Caldera were sodium and chloride in Redondo Creek, calcium and sulfate in sulphur creek, and calcium and bicarbonate in San Antonio creek. The mixture of water from these three streams in the Jemez River below the junction with the East Fork of the Jemez results in water which contains a significant quantity of sodium and bicarbonate. Inflow of mineral and thermal springs into the river below the East Fork is highly mineralized and contributes sodium and chloride. Inflow from the springs is the main contribution to a decrease in water quality in the remainder of the Jemez River.

Predominant ions in the water from the Rio Cebolla and Rio Guadalupe drainage area are calciun and bicarbonate. Springs discharging from the Cenozoic volcanic substrate contain significant quantities of sodium and bicarbonate.

Table XX summarizes the results of chemical quality analyses ferformed during 1975. The samples were collected from 9 surface water and 14 grcund water sources (Fig. 12) three times during the year. Ponded drilling fluids were sampled irregularly. The results are presented as averages for groups of sampling locations with retated characteristics. No significant changes from previous data were observed. 21 . 22

XII. ECOLOGICAZ STUDIES

A. Long-Term Ecological Effects of Ex-

posure to Uranium

Several thousand kilograms of natural uranium (U) and depleted uranium (DU) have been dispersed to the environment at several LASL explosives testing sites as a result of development and testing exercises from 1949 (J the present. 23 Two explosives testing areas were selected for study on the basis of their use history: E-F Testing Site, located within TA-15, and Lower Slobbovia Testing site, located within TA-30. Objectives of initial studies of U-DU released to the LASL tegting site environs were to

1. describe the concentration and distribution of uranium in the environs by analyzing appropriate samples of soil and biota,

2. describe resident plant communities and small mammal populations which have been exposed to varying amounts and physical forms of uranium.

3. analyze the composition of plant and soil invertebrate communities associated with various gradients of uranium present in the environs to cetermine possible responses to uranium chemical toxicity.

$E-F$ Testing site showed averages of $2400 \mathrm{ppm}$ of U-DU in the upper $5 \mathrm{~cm}$ of $\mathrm{soil}$ and $1600 \mathrm{ppm}$ in the 5- to 10-cm depth.

Lower Slobbovia Testing site had two subplots in which soil U-DU concentrations were about 2.5 and 0.68 of the E-F site values. Differences in the U-DU concentrations in soil, with depth and distance from detonation points, were ascribed to the different explosives test designs peculiac to each area.

Dry-weight concentrations of U-DU in unwashed vegetation samples at the E-F site were about 320 ppm during November 1974 and about $125 \mathrm{ppm}$ during June 1975. These apparent variations in vegetation $U-D U$ concentrations were probably due to: (1) variable external deposition over considerable time, (2) the different species of plants available at sampling times, and (3) the greater amounts of fresh growth included in the June 1975 samples that effectively reduced the concentrations by dilution of the blomass. Ratios of plant/soil U-DU concentrations varied from 0.08 during November to 0.05 during June. This is within the range reported from other studies of plants in high uranium areas. 24 


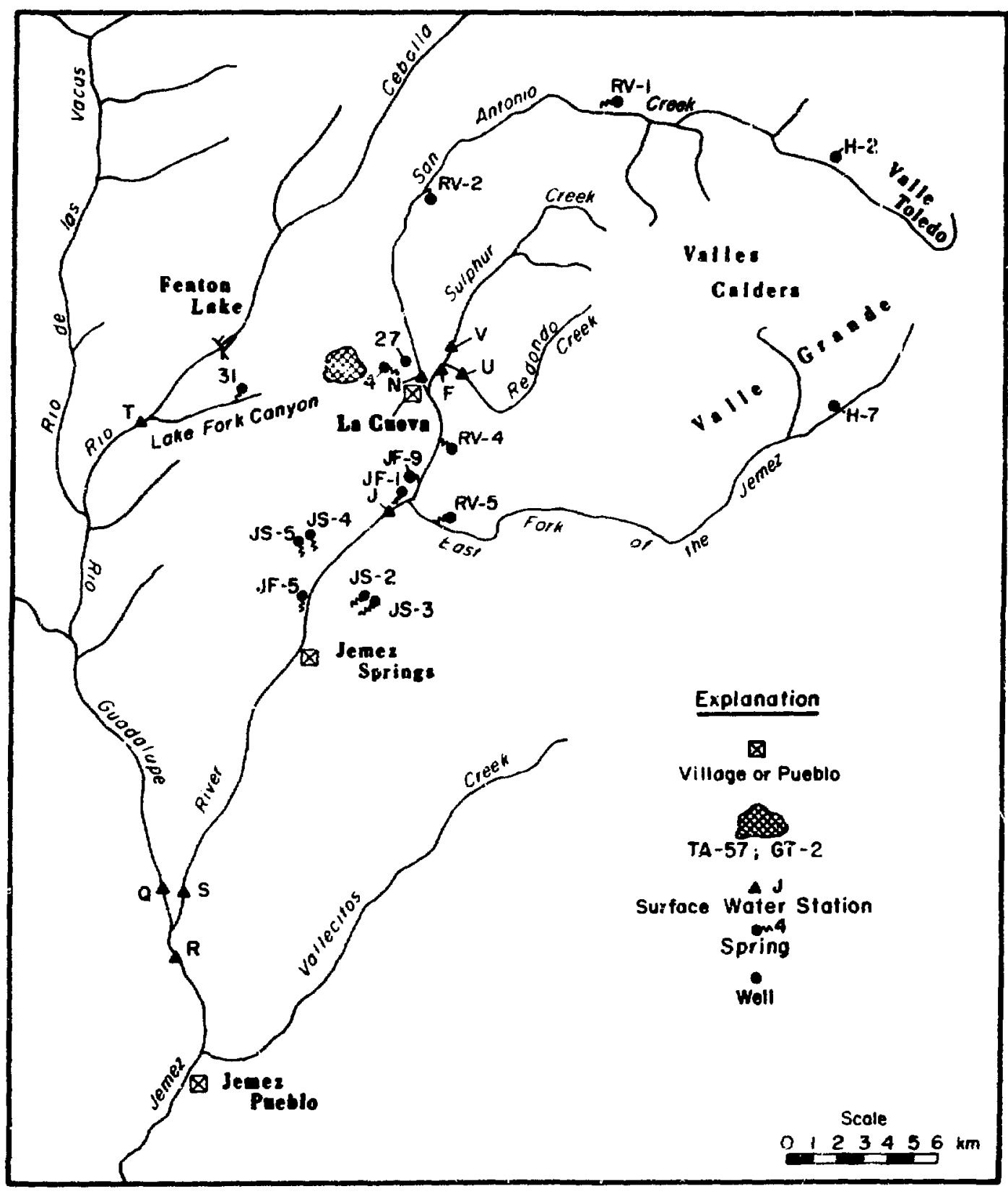

Fig. 12. Fenton Hill Sampling station map. 
Small mammals trapped in the study areas during November contained mean dryweight concentration values $i n=17$ ) of 210 ppm U-DU in gastrointestinal tract contents, $24 \mathrm{ppm}$ in the pelt, and $4 \mathrm{ppm}$ in the remaining carcass. During June, mean $(n=9)$ dry-weight concentrations were 110, 50, and 2 ppm in similar samples, and $6 \mathrm{ppm}$ in lungs. Lung samples from rodent species that actively forage on the ground surface were about eight times greater in U-DU concentration than similar samples from subterranean pocket gophers. These data emphasize the importance of resuspension of respirable particles in the upper few millimeters of soil as a contamination mechanism in several components of the ecosystem.

Vegetation community composition and initial results of the soil invertebrate studies did not reveal conclusive differences between areas of high and low soil concentrations of $U-D U$ in the study sites and their control counterparts. Soil and surface litter macrofauna $(0.2-2.0 \mathrm{~mm}$ in length) populations appeared to be reduced at the high U-DU study area compared to the adjacent control area; however, more intensive sampling is required to determine the significance of the observation. The anomalous character of the $E-E$ firing point, compared to its adjacent control area, complicated the faunistic studies because of strong environmental influences upon soil moisture, absorbed solar radiation regimes, and aspect responses; this may require adjustment of the study areas to provide more comparable sampling sites.

B. Storm Runoff Transport of Plutonium in Mortandad Canyon

Rainstorm runoff was identified as a potential mechanism in radioactivity transport at Los Alamos nearly 30 years ago. 25 Work has recently begun to characterize and quantify runoff transport of trace plutonium and ${ }^{137} \mathrm{Cs} .26,27$ The results of the work concerning ${ }^{137} \mathrm{Cs}$ in Mortandad Canyon ${ }^{27}$ were summarized in the environmental surveillance report for $1974 .^{5}$ The corresponding plutonium concentration data are presented here along with the comparative behavior of the two elements.

The runoff event investigated in this study resulted from a $2.9-\mathrm{cm}$ rainstorm on the upper Mortandad Canyon watershed. Samples were taken through a $4.25-\mathrm{h}$ period at one location $1200 \mathrm{~m}$ below the liquid waste effluent outfall to associate the respective radionuclides with the suspended sediment and liquid fractions and to measure the total activities transported by the event. The concentrations of ${ }^{137} \mathrm{Cs},{ }^{238} \mathrm{Pu}$, and $239-240 \mathrm{Pu}$ in runoff samples exhibited very similar patterns with time. The filtered water contained low concentrations of all the radionuclides; levels ranged from about $30-80 \mathrm{pCi} / \ell^{137} \mathrm{Cs}, 2-5 \mathrm{pCi} / \ell{ }^{238} \mathrm{Pu}$,

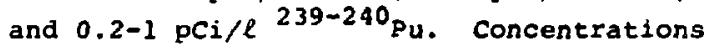
of the radionuclides in water were variable and did not exhibit a consists:1t pattern with time. However, concentrations of aIl three radionuclides in suspended sediment were relatively high, ranging from 100-600 $\mathrm{pCi} / \mathrm{g}{ }^{137} \mathrm{Cs}, 10-100 \mathrm{pCi} / \mathrm{g}^{239} \mathrm{Pu}$, and $1-10$ $\mathrm{pCi} / \mathrm{g}$ 239-240 $\mathrm{Pu}$, and generally increased throughout the event. The total amount of radioactivity associated with suspended sediments in each water sample $(\mathrm{pCl} / \mathrm{l})$ steadily decreased through the runoff event though the concentrations (pci/g) generally increased.

Significantly higher $(\mathrm{P} \leq 0.05)$ concentrations of the radionuclides were measured in particulate samples collected near the surface of the flow compared to those collected from near the bottom of the stream channel, partly due to a greater proportion of fine particle sizes in the surface samples. Previous studies in this canyon have shown that particles less than 53-um diam comprised only 28 of bed sediments by weight, but contained about 158 of the radioactivity. About 18 of the radionuclide inventory in each sample was present in the water fraction, whereas 998 was associated with the suspended pariciculates. More total 
radioactivity was associated with suspended sediments in bottom samples than with corresponding surface samples, even though the latter exhibited significantly higher radionuclide concentrations.

There was a significant relationship $(P \leq 0.05)$ between ${ }^{137} \mathrm{Cs}$ and the corresponding plutonium isotopes in the suspended sediment samples. This relationship was observed previously in Mortandad Canyon sediments and indicates that the two elements are distributed similarly along the stream channel and in the various size fractions.

The changes in radionuclide and suspended sediment concentrations were both relatively unaffected by flow rates in the range $0.07-0.25 \mathrm{~m}^{3} / \mathrm{s}$, possibly indicating that all available fine materials were in suspension at these flow rates. However, Fadionuclide and suspenaed sediment concentrations were directiy correlated with increasing flow in the range of $0.25-0.3 \mathrm{~m}^{3} / \mathrm{s}$. It seems likely that the water flowing at rates in excess of about $0.25 \mathrm{~m}^{3} / \mathrm{s}$ suspended the coarser particles (>105 $\mathrm{\mu m}$ ) which contained over 958 of the bulk and 808 of the radionuclide inventory.

Suspended sediment concentrations were used in a power function relationship to predict total concentrations of the specific radionuclides in runoff water samples. The equations resulting from the least squares fit of the data were

$$
\begin{aligned}
& Y=110 x^{0.40}, r^{2}=0.82, n=11 ; \\
& Z=14 x^{0.47}, r^{2}=0.87, n=11 ; \text { and } \\
& C=580 x^{0.62,} r^{2}=0.94, n=11 ;
\end{aligned}
$$

where $Y, Z$, and $C$ are the average total $238 \mathrm{Pu}, 239-240 \mathrm{Pu}$, and ${ }^{137} \mathrm{Cs}$ concentrations, respectively, in unfiltered runoff water $(p C i / \ell)$, and $x$ is the average suspended sediment concentration $(g / \ell)$. The coefficients of determination $\left(r^{2}\right)$ were all highly significant $(P \leq 0.01)$.

The total amount of radioactivity transported by the event was calculated from average total radinnuclide concentrations and accumulative runoff throughout the event. The estimated transport was $0.5 \mathrm{mCi}$
${ }^{137} \mathrm{Cs}, 1.1 \mathrm{mCi}{ }^{238} \mathrm{Pu}$, and $0.2 \mathrm{mCi}{ }^{239-240} \mathrm{Pu}$. In the case of plutonium, this activity represents $1-28$ of the total inventory of the canyon as of September 1975.

The most efficient transport of radionuclides occurred during the beginning of the storm runoff event when sediment concentrations were high as a result of high velocities and flow rates. Nearly 808 of the sediments and 708 of the radioactivity were transported during the first $120 \mathrm{~min}$ of the 270-min observation period.

In the 12 years that Mortandad Canyon has been receiving treated effluents, over 508 of the radioactivity has been transported into the dry portion of the canyon by snowmelt and storm runoff. The relative distribution of plutonium within the canyon demonstrates that transport occurs beyond the extent of surface water and that runoff from summer rainstorms can transport radionuclides in landscapes exhibiting these hydrologic features. There appears to be a highly significant relationship between suspended sediment concentrations and total amounts of radioactivity in water. The flow rates achieved during runoff events play an important part in determining the total amount of sediment and thus radioactivity transported downstream.

Although fine materials i<53 $\mu \mathrm{m})$ exhibjted higher radionuclide concentrations, the bulk of the radioactivity was associated with the more abundant coarse materials which serve as the most important sediment component involved in radionuclide transport. The water fraction was relatively unimportant although the water flow served as the transport vector.

Additional studies are to be conducted to determine the radionuclide transport characteristics of runoff events which vary in size from the one examined in this study. Particle size determinations would be valuable in relating flow rates (or velocity) to types of suspended material in the runoff. ractors to minimize runoff include adequate planning during site construction activities, 
revegetation of disturbed areas, and engineering practices which minimize channeling. Storm runoff serves as a transport vector for sediment-deposited radioactivity much the same as wind in arid terrestrial environments.

C. Radionuc1ides in Rio Grande Sediments and Fish

A sampling program was initiated in 1973 to measure the concentrations of selected radionuclides in $\mathrm{fish}$ and sediments from the Rio Grande, and preliminary results are presented here. Sampling locations were chosen along the river at the outfalls of the major canyons draining the Laboratory area and at about 2-km intervals downstream to the Cochiti Reservoir.

Sediment cores were obtained along the river and reservoir edges to depths of about $20 \mathrm{~cm}$. The samples were thoroughly mixed prior to radiochemical analysis.

The fish samples consisted of three species, namely carp (Cyprinus carpio), western white sucker (Catostomus commersoni), and Rio Grande chub (Gila nigrescens). These species generally feed on detritus, algae, and invertebrates; however, specific food habits are unknown in the sampling area. The complete carcass and the gastrointestinal contents were processed for radiochemical analyses.

All the available data from the Rio Grande fish and sediment sampling program are summarized in Table XXI. The means and coefficients of variation were obtained from all the data, including calculated concentrations that were negative or zero.

Data are not rurrently available on the ${ }^{137} \mathrm{Cs}$ concentrations in sediments from the sampling area. Plutonium concentrations in 35 separate sediment samples were generally not significantiy above the analytical detection limit of $0.005 \mathrm{pCi} / \mathrm{g}$. Concentrations of ${ }^{137} \mathrm{Cs}$ in three species of fish from the sampling area generally were not significantly above the detection limits of about $0.4 \mathrm{pCi} / \mathrm{g}$ dry tissue.
Five of the 19 samples collected in September 1974 contained measurable concentrations or ${ }^{137} \mathrm{Cs}$. However, these concentrations, which ranged from 1.3 to $1.8 \mathrm{pCi} / \mathrm{g}$ dry weight, can be attributed to worldwide fallout sources of ${ }^{137} \mathrm{cs}$.

Most of the plutonium data for fish are not available, with the exception of the September 1974 collection. Plutonium-238 was not detectable in any of the fish samples analyzed to date. A mean concentration of $0.9 \mathrm{fCi} / \mathrm{g}$ of ${ }^{239} \mathrm{Pu}$ was measured in $\mathrm{fish}$ with individual concentrations ranging from 0 to $7 \mathrm{fCi} / \mathrm{g}^{239} \mathrm{Pu}$.

The extremely low concentrations and high variability of ${ }^{137} \mathrm{Cs}$ and plutonium in fish and sediments demonstrate tre need to consider the level of sampling effort required to detect significant changes in radionuclide concentrations. A coupling of the experimental design with analytical capabilities and witr potential health implications is mandatory to providing meaningful data.

\section{UNPLANNED RELEASES}

On August 27, 1975, the contents of a 20 000- $\ell$ storage tank in the Central Waste Treatment Plant at TA-50 (see Fig. 4) foamed over causing about 3000 \& of a contaminated liquid-sludge mixture to flow out of the building. The foaming was apparently caused by the inadvertent mixing of an acid solution from ion-exchange column regeneration with a carbonate-rich sludge from radioactive waste treatment. The liquid escaping the building flowed over a portion of the blacktop parking lot and access road adjacent to tine building and onto a partly vegetated soil area. A total area of about $500 \mathrm{~m}^{2}$ was contaminated. The entire area was within a security-fenced Laboratory site. The liquid contained a mixture of radio:sotopes and had activity concentratione of approximately $40 \therefore 10^{-0} \mathrm{uCi} / \mathrm{ml}$ gross-alpha, $15 \times 10^{-6} \mathrm{vCi} / \mathrm{m} \ell$ gross-beta, and $140 \times 10^{-6} \mathrm{\mu l} / \mathrm{m} \ell$ gross-gamma. These activities were attributable primarlly to 


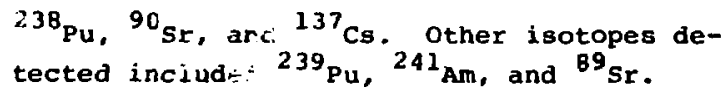
Soil was contam inated to maximum levels of about $2 \mathrm{nCi} / \mathrm{g}$ grossmalpha.

The contaminated blacktop and soil were dug up and loaded into plastic-lined trueks. about $80 \mathrm{~m}^{3}$ of contaminated material were hauled to the contaminated sclid waste disposal area at TA-54 on August 27, 1975.

Surveys with field instruments and gross-alpha analyses of soil samples identified some remaining contamination which was removed by hand excavation. Final stages of cleanup and documentation were delayed because of rain. The decontamination was completed on September 15, 1975. Soil samples taken at about $2-\mathrm{m}$ intervals over the excavated axea al! showed gross-alpha levels below the $20 \mathrm{pci} / \mathrm{g}$ detection limit of a zinc-sulfide analysis sytem used for the documentation. Continuous air monitoring measurements from the imnediate vicinity of the release and cleanup operations showed no measurable alpha activity greater than natural background levels.

\section{REFERENCES}

1. D. Balcomb, J. C. Hedstrom, S. W. Moore. and B. T. Rogers, "Solar Heating Handbook for Los Alamos," Los Alamos Scientific Laboratory report $2 A-5967-M S$ (May $1975)$.

2. D. H. Slade, ed., "Meteorology and Atomic Energy," U. S. Atomic Energy Commission report TID-24190 (July 196B).

3. F. Pasquil1, Atmospheric Diffusion. (D. Van Nostrand and Co., Ltd.. London 1962).

4. H. E. Cramer, G. M. De Santo, K. R. Dumbauld, P. Morgenstern, and R. N. Swanson, "Neteorological Prediction Techniques and Data System, Final Report," Contract No. DA-42-007-CML-552, U. S. Army, Dugway Proving Ground, Utah (March 1964).

5. K. E. Apt and V. J. Lee, compilers, "Environmental Surveillance at Los Alamos During 1974," Los Alamos Scientific Laboratory report LA-5977-PR (1975).
6. K. J. Schiager and K. E. Apt, compilers, "Environmental Surveillance at Los Alamos During 1973." Los Alanos Scientific Laboratory report LA-5586 (1974).

7. International Commission on Radiological Protection (ICRP), "Recommendations of the International Commission on Radiological Protection," ICRP Publ. 6, (Pergamon Press), New York (1964).

B. Environmental Protection Agency, "Environmental Radicastivity Laboratory Intercomparison Studifs Program, 1975," U. S. EPA report 680/4-75-002b (May 1975 ).

9. H. E. Johns and J.R. Cunningham, The Physics of Radiology. 3rd ed. (C. C. Thomas) Springfiald, IL, 1974.

10. D. T. Oakley, "National Radiation Exposure in the united states," U. S. EPA report ORP/SID 72-1 (1972).

11. A. W. Klement, Jr., et al., "Estimates of Ionizing Radiation Doses in the United States, $1960-2000, " U$. S. EPA report ORP/CSD 72-1 (1972).

12. International Commission on Radiological Protection (ICRP). "Report of Comnittee II on Permissible Dose for Internal Radiation, 1959," ICRP Publ. 2, (Pergamon Press), New York (1960).

13. International Commission on Radiological Protection (ICRP), "Evaluation of Radiation Doses to Body Tissues from Internal Contamination Due to Occupational Exposure," ICRP Publ. 10, 'Pergamon Press) New York (1968).

14. R. V. Fultyn, private communication, LASL/H-1, 2-5-75.

15. D. E. Jones, C. L. Lindeken, and R. E. McMillian, "National Radiation Background Dose Measurements with $\mathrm{CaF}_{2}: D y$ TLD," Lawrence Radiation Laboratory report UCRL-73432 (1971).

16. "Plutonium in Airborne Particulates. July-September 1972," Radiation Data and Reports, 14, 3, p. 208; office of Radiation Programs, Environmental Protection Agency, Washington, D.C., (March 1973).

17. "Plutonium in Airborne particulates, October-December 1972," Radiation Data and Reports, 14, 6, p. 383; Office of Radiation Programs, Environmental Protection Agency, Washington, D.C., (June 1973).

18. "Plutonium in Airborne Particulates. January-March 1973،" Radiation Data and Reports, 15, 5, p. 278-9; Office of Radiation Programs, Environmental Protection Agency, Washington, D.C., (May 1974). 
19. "Plutonium in Airborne Particulates, Apri1-June 1973," Radiation Data and Reports, 15, 6, p. 355; Office of Radiation Programs, Environmental Protection Agency, Washington, D.C., (June 1974).

20. "Proposed Criteria for Water Quality," Vol. I, Environnental Protection Agency (October 1973).

21. W. D. Purtymun, F. G. West, and W. J. Adams, "Preliminary Study of the Quality of Water in the Drainage Area of the Jemez River and Rio Guadalupe," Los Alamos Scientific Laboratory report LA-5595-MS (April 1974).

22. W. D. Purtymun, W. H. Adams, and J. W. Owens, "Water Quality in Vicinity of the Fenton Hill Site, 1974," Los hlamos Scientific Laboratory report LA-6093 (December 1975).

23. W. C. Hanson and F, R, Niera, Jr.. "Long-Term Ecological sffect of Exposure to Uranium," Los Alamos Scientific Laboratory report LA-6269-MS (1976).

24. H. L. Cannon, "The Effect of UraniumVanadium Deposits on the Vegetation of the Colorado Plateau," Amer. Jour. of Sci.. 250:735-770 (1952).
25. W. H. Kingsley, "Survey of Los Alamos and Pueblo Canyon for Radioactive Contamination and Radioassay Tests Run on Sewer Water Samples and Water and Soil Samples Taken from Los Alamos and Pueblo Canyons," Les Alamos Scientific Laboratory report LAMs-516 (1947).

26. W. D. Purtymun, "Storm Runoff and Transport of Radionuclides in DP Canyon, Los Alamos County, New Mexico," Los Alamos Scientific Laboratory report LA-5744 (1974).

27. T. E. Hakonson, J. W. Nyhan, and W. D. Purtymun, "Accumulation and Transport of Soil Plutonium in Liquid Waste Discharge Areas at Los Alamos," IAEA Symposium on Transuranic Nuclides in the Envi.ronment, IAEA-SM-199/99 (in press). 
TABLI: I

MEANS AND EXTRRMES OF TEM'ERHTURE AND PREcIPITATION

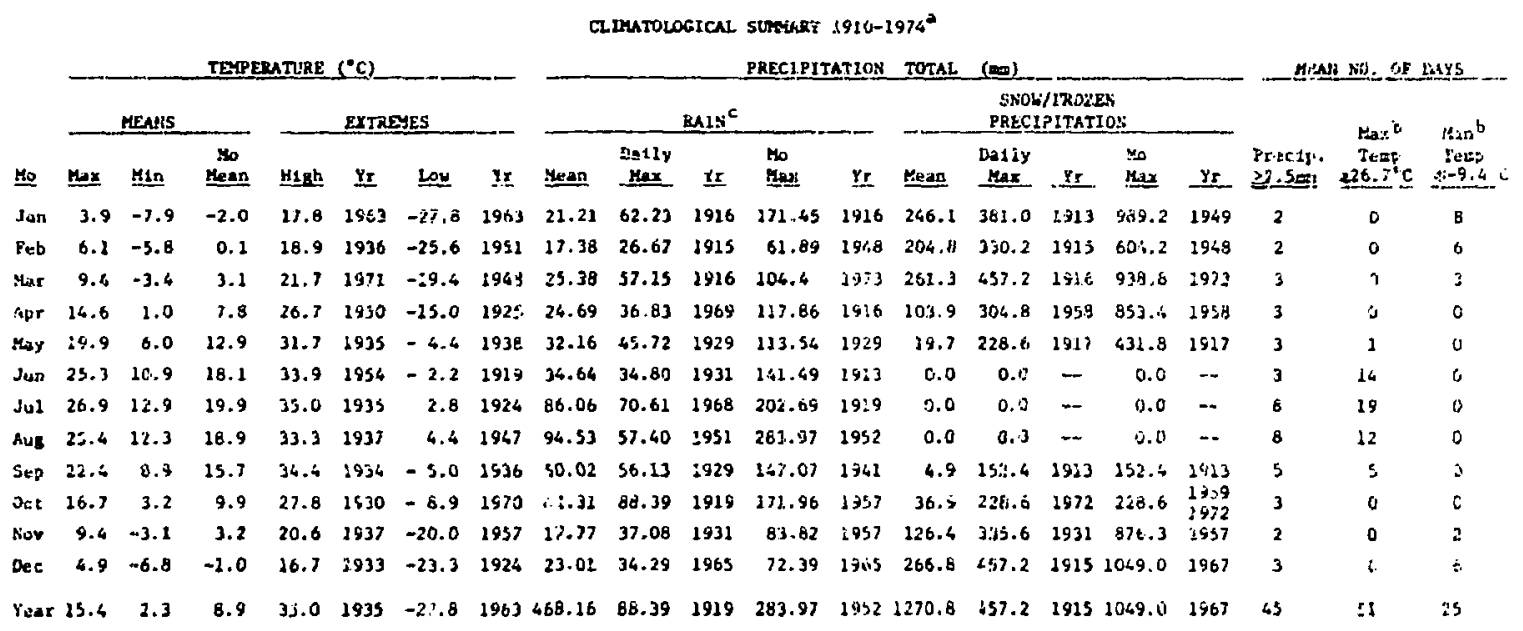

Cr.IMATOLOFICA1. SLYMAKY $1975^{\mathrm{a}}$

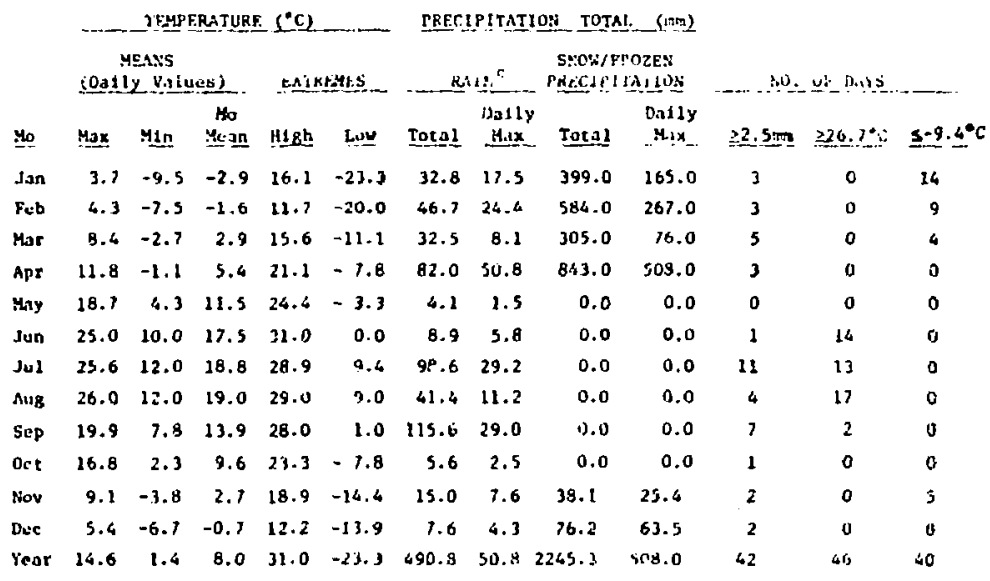

"Jas Manos. Neu Mexico; latltude $35^{\circ} 32^{\prime}$ North, longltude $106^{\circ} 19^{\circ}$ Hesti Elevation 2260 m.

${ }^{2} 26.3^{\circ} \mathrm{C}=80^{\circ} \mathrm{F} ;-9.4^{\circ} \mathrm{C}$ a $15^{\circ} \mathrm{F}$.

Tncluden liquid unter equivalent of frozen preciptation. 
UNITS OF MEASURENENT CONVERSIONS

Quane1cy

Radloact1vity Concentrations

Alrborne

In Liquids

In Sol1ds

\section{This Report}

ERDAM 0524

$=10^{-12} \mu \mathrm{Ci} / \mathrm{ml}=10^{-12} \mu \mathrm{CI} / \mathrm{ml}$

$=10^{-15} \mu \mathrm{CA} / \mathrm{m} \ell=10^{-15} \mu \mathrm{CI} / \mathrm{m \ell}$

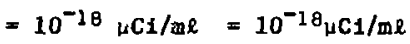

$=10^{-9} \mu \mathrm{C} 1 / \mathrm{ml}=10^{-9} \mu \mathrm{Cl} / \mathrm{ml}$

$=10^{-12} \mu \mathrm{Ci} / \mathrm{ml}=10^{-12} \mu \mathrm{Ci} / \mathrm{ml}$

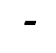

$-$
Internationel (SI)

Common U日age

$=0.037 \quad \mathrm{~s}^{-1} \mathrm{~m}^{-3}=1 \quad \mathrm{pC} 1 / \mathrm{m}^{3}$

$=3.7 \times 10^{-5} \mathrm{~s}^{-1 \mathrm{~m}^{-3}}-10^{-3} \mathrm{pC} 1 / \mathrm{m}^{3}$

$=3.7 \times 10^{-8} \mathrm{~s}^{-1} \mathrm{~m}^{-3}=10^{-6} \mathrm{pC} 1 / \mathrm{m}^{3}$

$=37$

$\mathrm{s}^{-1} \mathrm{~m}^{-3}=1 \quad \mathrm{pCl} / 2$

$=0.037$

$\mathrm{s}^{-1} \mathrm{~m}^{-3}=10^{-3} \mathrm{pCi} / \mathrm{e}$

$=37$

$\mathrm{s}^{-1} \mathrm{~kg}^{-1}=1 \mathrm{pCl} / \mathrm{g}$

$=0.037$

$$
\mathrm{s}^{-1} \mathrm{~kg}^{-1}=10^{-3} \mathrm{pC} 1 / \mathrm{s}
$$

Chemlcal Properíles

Concentrations in Liguids

$$
\begin{aligned}
& 1 \mathrm{mg} / \mathrm{l} \\
& 1 \mathrm{\mu g} / \mathrm{l} \\
& 1 \mathrm{ng} / \mathrm{l}
\end{aligned}
$$

Exchange Capacity

Electrical Conductance

Fluid Fluw Rates

$1 \mathrm{eq} / \mathrm{kg}$

$1 \mathrm{~ms} / \mathrm{m}$

$1 \mathrm{~m}^{3} / \mathrm{s}$

$1 \ell / \mathrm{s}$

Meteorolog1cal Data

Temperature

Precipitation

Wind Speed

Alr Pressure
${ }^{\circ} \mathrm{C}$

$1 \mathrm{man}$

$1 \mathrm{~m} / \mathrm{s}$

$1 \mathrm{kPa}$

$\begin{aligned}- & =1 \mathrm{~g} / \mathrm{m}^{3} \\ - & =1 \mathrm{mg} / \mathrm{m}^{3} \\ -\quad & =1 \mu \mathrm{g} / \mathrm{m}^{3} \\ - & =1 \text { (equivalen } \\ -\quad & =1 \mathrm{mS} / \mathrm{m} \\ -\quad & =1 \mathrm{~m}^{3} / \mathrm{s} \\ & =1 \mathrm{dm} / \mathrm{s} \\ -\quad & K={ }^{\circ} \mathrm{C}+273.15 \\ -\quad & =1 \mathrm{~mm} \\ -\quad & =1 \mathrm{~m} / \mathrm{s} \\ & =1 \mathrm{kPa}\end{aligned}$

- 1 ppm

- 1 ppb

- $10^{-3} \mathrm{ppb}$

- $10^{2} \mathrm{meq} / 100_{\mathrm{g}}$

- 10 umho/cm

- $6 \times 10^{4} \mathrm{epm}$

- $2120 \mathrm{cfm}$

- $60 \mathrm{kpw}$

- $\quad 2.12$ sfm

\section{Geological Data}

Weter Volume

Discharge

$1 \mathrm{~m}^{3}$

$1 \mathrm{R} / \mathrm{s}$

$1 \mathrm{~m}^{3} / \mathrm{s}$
$-1 \mathrm{~m}^{3}$

$=1 \mathrm{dm}^{3} / \mathrm{s}$

$=1 \mathrm{n}^{3} / \mathrm{s}$

$$
\begin{aligned}
-\mathrm{F} & =1.8\left({ }^{\circ} \mathrm{C}\right)+32 \\
& =0.039 \mathrm{inch} \\
& =2.237 \mathrm{mph} \\
& =9.87 \times 10^{-3} \text { atmos. } \\
& =20 \mathrm{mbar} \\
& =0.145 \mathrm{pal} \\
& =0.295 \mathrm{in} . \mathrm{Hg}
\end{aligned}
$$

$=8.11 \times 10^{-4} \mathrm{BC} . \mathrm{ft}$

- 0.0353 ef s

$=15.9 \mathrm{gpm}$

$-2.28 \times 10^{4} \mathrm{gpd}$

- $35.3 \mathrm{cfs}$

$=1.59 \times 10^{4} \mathrm{gpm}$

$-2.28 \times 10^{7} \mathrm{Bpd}$

$-100 \mathrm{rad}$

$.2 .70 \times 10^{-11} \mathrm{ci}_{\mathrm{I}}$ rad, rem

Ci
Gy (gray)

Bq (bequerel) 
MINIMUM DETECTION LIMITS (MDLS) EOR ROUTINE ANALYSES OF RADIOACTIVITY IN TYPICAL ENVIRONMTNTAL SAMPLES

Analysis

${ }^{3} \mathrm{H}$ (oxide)
${ }^{1{ }^{7}} \mathrm{Cs}$
${ }^{23}{ }^{8} \mathrm{Pu}$
${ }^{239} \mathrm{Pu}$
Gross $\alpha$
Gross 8
Grose $\gamma$
$U$ (total)

Alrborne

$5 \times 10^{-12} \mu \mathrm{CA} / \mathrm{ml}$

$10 \times 10^{-18} \mu \mathrm{Cl} / \mathrm{ml}$

$10 \times 10^{-1 \mathrm{~B}} \mathrm{\mu C1} / \mathrm{m} 8$.

$0.05 \times 10^{-15} \mu \mathrm{Cl} / \mathrm{ar} 2$

$0.1 \times 10^{-15} \mu \mathrm{Cl} / \mathrm{ml}$

$0.01 \mathrm{ng} / \mathrm{m}^{3}$
L1quids

$0.6 \times 10^{-6} \mu \mathrm{Cl} / \mathrm{ml}$

$0.1 \times 10^{-6} \mu G 1 / m l$

$0.1 \times 10^{-9} \mu \mathrm{CL} / \mathrm{mf}$

$0.1 \times 10^{-9} \mu \mathrm{Cl} / \mathrm{ml}$

$0.5 \times 10^{-9} \mu \mathrm{CI} / \mathrm{ER}$

$1 \times 10^{-9} \mu \mathrm{Cl} / \mathrm{ml}$

$0.2 \times 10^{-6} \mathrm{\mu C1} / \mathrm{ml}$

$1 \mu \mathrm{g} / \mathrm{l}$
Solids

$\begin{array}{ll}0.6 \mathrm{nC1} / \mathrm{l}^{a} \\ 0.2 \mathrm{pCI} / \mathrm{g} \\ 5 & \mathrm{fCl} / \mathrm{g} \\ 5 & \mathrm{fCl} / \mathrm{g} \\ 1 & \mathrm{pCl} / \mathrm{g} \\ 2 & \mathrm{pCI} / \mathrm{g} \\ 0.4 & \mathrm{pC}=1 / \mathrm{g} \\ 1 & \mathrm{ng} / \mathrm{g}\end{array}$

$0.6 \mathrm{nC} 1 / l^{a}$

$5 \mathrm{fCl} / \mathrm{s}$

$5 \mathrm{fCl} / \mathrm{s}$

$1 \mathrm{pCi} / \mathrm{g}$

$0.4 \mathrm{pC}=1 \mathrm{~g}$

$1 \mathrm{ng} / \mathrm{g}$

\footnotetext{
anly the tritium contained in the unbound water of the sample is analyzed.

botal mass concencrations of urantum are determfned fluorometrically; conversion to activity depends on the isotopic composition of the material.
} 
TABLE IV

BRDA RADHOACTIYITY CONCENTRATION GUIDES (CGs)

CONCENTRATION GULDES FOR UACONTROLLLED AREAS

CG for A1r

Nuel1de

${ }^{3} \mathbf{H}$

${ }^{89} \mathrm{Sr}$

$90_{\mathrm{Sr}} \mathrm{c}$

191.1

$197 \mathrm{Ca}$

$238 \mathrm{Pu}$

$239 \mathrm{Pu}$

$241_{\text {AII }}$

v. natural ${ }^{b}$

Nucl1de

${ }^{3} \mathbf{H}$

${ }^{89} \mathrm{Sr}$

${ }^{90} \mathrm{Sr}^{\mathrm{C}}$

$13 I_{1}$

$137 \mathrm{Cs}$

${ }^{298} \mathrm{Pu}$

$2{ }^{9} \mathrm{Pu}^{\mathrm{C}}$

241 Am

v, natura ${ }^{b}$

\begin{tabular}{|c|c|}
\hline$\left(\mu C_{1} / m l\right)$ & $\left(p C_{1} / \mathrm{m}^{3}\right)$ \\
\hline $2 \times 10^{-7}$ & $2 \times 10^{5}$ \\
\hline $3 \times 10^{-16}$ & 300 \\
\hline $3 \times 10^{-12}$ & $3 a$ \\
\hline $1 \times 10^{-10}$ & 30 \\
\hline $2 \times 10^{-3}$ & 2000 \\
\hline $7 \times 10^{-14}$ & 0.0 \\
\hline $6 \times 10^{-14}$ & 0.06 \\
\hline $2 \times 10^{-13}$ & 0.2 \\
\hline $3 \times 10^{-12}$ & $\frac{\left(\mu \mathrm{g} / \mathrm{m}^{3}\right)^{b}}{9}$ \\
\hline
\end{tabular}

CG for Water

$\begin{array}{cc}(\mu \mathrm{C} 1 / \mathrm{m} 2) & (\mathrm{\Omega C} 1 / \ell) \\ 3 \times 10^{-3} & 3000 \\ 3 \times 10^{-6} & 3 \\ 3 \times 10^{-7} & 0.3 \\ 3 \times 10^{-7} & 0.3 \\ 3 \times 10^{-5} & 20 \\ 5 \times 10^{-6} & 5 \\ 5 \times 10^{-6} & 5 \\ 4 \times 10^{-6} & 4 \\ 2 \times 10^{-5} & \frac{(\mathrm{m} / \mathrm{l} / \mathrm{l}}{6}\end{array}$

CONCENTRATION GUIDES FOR CONTROLLED AREAS

CG for Alr

\begin{tabular}{|c|c|}
\hline$\left(\mu C_{1} / \mathrm{m} \ell\right)$ & $\left(\mathrm{p} C 1 / \mathrm{m}^{3}\right)$ \\
\hline $5 \times 10^{-6}$ & $5 \times 10^{6}$ \\
\hline $3 \times 10^{-}$ & $3 \times 10$ \\
\hline $1 \times 10^{-9}$ & 1000 \\
\hline $4 \times 10^{-9}$ & 4000 \\
\hline $6 \times 10^{-8}$ & $6 \times 10^{4}$ \\
\hline $2 \times 10^{-12}$ & 2 \\
\hline $2 \times 10^{-12}$ & 2 \\
\hline $6 \times 10^{-12}$ & 6 \\
\hline $7 \times 10^{-21}$ & $\frac{\left(\mu g / m^{3}\right)}{210}$ \\
\hline
\end{tabular}

CG For Tater

\begin{tabular}{|c|c|}
\hline$\left(\mu C_{1} / m l\right)$ & $(\mathrm{nC1} / \mathrm{l})$ \\
\hline $1 \times 10^{-1}$ & $1 \times 10^{5}$ \\
\hline $3 \times 10$ & 300 \\
\hline $1 \times 10^{-5}$ & 10 \\
\hline $3 \times 10^{-5}$ & 30 \\
\hline $4 \times 10^{-4}$ & 400 \\
\hline $1 \times 10^{-4}$ & 100 \\
\hline $1 \times 10^{-4}$ & 100 \\
\hline $1 \times 10^{-4}$ & 100 \\
\hline $5 \times 10^{-4}$ & $\frac{(\mathrm{mg} / \mathrm{l})}{1500}$ \\
\hline
\end{tabular}

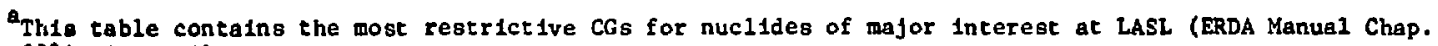
0524, Annex A).

bFluorometric meaguretrents of U mass may be converted to the ERDA "speclal curle" using the factor 0.33 $\mu \mathrm{C} \$ \mathrm{~B}$.

cof the posolble radianuclides released at LASL, ${ }^{90} \mathrm{Sr}$ and ${ }^{239} \mathrm{Pu}$ are the most restrictive. The cGs for these pocies are used for the gross-beta and gross-alpha CGe; respectively. 
UATER STANDARDS

DRINKING WATER STANDARDS FOR CHEMICALS

Concentration Linit (mg/l)

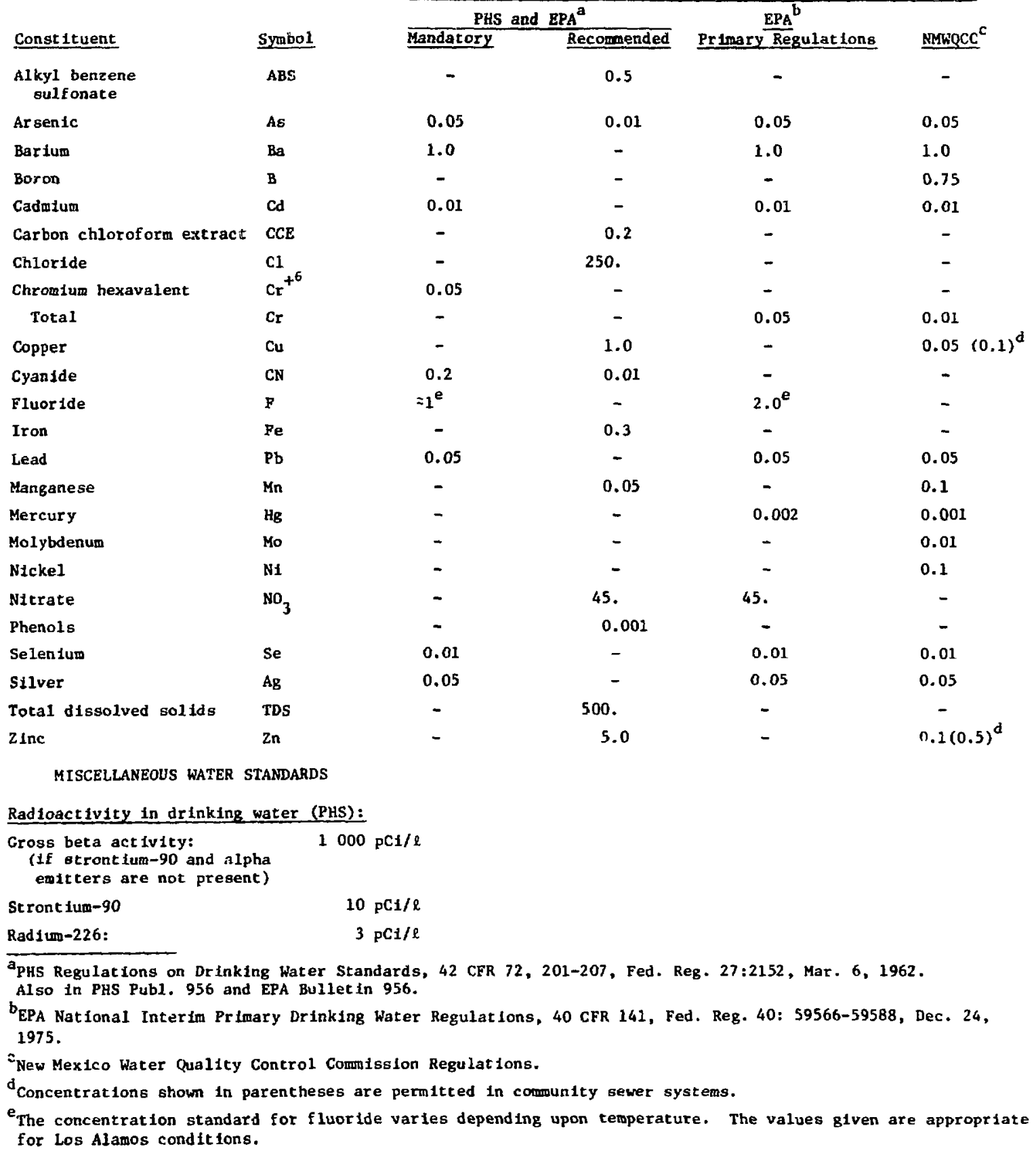


TABLE VI

ATMOSPHERIC RADIOACTIVE EFTLUENT TOTALS FOR 1975

\begin{tabular}{|c|c|c|c|c|c|c|c|c|}
\hline Location & $\begin{array}{l}{ }^{238} \mathrm{Pu} \\
{ }^{239} \mathrm{Pu}_{\mathrm{Pu}} \\
(\mu \mathrm{Cl})\end{array}$ & $\begin{array}{l}2333_{\mathrm{U}} \\
235_{\mathrm{U}} \\
238_{\mathrm{U}} \\
(\mathrm{\mu C1}) \\
\end{array}$ & $\begin{array}{l}{ }^{234} \mathrm{Th} \\
\text { (mc1) }\end{array}$ & $\begin{array}{l}\mathrm{MFP}^{\mathrm{a}} \\
(\underline{\mu \mathrm{C} 1)})\end{array}$ & $\begin{array}{l}131_{1} \\
\text { (nc1) }\end{array}$ & $\begin{array}{l}{ }^{41} \mathrm{Ar} \\
\text { (C1) }\end{array}$ & $\begin{array}{c}3{ }_{p} \\
(\mu C 1)\end{array}$ & $\begin{array}{r}{ }^{3} \mathrm{H} \\
\text { (C1) }\end{array}$ \\
\hline TA-2 & - & - & - & - & - & 237 & - & - \\
\hline TA-3 & 211 & 194 & 6.6 & 184 & 1.4 & - & - & 22 \\
\hline$T A-9$ & - & - & - & - & - & - & - & - \\
\hline TA-15 & - & - & - & - & - & - & - & - \\
\hline$T A-21$ & 11.1 & 721 & - & 1.4 & - & - & - & 306 \\
\hline$T A-33$ & - & - & - & - & - & - & - & 3478 \\
\hline TA-35 & 5.9 & - & - & - & - & - & - & 2394 \\
\hline$T A-41$ & - & - & - & - & - & - & - & - \\
\hline$T A-43$ & 1.7 & - & - & - & - & - & 49 & - \\
\hline$T A-46$ & - & 0.5 & - & - & - & - & - & -. \\
\hline$I A-48$ & 12.3 & 3.9 & - & 722 & - & - & - & - \\
\hline TA-50 & 4.1 & - & - & 42 & - & - & - & - \\
\hline
\end{tabular}

$\overline{\text { Mixed Fission Products. }}$ 
TABLE VII

ANNUAL. THERMOLUMINESCENT DOS DMETER MEASURDNENTS

Station Location

Off-Sice Stactons

1 Barranca School Arkansss Avenue Golf Course

Cumbres School

Pajartico Sk1 Area

Diamond Drtue

$48 \mathrm{th}$ Street

Fullec Lodge

'Antte Rock ST?

15 Espanola

11 Pofoaque

12 Santa $\mathrm{Fe}$

Perimeter Stat lons

13 I. A Airport

Bayi: STP

Acorn Street

State Hwy 4

TA-6

We11 PM-i

TA-16

TA-49

Booster P-1

Pajartto Acres

Bandeller Lookout

On-Sice Stations

24 TA-21

$\mathrm{TA}-2$ (A)

TA-2 (B)

TA-2 (C)

TA-53 (A)

TA-53 (B)

TA-53 (C)

TA-53 (D)

$T A-53$ (E)

TA-53 (F)

TA-3 (A)

$T A-3$ (B)

$T A-3$ (C)

TA-3 (D)

TA-52

TA-18 (A)

TA-18 (B)

$T A-18$ (C)

TA-18 (D)

TA-18 (E)

TA-33
Coordinates

Exposure Pertod

N? 80 E130

N170 B020

N160 E060

N150 E090

N130 1180

$N 130$ E020

N110 E000

N110 E090

$5090 \mathrm{E} 430$

-

\author{
(weeks)
}

Annual Dose

(area/yr)

$128( \pm 4)$

$132( \pm 8)$

$126( \pm 8)$

$152( \pm 10)$

$117( \pm 8)$

$120( \pm 9)$

$142( \pm 5)$

$140( \pm 4)$

$125( \pm 4)$

$101( \pm 5)$

$95( \pm 6)$

$104( \pm 7)$

N110 E160

N110 E260

N100 E110

N070 E350

N060 W050

N030 E310

S030 W080

$\$ 100$ E040

$\$ 100$ E300

$\$ 210$ E370

$\$ 270$ E200

NO90 E170

N080 E100

N080 E120

N080 E1.10

N070 E160

N060 E190

NO60 E200

N060 E22O

N050 E230

N040 E230

NO5O E010

N060 E010

N0SO E020

N050 E040

N020 E170

S040 E190

S030 E190

S040 E200

S060 E190

S050 E170

S250 E230
$131( \pm 6)$

$134( \pm 8)$

125 ( \pm 4$)$

$197( \pm 18)$

$125( \pm 6)$

$148( \pm 8)$

$130( \pm 4)$

$128( \pm 4)$

$131( \pm 6)$

$98( \pm 8)$

128 ( \pm 11$)$
$128( \pm 6)$

$150( \pm 5)$

$172( \pm 5)$

$135( \pm 4)$

$126( \pm 5)$

$146( \pm 4)$

$135( \pm 5)$

$292( \pm 5)$

$144( \pm 4)$

$138( \pm 5)$

$964( \pm 9)$

$252( \pm 6)$

$164( \pm 4)$

$141( \pm 4)$

$113( \pm 5)$

$199( \pm 4)$

$140( \pm 5)$

$413( \pm 6)$

$162( \pm 5)$

$186( \pm 5)$

$136( \pm 4)$ 


\section{TABLE VIII}

SUMARY OF ANNUAL ATMOSPHERIC RADIOACTIVITY MONITORING

Number and
Type of Sampling
Locactons

\section{1 off-sice \\ 10 perimster}

5 on-site
11 off-site
10 perimeter
5 on-site

11 off-B1te

10 perimeter

5 on-site

11 off-site

10 perimeter

5 on-yite

11 off-site

10 perimeter

5 onsstie

11 off-Bite

10 perimeter

5 on-alte

4 off-site

5 perimeter

2 on-site

\section{Type of \\ Analysis \\ Performed}

\section{gross a \\ gross a}

gross a

gross $\beta$

gross $B$

gross $B$

tri:lated $\mathrm{H}_{2} \mathrm{O}$

tritiated $\mathrm{H}_{2} \mathrm{O}$

tritlated $\mathrm{H}_{2} \mathrm{O}$

$238_{\mathrm{Pu}}$

$238 \mathrm{Pu}$

${ }^{238} \mathrm{Pu}$

${ }^{239} \mathrm{Pu}$

$239_{\mathrm{Pu}}$

${ }^{239} \mathrm{Pu}$

$$
\begin{aligned}
& \text { uranium } \\
& \text { urantum } \\
& \text { uran fum } \\
& 241_{\mathrm{Am}} \\
& 241_{\mathrm{Am}} \\
& 241_{\mathrm{Am}}
\end{aligned}
$$

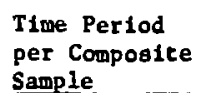

Sample

2 week
2 week
2 week
2 week
2 week
2 week

2 week

2 week

2 week

b to 8 week

6 to 8 week

6 to 8 week

6 to 8 week

6 to 8 week

6 to 8 week

\begin{abstract}
3 month
3 month

3 month
\end{abstract}

3 monch

3 month

3 month

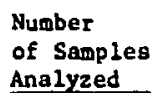

Mean

Rad losctivity

Concentrat 10 n

$\underline{\mathbf{Z} C G}$

$\begin{array}{lll}285 & 1.0 \times 10^{-15}{ }_{\mu C 1 / m l} & 1.8 \\ 259 & 1.1 \times 10^{-15}{ }_{\mu C 1 / m l} & 1.9 \\ 130 & 1.1 \times 10^{-15}{ }_{\mu C 1 / m L} & 0.1 \\ & & \\ 285 & 76 \times 10^{-15}{ }_{\mu C 1 / m \ell} & 0.3 \\ 259 & 80 \times 10^{-1 S{ }_{\mu C L} / \mathrm{ml}} & 0.3 \\ 130 & 77 \times 10^{-15_{\mu C 1 / m R}} & 0.01\end{array}$

284

$20 \times 10^{-12}{ }_{\mu \mathrm{Cl}} / \mathrm{ml}$

0.01

259

129

$42 \times 10^{-12}{ }_{\mu C 1 / 0 l}$

0.02

$104 \times 10^{-12} \mu \mathrm{Cl} / \mathrm{me}$

0.002

88

$0.8 \times 10^{-18} \mu \mathrm{Cl} / \mathrm{mL}$

0.001

80

$0.6 \times 10^{-18} \mu \mathrm{CL} / \mathrm{mL}$

0.001

40

$0.5 \times 10^{-18} \mu \mathrm{Cs} / \mathrm{ml}$

0.00003

88

$19 \times 10^{-18}{ }_{\mu \mathrm{Cl}} / \mathrm{ml}$

0.03

$24 \times 10^{-18} \mathrm{HC1} / \mathrm{ml}$

0.04

$20 \times 10^{-18} \mathrm{HCl} / \mathrm{ml}$

0.001

40

44

40

20

$$
\begin{aligned}
& 45 \mathrm{pg} / \mathrm{m}^{3} \\
& 37 \mathrm{pg} / \mathrm{m}^{3} \\
& 45 \mathrm{pg} / \mathrm{m}^{3}
\end{aligned}
$$

0.0005

0.0004

0.00002

$4 \times 10^{-18} \mathrm{NCs} / \mathrm{ml}$

0.002

$8 \times 10^{-18} \mathrm{uCL} / \mathrm{mL}$

0.004

$5 \times 10^{-18} \mu \mathrm{Cl} / \mathrm{ml}$

0.0001 
ANNUAL ATMOSPHERIC TRITIATED WATER VAPOR CONCEMTRATIONS

\begin{tabular}{|c|c|c|c|c|c|}
\hline \multirow{2}{*}{\multicolumn{2}{|c|}{ Stat Ion Location }} & \multirow[b]{2}{*}{ Coordinates } & \multicolumn{3}{|c|}{ Concentration $\mathrm{PC} / \mathrm{C}^{3}\left(10^{-12} \mathrm{\mu C1/ml)}\right.$} \\
\hline & & & Maximum & Mean & $\underline{\mathbf{z} C G}$ \\
\hline \multicolumn{6}{|c|}{ Off-Site Stations } \\
\hline & Barranca School & N180 E130 & 41 & $14( \pm 1)$ & 0.01 \\
\hline 2 & Arkangas Avenue & N170 E 20 & 76 & $18( \pm 1)$ & 0.01 \\
\hline 3 & Golf Course & $N 160$ E 60 & 70 & $22( \pm 2)$ & 0.01 \\
\hline & Cumbres School & N150 E 90 & 83 & $25( \pm 2)$ & 0.01 \\
\hline & Dlamond Drive & N130 E 20 & 81 & $27( \pm 2)$ & 0.01 \\
\hline 6 & $48 \mathrm{th}$ Street & N110 E 0 & 62 & $20( \pm 1)$ & 0.01 \\
\hline 7 & Fuller Lodge & N110 E 90 & 93 & $28( \pm 2)$ & 0.01 \\
\hline 8 & White Rock STP & S $90 \quad E 430$ & 57 & $25( \pm 2)$ & 0.01 \\
\hline 9 & Espanola & & 42 & $13( \pm 1)$ & 0.01 \\
\hline 10 & Pojoaque & & 38 & $14( \pm 2)$ & 0.01 \\
\hline 11 & Santa Fe & & 35 & $24( \pm 1)$ & 0.01 \\
\hline \multicolumn{6}{|c|}{ Perimeter Stations } \\
\hline & L. A. Airport & N110 E160 & 724 & $88( \pm 6)$ & 0.04 \\
\hline & Bayo STP & N110 E260 & 84 & $29(=2)$ & 0.001 \\
\hline & Acorn Street & N100 E110 & 314 & $64( \pm 4)$ & 0.03 \\
\hline 15 & $T A-6$ & N $60 \times 50$ & 69 & $22( \pm 2)$ & 0.0004 \\
\hline 16 & Well PM-1 & $N 30 \mathrm{E} 310$ & 1.23 & $48 \div \pm 31$ & 0.001 \\
\hline 17 & $T A-16$ & S 30 W 80 & 44 & $18( \pm 2)$ & 0.01 \\
\hline 18 & $T A-49$ & $\$ 100 \mathrm{E} 40$ & 67 & $21( \pm 2)$ & 0.0004 \\
\hline 19 & Booster P-1 & $\$ 100 E 300$ & 109 & $49( \pm 3)$ & 0.001 \\
\hline 20 & Pajarito Acres & 5210 E370 & 48 & $24( \pm 2)$ & 0.01 \\
\hline 21 & Bandel ler Lookout & $\mathrm{s} 270 \mathrm{E} 200$ & 218 & $61(.5)$ & 0.03 \\
\hline \multicolumn{6}{|c|}{ Un-Site Stations } \\
\hline 22 & TA-21 & N 90 E170 & 208 & $64( \pm 4)$ & 0.001 \\
\hline 23 & LAMPF & N $60 E 190$ & 208 & $71( \pm 4)$ & 0.001 \\
\hline 24 & $T A-52$ & N 20 E170 & 592 & $174( \pm 12)$ & 0.003 \\
\hline 25 & Booster P-2 & S 30 E190 & 229 & $54( \pm 3)$ & 0.001 \\
\hline 26 & TA-33 & $S 250 \varepsilon 230$ & 949 & $156( \pm 17)$ & 0.003 \\
\hline
\end{tabular}


TABLE $X$

ANIUAL ATMOSPHERIC GROSS-ALPHA AND GROSS-BETA ACTIVITY CONCENTRATIQAS

Scaction Locátion

Gross-Alpha Concentrations

$\underline{\mathrm{fC} 1 / \mathrm{m}^{3}\left(10^{-15} \mu \mathrm{C} 1 / \mathrm{ml}\right)}$

Coordinates Max Min Mean Xcc
Grose-Becc Concentrations $\underline{\mathrm{EC}} / \mathrm{m}^{3}\left(10^{-15} \mathrm{nat} / \mathrm{m} / \mathrm{L}\right.$ Max Min Mean $\underline{\text { XCG }}$

\section{off-Site Stations}

1 Barranca School
2 Arkangas Avenue
3 Golf Courge
4 Cumbres School
5 Diamond Drive
6 48ch Street
7 Fuller Lodge
8 White Rock STP
9 Espanola
10 Pojoaque
11 Sanca Fe

$\begin{array}{ccccccccc}\text { N180 E130 } & 1.6 & 0.4 & 1.1( \pm 0.1) & 1.8 & 195 & 12 & 78( \pm 4) & 0.3 \\ \text { N170 E 20 } & 1.7 & 0.5 & 1.0( \pm 0.1) & 1.7 & 211 & 13 & 75( \pm 4) & 0.3 \\ \text { N160 E 60 } & 1.7 & 0.7 & 1.0( \pm 0.1) & 1.7 & 212 & 10 & 80( \pm 5) & 0.3 \\ \text { N150 E 90 } & 1.5 & 0.4 & 1.0( \pm 0.1) & 1.7 & 218 & 13 & 71( \pm 4) & 0.2 \\ \text { N130 E 20 } & 2.3 & 0.5 & 1.1( \pm 0.1) & 1.8 & 227 & 13 & 78( \pm 4) & 0.3 \\ \text { N110 E } 0 & 1.7 & 0.5 & 1.0( \pm 0.1) & 1.7 & 195 & 12 & 75( \pm 4) & 0.3 \\ \text { N110E 90 } & 1.7 & 0.6 & 1.0( \pm 0.1) & 1.7 & 209 & 11 & 74( \pm 4) & 0.2 \\ \text { S 90 E430 } & 1.8 & 0.6 & 1.1( \pm 0.1) & 1.8 & 205 & 12 & 77( \pm 4) & 0.3 \\ - & 1.9 & 0.6 & 1.0( \pm 0.1) & 1.7 & 198 & 15 & 75( \pm 4) & 0.3 \\ - & 1.6 & 0.7 & 1.1( \pm 0.1) & 1.8 & 190 & 13 & 77( \pm 4) & 0.3 \\ - & 1.8 & 0.5 & 1.1( \pm 0.1) & 1.8 & 226 & 13 & 72( \pm 4) & 0.2\end{array}$

\section{Pertmeter Stat lons}

12 L. A. Alrport

13 Bayo STP

14 Acorn Streer

$15 T A-6$

16 We11 PM-1

17 TA-16

$18 \quad T A-49$

19 Booster P-1

20

21

21 Bandeller Lookout

\section{On-stte Stactone}

$\begin{array}{ll}22 & \text { TA-21 } \\ 23 & \text { LAMPF } \\ 24 & \text { TA-32 } \\ 25 & \text { Boosier P-2 } \\ 26 & \text { TA-33 }\end{array}$

26 TA-33

$\begin{array}{lllllllll}\text { N110 E160 } & 2.0 & 0.6 & 1.2( \pm 0.1) & 2.0 & 245 & 13 & 84( \pm 4) & 0.3 \\ \text { N110 E260 } & 2.5 & 0.4 & 1.1( \pm 0.1) & 0.1 & 190 & 13 & 74( \pm 4) & 0.01 \\ \text { N110 E110 } & 1.8 & 0.5 & 1.1( \pm 0.1) & 1.8 & 205 & 13 & 77( \pm 4) & 0.3 \\ \text { N 60 W 50 } & 2.6 & 0.6 & 1.2( \pm 0.1) & 0.1 & 214 & 13 & 79( \pm 4) & 0.01 \\ \text { N } 30 \text { E310 } & 1.9 & 07 & 1.2( \pm 0.1) & 0.1 & 223 & 13 & 83( \pm 4) & 0.01 \\ \text { S 30 W 80 } & 1.4 & 0.6 & 1.0( \pm 0.1) & 1.7 & 200 & 11 & 74( \pm 4) & 0.2 \\ \text { S100E 40 } & 1.8 & 0.4 & 1.1( \pm 0.1) & 0.1 & 256 & 15 & 84( \pm 4) & 0.01 \\ \text { S100 E300 } & 1.9 & 0.5 & 1.1( \pm 0.1) & 0.1 & 213 & 15 & 78( \pm 4) & 0.01 \\ \text { S210 E370 } & 2.2 & 0.6 & 1.2( \pm 0.1) & 2.0 & 189 & 13 & 81( \pm 4) & 0.3 \\ \text { S270 E200 } & 2.2 & 0.5 & 1.2( \pm 0.1) & 2.0 & 235 & 13 & 06( \pm 4) & 0.3\end{array}$

$\begin{array}{lllllllll}\text { N } 90 E 170 & 1.5 & 0.5 & 1.0( \pm 0.1) & 0.1 & 236 & 9 & 73( \pm 4) & 0.01 \\ \text { N } 60 \text { E190 } & 1.7 & 0.5 & 1.1( \pm 0.1) & 0.1 & 186 & 15 & 77( \pm 4) & 0.01 \\ \text { N } 20 \text { E170 } & 2.0 & 0.5 & 1.2( \pm 0.1) & 0.1 & 212 & 12 & 00( \pm 4) & 0.01 \\ \text { S } 30 E 190 & 1.8 & 0.5 & 1.1( \pm 0.1) & 0.1 & 225 & 1 . & 77( \pm 4) & 0.01 \\ \text { S250E230 } & 2.0 & 0.4 & 1.2( \pm 0.1) & 0.1 & 199 & 15 & 78( \pm 4) & 0.01\end{array}$


TABLE XI

amnual athospheric ${ }^{238} \mathrm{Pu},{ }^{239} \mathrm{Pu}$. ANd ${ }^{241}$ Am concentrations

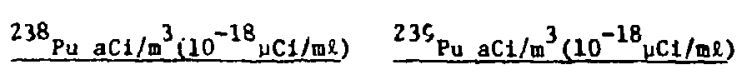

Station Location

Off-Sice Stations

1 Barranca Schor:

2 Arkansas Avenue

3 Golf Course

4 Cumbres School

5 Diamond arive

648 th Street

7 Fuller Lodge

8 White Rock STP

9 Espanola

10 Pojoaque

1). Santa Fe

\section{Perimeter Stations}

12 L. A. Alrport

13 Bayo STP

14 Acorn Street

15 TA-6

26 Well PM-1

17 TA-16

$18 \quad$ TA-49

19 booster P-1

20 Pajarito Actes

21 Randel ler Lookout

On-Si te Scationa

22 TA-21

23 LAMPF

24 TA-52

25 Booster $\mathrm{P}-2$

$26 \quad \mathrm{TA}-33$

$21( \pm 3) \quad 0.04$

Coordinates
N180 E130
N170 E 20
N160 E 60
N150 E 90
N130 E 20
N210 E 0
N110 E 90
S 90 E430
-
-
-
N110 E160
N110 E260
N100 E110
N 60 W 50
N 60 E310
S 30 W 80
S100 E 40
S100 E300
S210 E370
S270 E200
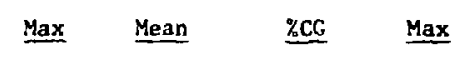

Mean

$\underline{7 \mathrm{CG}}$

${ }^{241} \mathrm{Am} \mathrm{aCl} / \mathrm{m}^{3}\left(10^{-18} \mathrm{HCl} / \mathrm{ml}\right)$

$30.6( \pm 0.7) \quad 0.002$

$0.8( \pm 0.7) \quad 0.001$

$0.4( \pm 0.7) \quad 0.001$

$0.7(\div 0.7) \quad 0.001$

$0.3( \pm 1.0) \quad 0.0004$

$0.7( \pm 0.7) \quad 0.001$

$2.3( \pm 1.2) \quad 0.003$

$0.9( \pm 0.6) \quad 0.001$

$1.0( \pm 1.4) \quad 0.001$

$0.3( \pm 1.0) \quad 0.0004$

$0.4( \pm 1.0) \quad 0.001$

44

$$
21(\leftleftarrows 2)
$$

$20( \pm 2)$

$20( \pm 2)$

$15( \pm 2)$

$20( \pm 2)$

$20( \pm 2)$

$29( \pm 4)$

$18( \pm 2)$

$17( \pm 2)$

$18( \pm 2)$

$16( \pm 2)$

\subsection{4}

0.03

0.03

0.03

0.03

0.03

0.05

0.03

0.03

0.03

0.03

Max

Mean $\quad$ zCG

$\begin{array}{ll}0.6( \pm 0.6) & 0.001 \\ 0.2( \pm 0.5) & 0.00001 \\ 0.9( \pm 0.9) & 0.001 \\ 1.6( \pm 0.7) & 0.0001 \\ 0.3( \pm 0.6) & 0.00002 \\ 0.2( \pm 0.6) & 0.0003 \\ 0.1( \pm 0.7) & 0.00001 \\ 0.8( \pm 0.7) & 0.09004 \\ 0.5( \pm 0.6) & 0.001 \\ 0.3( \pm 0.6) & 0.0004\end{array}$

$24( \pm 4)$

$19( \pm 2)$

0.04

S3( \pm 5$) \quad 0.003$

$20( \pm 2) \quad 0.001$

$19( \pm 2)$

0.03

21( $\$ 2) \quad 0.001$

$22( \pm 2) \quad 0.001$

$21( \pm 2) \quad 0.04$

$23( \pm 2) \quad 0.04$

W $90 \quad E 170$

N 60 E190

N $20 E 170$

S $30 \quad E 190$

$\$ 250 \quad E 230$

$\begin{array}{ll}0.0( \pm 0.6) & 0.000 \\ 1.0( \pm 0.7) & 0.00005 \\ 0.5( \pm 0.8) & 0.00003 \\ 0.5( \pm 0.6) & 0.00003 \\ 0.5( \pm 0.5) & 0.00003\end{array}$

$18( \pm 2)$

$22( \pm 2)$

$21( \pm 2)$

$18( \pm 2)$

$22( \pm 2)$

0.001

0.001

0.001

0.001

0.001

$\begin{array}{ccc}9 & -- & \\ & 3( \pm 2) & 0.0001 \\ 10 & 7( \pm 5) & 0.0001 \\ & -- & \end{array}$


TABLE KII

ANNUAL ATMOSPHERIC URANIUH CONCENTRATIONS

Saclou Locat ion

1 Barranca School

2 Arkansas Avenue

3 Golf Course

4 Cumbres School

5 Diamond Drive

6 48th Street

7 Fuller Lodge

8 White Rock STP

9 Espanola

10 Pojoaque

11 Santa Fe

\section{Perimeter Stations}

12 L. A. Atrport

13 Bayo STP

14 Acorn Street

15 TA-6

16 We 11 PH-1

17 TA-16

18 TA-49

19 Booster $\mathrm{P}-1$

20 Pajarito Acres

21 Bandeller Lookout

\section{On-S1te locations}

$\begin{array}{llr}22 & \text { TA-21 } & \text { N } 90 \text { E170 } \\ 23 & \text { LAMPF } & \text { N } 60 \text { E190 } \\ 24 & \text { TA-52 } & \text { N } 20 \text { E170 } \\ 25 & \text { Booster P-2 } & \text { S } 30 \text { E190 } \\ 26 & \text { TA-33 } & \text { S250 E230 }\end{array}$

Concentration $\left(\mathrm{pg} / \mathrm{Li}^{3}\right)$

\section{Coordinates}

N180 E130

N170 E 20

N160 E 60

N150 E 90

N130E 20

N110 E 0

N110 E 90

S $90 \quad 5430$

--

$-$

--

\section{Max}

71

38

54

73

67

53

66

117

192

139

49

N110 E160

N110 E260

N100 E110

N 60 W 50

N $30 \quad E 310$

S 30 W 80

5100 E 40

$S 100$ E300

$\$ 210 \quad 5370$

S27U E200

\section{9}

60

272

40

58

54

43

60

53

52

Min Mean

\% CC

$\begin{array}{rll}14 & 40( \pm 5) & 0.0004 \\ 8 & 22( \pm 3) & 0.0002 \\ 10 & 32( \pm 4) & 0.0004 \\ 20 & 39( \pm 4) & 0.0004 \\ 12 & 43( \pm 6) & 0.0005 \\ 17 & 39( \pm 5) & 0.0004 \\ 26 & 43( \pm 5) & 0.0005 \\ 14 & 45( \pm 6) & 0.0005 \\ 52 & 95( \pm 11) & 0.001 \\ 31 & 69( \pm 8) & 0.0008 \\ 13 & 28( \pm 3) & 0.0003\end{array}$

$\begin{array}{rrl}54 & 16 & 31(+3) \\ 94 & 22 & 53( \pm 6) \\ 215 & 21 & 72( \pm 10) \\ 73 & 15 & 46( \pm 5) \\ 42 & 9 & 25( \pm 3)\end{array}$

0.0004

0.00002

0.001

0.00001

0.00002

0.000 's

0.00001

0.00002

0.0003

0.0003
U. 000:1

$0.000 \mathrm{is}$

0.00003

0.00002

0.00001 
TABLE XIII

RADTOACTIVITY IN ON-SITE SURFACE AND GROUND WATER

Name and Coordinate

Noneff luent Areas

Canada de 1 Buey

Pajarito Canyon

Water Canyon

Test Well DT-54

Test Well $B$

Ad-Pueblo Canyon Ac id Weir

Pueblo 1

Pueblo 2

Obs. Hole PO-3B

Hanilton Bend Spr.

Pueblo 3

Sand 1a Canyon

SCS-1

DP-Los Alamos Canyon DF: -1

Dys -4

Obs. Hole LAO-C

Obs. Hole LAN-1

Obs. Hole LAO-2

Obs. Hole LAO-3

obs. Hole LAC -4.5

Mortandad Canyon

Gaging Stat toil

Obs. Hole MCO -3

Obs. Hole $\mathrm{MCO}-4$

Obs. Hole MCO-S

Dbs. Hole MCO-6

Obs. Hole MCO-7

Obs. Hole MCO-7.

Obs. Haie MCO-g
No. and ${ }^{3} \mathrm{H}$

Type

N 80 E120

$\times 10$ E150

60

$S 60$ E225

$S 90$ E 85

5110 E 90

N $40 \mathrm{E150}$

mer Release Areal

N130 E $60 \quad 3-5$

130 E 75

N115 E16O

N110 E245

N110 E2 S0

80 E 40

N 55 E155

N $95 \quad E 160$

N 80 E205

N 85 E 70

N 85 E.115

N 80 E205

180 5ils

N 50 E 90

N 45 E 95

N 35 E.135

N 40 E1SO

N 35 El60

N $30 \quad 8170$

v 30 E180

N $30 \mathrm{E} 185$

3-G

$3-5$

(5)

$3-2$

$3-5$

$3-5$
${ }^{3} \mathrm{H}$

$10^{-6} \mathrm{LC} 1 / \mathrm{m} 2$

$24 !$ Am

$10^{-9}{ }^{\circ} C 1 / 0 R$

$-0.7( \pm 2.5)$

$3.3( \pm 4.9)$

$4.8( \pm 5.3)$

$1.3(\div 0.1)$

$0.2( \pm 0.5)$

$-0.16(0.16)$

$-0.09(: 0.16)$

-

$2.3( \pm 2.5) \quad-0.03( \pm 0.20)$

$1.5(: 0.6)$

$0.9( \pm 0.5)$

$5.7(: 1.1)$

$0.02( \pm 0.08)$

$-0.15( \pm 0.04)$

$1.2(\div 0.20)$

$0.9( \pm 1.6)$

$0.08( \pm 0.08)$

$0.9(.0 .8)$

$0.05(: 0.08)$

8.3( \pm 17$)$

$6.8(\div 9.0)$

(2)

$\overline{0}( \pm 0.20)$

)

$-0.01( \pm 0.02$
$0.00( \pm 0.02)$

$76(+200)$

$0.68( \pm 0.69)$

$46(! 100)$
$1.1(\cdot 1.8)$

$11( \pm 7.1)$

$0.29(\leq 0.14)$

$0.08( \pm 0.01)$

$0.12( \pm 0.14)$

$0.26(\div 0.47)$

$35( \pm 100)$

$11( \pm 18)$

$0.18( \pm 0.74)$
$0.26(+0.62)$

$116(\cdot 340)$

$195(\div 570)$

$0.54( \pm 0.39)$

$0.36(+0.34)$

$0.84(+1.48)$

$0.34( \pm 0.69)$

$24( \pm 9.5) \quad 0.47( \pm 0.31)$

$26( \pm 2 i)$

$0.1 .1(1.1)$

$0.9(: 1.4)$

$33( \pm 25)$

$2.4(\div 2.5)$

$2{ }^{38} \mathrm{Pu}$

$10^{-9} \mathrm{LCL}_{\mathrm{L}} / \mathrm{mR}$

$-0.00( \pm 0.01)$

\section{$0.27(\div 0.17)$}

$0.01(\div 0.01)$

$0.02(: 0.07)$

$0.01( \pm 0.01)$

$0.00(0.01)$

$0.00( \pm(.01)$

$125(+410)$

$5.4( \pm 5.9)$

$4.1(\cdot 6.8)$
$239 \mathrm{Pu}$

$10^{-9_{4}} \mathrm{C}_{1 / \mathrm{mL}}$

Gross-a

$10^{-9} \mu \mathrm{Cl} / \mathrm{mP}$

Gross-

$10^{-9}{ }_{\mu} \mathrm{CJ} / \mathrm{ms}$

$3.2(45.0)$

$9.4( \pm 1.5 .7)$

8.2( \pm 8.9$)$

$5.7( \pm 4.9)$

$1.9( \pm 0.9)$

$2.4( \pm 3.8)$

$1.0( \pm 5.0)$

$0.00( \pm 0.01)$

$0.00( \pm 0.04)$

$-0.03( \pm 0.11)$

$61(4100)$

$11( \pm 8.2)$

$17( \pm 10)$

$7.3( \pm 1.6)$

$19( \pm 21)$

$1.1(1$

$1.3( \pm 1.8)$

$0.01( \pm 0.01) \quad 5.5( \pm 20)$

$0.00( \pm 0.02)$

$12( \pm 40)$

$23(19.5)$

$20( \pm 14)$

$0.84( \pm 1.1)$

$0.11( \pm 0.11)$

$0.00( \pm 0.02)$

$0.01( \pm 0.02)$

$0.05(+0.07)$

$0.01( \pm 0.01)$

$22( \pm 23)$

$2.6( \pm 2.1)$

$1.5( \pm 1.8)$

(.8.8)

$6.4( \pm 1.2)$

$500( \pm 75)$

$410( \pm 250)$

$7.0( \pm 2.8)$

$56( \pm 29)$

$160( \pm 80)$

$74( \pm 30)$

$46(! 110)$

$2.3(\div 0.72)$

$0.55( \pm 0.10)$

$0.59( \pm 0.06)$

$0.51( \pm 0.94)$

$3.6(+11)$

$0.45(\div 0.04)$

$0.70( \pm 1.3)$

$0.21( \pm 0.79)$

$0.06( \pm 0.16)$

$0.07( \pm 0.09)$

$0.12( \pm 0.14)$

$0.10(\div 0.16)$ $8.9(\div 14)$

$9.0( \pm 16)$

$3.5( \pm 2.4)$

$6.7( \pm 4.0)$

$4.5( \pm 1.8)$

$6.7( \pm 1.9)$

$4.9( \pm 7.2)$ $3400(\cdot 3000)$

$400(\cdot 3000)$ $100( \pm 140)$

$33( \pm 12)$

$29( \pm 4.2)$

$33( \pm .66)$

$25( \pm 23)$
$4( \pm 0.7)$ $0.4( \pm 0.7)$ $0.1( \pm 0.3)$ $0.0( \pm 1,0)$

$1.3( \pm 1.0)$ $1.0( \pm 0.6)$ $0.8( \pm 2.0$; $3.1( \pm 1.0)$ $1.7( \pm 2.0)$

$1.4( \pm 1.6)$ $1.7( \pm 1.1)$

$6.3( \pm 3.1)$ $1.3( \pm 1.0)$

$1.6( \pm 1.0)$

$0.8( \pm 0.7)$

$1.1( \pm 0.6)$

$3.1( \pm 1.7)$

$0.8( \pm 0.6)$

$3.1( \pm 2.1)$

$3.6(\div 3.5)$

$2.6(-2.7$

$2.6(\div 1.0)$

$3.2( \pm 1.3)$

11. $( \pm 9.7)$

1) $(45)$ 
TABLE XIV

RADIOACTIVITY IN OFF-SITE AND SUPPLY WATERS

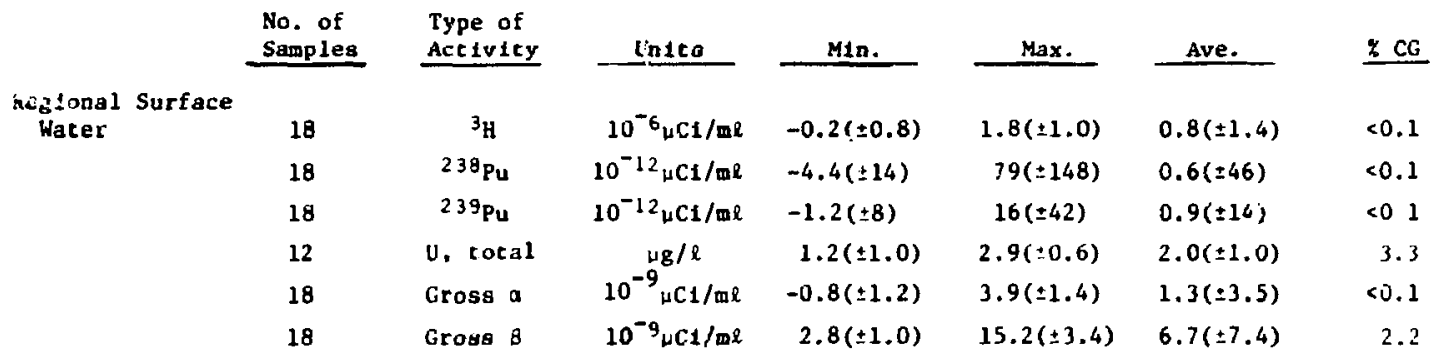

$\begin{array}{cc}\text { Perimeter Surface } & 14 \\ \text { and } & 18 \\ \text { Ground Water } & 18 \\ & 12 \\ 18 \\ 18\end{array}$

\begin{tabular}{|c|c|c|c|c|c|}
\hline${ }^{3} \mathrm{H}$ & $10^{-6}{ }_{\mu} \mathrm{C} 1 / \mathrm{ml}$ & $0.1( \pm 0.8)$ & $2.3( \pm 1.0)$ & $0.9( \pm 1.3)$ & $<0.1$ \\
\hline $2{ }^{38} \mathrm{Pu}$ & $\underline{1}^{-12}+C_{1} ; \dot{m i}$ & $-1.4( \pm 17)$ & $50(\div 100)$ & $1.5( \pm 34)$ & $<0.1$ \\
\hline $2{ }^{3}{ }^{9} \mathrm{Pu}$ & $10^{-12} \mu \mathrm{C} 1 / \mathrm{mi}$ & $-0.8( \pm 12)$ & $77( \pm 36)$ & $7.9( \pm 48)$ & $<0.1$ \\
\hline$U, \cot a l$ & $\mu 8 / R$ & $0.0( \pm 1.0)$ & $10( \pm 2.6)$ & $2.2( \pm 6.9)$ & 3.7 \\
\hline Gross a & $10^{-9} \mathrm{\mu Cl} / \mathrm{ml}$ & $-0.6( \pm 1.6)$ & $4.8(\div 2.6)$ & $0.8( \pm 3.2)$ & $<0.1$ \\
\hline Gross 8 & $10^{-9}{ }_{\mu \mathrm{Cl} / \mathrm{mR}}$ & $2.4( \pm 1.2)$ & $11( \pm 1.6)$ & $5.8( \pm 8.7)$ & 1.9 \\
\hline
\end{tabular}

\begin{tabular}{|c|c|c|c|c|c|c|c|}
\hline \multirow{6}{*}{$\begin{array}{l}\text { Los Alamos Water } \\
\text { Supply }\end{array}$} & 64 & ${ }^{3} \mathbf{H}$ & $10^{-6} \mu \mathrm{Cl} / \mathrm{ml}$ & $-0.9( \pm 0.8)$ & $1.5( \pm 1.0)$ & $0.3(=1.2)$ & $<0.1$ \\
\hline & 64 & ${ }^{238} \mathrm{Pu}$ & $10^{-12} \mu \mathrm{Cl} / \mathrm{ml}$ & $-1.0( \pm 18)$ & $60(\leq 60)$ & $-0.3( \pm 40)$ & $<0.1$ \\
\hline & 64 & $2.39 \mathrm{Pu}$ & $10^{-12} \mu \mathrm{C} 1 / \mathrm{ml}$ & $-1.1(: 12)$ & $29( \pm 26)$ & $-0.3( \pm 48)$ & $<0.1$ \\
\hline & 43 & $U$, total & $\mu g / \ell$ & $0.0( \pm 1.0)$ & $17( \pm 1.9)$ & $1.9( \pm 5.9)$ & 3.2 \\
\hline & 64 & Gross a & $10^{-g_{\mu}} \mathrm{Cl} / \mathrm{ml}$ & $-0.7( \pm 0.2)$ & $\therefore 0( \pm 4.0)$ & $0.9( \pm 3.1)$ & $<0.1$ \\
\hline & 64 & Gross $B$ & $10^{-9} \mathrm{\omega Cl} / \mathrm{ml}$ & $0.1(: 0.8)$ & $7.5( \pm 2.2)$ & $3.0( \pm 3.8)$ & 1.0 \\
\hline
\end{tabular}


TABLE XV

RADIOACTIVITY IN SOIL AND SEDIMENTS

Number of Samples
Type of

Activity

Unite

Min.

Max.

Ave.

Regional and Perimeter

So11s

9
18
18
19
19
19

${ }^{3} \mathrm{H}$
$2{ }^{28} \mathrm{Pu}$
$2{ }^{29} \mathrm{Pu}$
Gross a
Gross B
Total C

pCi/me

$1.9( \pm 1.0)$

$123( \pm 6)$

$16( \pm 80)$

$\mathrm{ACl} / \mathrm{B}$

$0.0( \pm 0.1)$

$3.5( \pm 3.2)$

$0.5( \pm 2.7)$

$\mathrm{fC} 1 / \mathrm{g}$

$0.0( \pm 0.0)$

$44( \pm 9.6)$

$12( \pm 25)$

$\mathrm{pCi} / \mathrm{s}$

$1.4( \pm 0.8)$

$8.0( \pm 3.6)$

$3.7( \pm 3.2)$

$\mathrm{pC1} / \mathrm{g}$

$2.5( \pm 0.8)$

$9.8( \pm 2.2)$

$5.8( \pm 3.5)$

$\mu \mathrm{g} / \mathrm{B}$

$<0.1( \pm 0.2)$

$2.7( \pm 0.4)$

$0.9( \pm 1.6)$

SedIments

$2{ }^{3} \mathrm{Pu}$

$\mathrm{fCl} / \mathrm{g}$

$0.0( \pm 7.2)$

$23{ }^{9} \mathrm{Pu}$

fC1/g

$-0.2( \pm 1.0)$

$2.8( \pm 3.0)$

$-0.4( \pm 5.4)$

Gross a

$\mathrm{PC1} / \mathrm{g}$

$1.1( \pm 0.6)$

$13( \pm 4.6)$

$2.5( \pm 10)$

Gross $B$

PC1/g

$5.0( \pm 2.0)$

$2.2( \pm 2.4)$

Toral U

$\mu_{\mathrm{g}} / \mathrm{g}$

$1.1( \pm 0.6)$

$6.4( \pm 2.6)$

$2.5( \pm 2.7)$

$<0.1( \pm 0.2)$

$3.8( \pm 1.2)$

$0.8( \pm 1.9)$

On-site

Sol1s

4
6
6
7
7
7

${ }^{3} \mathrm{H}$
$2{ }^{28} \mathrm{Pu}$
${ }^{2{ }^{9} \mathrm{Pu}}$
Gross a
Gross 5
Total $\mathrm{U}$

$\mathrm{pCi} / \mathrm{ap}$
$\mathrm{fCi} / \mathrm{g}$
$\mathrm{fC} 1 / \mathrm{g}$
$\mathrm{pC} 1 / \mathrm{g}$
$\mathrm{pCi} / \mathrm{g}$
$\mathrm{Hg} / \mathrm{g}$

$3.0( \pm 1.0)$

$-0.6( \pm 2.0)$

$8.3( \pm 1.0)$

$6.0( \pm 4.7)$

$2.8( \pm 1.8\rangle$

$2.8( \pm 2.6)$

$1.0( \pm 2.9)$

$2.9( \pm 1.4)$

$180( \pm 20)$

40( \pm 140$)$

Sediments

13
13
10
10
10

$\begin{array}{ccccc}238 \mathrm{Pu} & \mathrm{fCl} / \mathrm{g} & -0.2( \pm 1.2) & 5000( \pm 240) & 700( \pm 3400) \\ 239 \mathrm{Pu} & \mathrm{fCI} / \mathrm{g} & 0.1( \pm 1.4) & 1200( \pm 80) & 270( \pm 7150) \\ \text { Gross a } & \mathrm{pCl} / \mathrm{g} & 0.6( \pm 0.4) & 3.5( \pm 1.6) & 7.9( \pm 1.8) \\ \text { Gross B } & \mathrm{pCl} / \mathrm{g} & 0.2( \pm 0.4) & 5.6( \pm 2.4) & 2.5( \pm 3.3) \\ \text { Tocal v } & \mathrm{ug} / \mathrm{g} & : 0.1( \pm 0.4) & 1.3( \pm 0.4) & 0.5( \pm 0.9)\end{array}$




\begin{tabular}{|c|c|c|c|c|c|c|c|c|c|c|c|c|c|c|}
\hline \multirow[b]{2}{*}{$\begin{array}{l}\text { Source Sampled } \\
\text { Name \& Location }\end{array}$} & & \multirow[b]{2}{*}{$\begin{array}{l}\text { No. \& Type } \\
\text { of Sample }\end{array}$} & \multicolumn{10}{|c|}{ Average Chemical Concentrat long (mg/R) } & \multirow[b]{2}{*}{ pH } & \multirow[b]{2}{*}{$\begin{array}{c}\text { Conductance } \\
\mathrm{mS} / \mathrm{m}\end{array}$} \\
\hline & & & $\mathrm{Ca}^{2+}$ & $\underline{\mathrm{Mg}}^{2+}$ & $\underline{\mathrm{Na}}^{+}$ & $\underline{\mathrm{CO}}_{3}{ }^{2-}$ & $\mathrm{HCO}_{3}^{-}$ & $\mathrm{Cl}^{-}$ & $E^{-}$ & $\mathrm{NO}_{3}^{-}$ & $\underline{\text { TDS }}$ & Hard & & \\
\hline \multicolumn{15}{|l|}{ Noneff luent Areas } \\
\hline Test Well 3 & N 80 E120 & $2-\mathbf{G}$ & 18 & 6 & 18 & $\mathbf{0}$ & 90 & 6 & 0.8 & 1.3 & 188 & 69 & 7.4 & 19.8 \\
\hline Canada del Buey & N 10 E150 & $1-5$ & 10 & 1 & 7 & 0 & 40 & 10 & .5 & .9 & 180 & 28 & 7.2 & 10.4 \\
\hline Pajarito Canyon & S 60 E225 & $2-5$ & 34 & 10 & 2.5 & 0 & 54 & 87 & .5 & 4.2 & 347 & 128 & 7.4 & 44.2 \\
\hline Water Canyon & S 90 E 85 & $1-5$ & 10 & 1 & 19 & 0 & 52 & 10 & $<.1$ & 2,2 & 190 & 28 & 7.2 & 14.0 \\
\hline Test Well DT-5A & S110 E 90 & $2-G$ & 10 & 3 & 11 & 0 & 60 & 4 & .7 & 1.6 & 142 & 38 & 7.6 & 12.5 \\
\hline Test We11 8 & N $40 \mathrm{E} 150$ & 2-G & 11 & 4 & 12 & 0 & 68 & 5 & .4 & .2 & 108 & 47 & 7.9 & 13.5 \\
\hline \multicolumn{15}{|c|}{ Acid-Pueblo Canjon (Former Release Area) } \\
\hline Acid Weit & N130 E 60 & $2-5$ & 22 & 4 & 59 & $\mathbf{0}$ & 95 & 50 & .7 & 26 & 324 & 74 & 7.7 & 50.5 \\
\hline Pueb1o 1 & N130 E 75 & $2-s$ & 8 & 6 & 61 & 0 & 64 & 39 & .7 & 42 & 362 & 50 & 7.3 & 46.5 \\
\hline Pueblo 2 & N115 E160 & 2-S & 14 & 4 & 64 & $\mathbf{0}$ & 79 & 38 & .6 & 36 & 225 & 54 & 7.2 & 45.5 \\
\hline Obs. Hole PO-3B & N110 E245 & $2-G$ & 30 & 9 & 23 & 0 & 78 & 31 & .4 & 13 & 299 & 113 & 7.6 & 37.0 \\
\hline Hamlltion Bend Spring & N110 E250 & $2-G$ & 11 & 6 & 70 & $\mathbf{0}$ & 90 & 37 & .9 & 22 & 359 & 51 & 7.7 & 46.5 \\
\hline Pueblo 3 & N 85 E315 & $2-5$ & 12 & 6 & 72 & c & 97 & 36 & .8 & 48 & 380 & 56 & 7.2 & 53.5 \\
\hline \multicolumn{15}{|l|}{ Sandia Canyon } \\
\hline scs-1 & N 80 E 40 & $2-s$ & 74 & 22 & 108 & $\mathbf{0}$ & 162 & 258 & 1.0 & 21 & 964 & 279 & 7.4 & 120 \\
\hline $\operatorname{scs}-2$ & N 55 E155 & $2-5$ & 32 & 10 & 106 & 3 & 166 & 66 & 1.2 & 4.4 & 579 & 122 & 8.2 & 80 \\
\hline \multicolumn{15}{|l|}{ DP-Los Alamos Canyon } \\
\hline DPS-1 & N 95 E160 & $2-s$ & 16 & 3 & 176 & 18 & 334 & 65 & 2.3 & 59 & 816 & 54 & 8.8 & 108 \\
\hline DPS-4 & N 80 E205 & 2-s & 20 & 2 & 107 & 0 & 169 & 46 & 2.9 & 67 & 479 & 57 & 7.6 & 73.5 \\
\hline Obs. Hole LAO-C & N 85 E 70 & 2-G & 16 & 4 & 35 & 0 & 67 & 46 & .2 & .9 & 213 & 61 & 7.4 & 31.0 \\
\hline Cbs. Hole $1 . A O-1$ & N 85 E115 & 2-G & 21 & 3 & 58 & 0 & 77 & 56 & 1.0 & 13 & 344 & 72 & 7.7 & 45.5 \\
\hline Obs. Hole $1 \mathrm{AO}-2$ & N 80 E2C5 & $2-G$ & 18 & 3 & 77 & 2 & 153 & 42 & 3.6 & 42 & 476 & 58 & 8.2 & 62.0 \\
\hline Obs. Hole $1 . A 0-3$ & N 80 E215 & 2-G & 24 & 3 & 70 & 2 & 152 & 38 & 2.8 & 47 & 411 & 76 & 7.9 & 60.2 \\
\hline Obs. Hole LAO-4.5 & N 65 E270 & $2-G$ & 16 & 3 & 39 & 0 & 91 & 25 & 1.8 & 8.8 & 252 & 55 & $? .4$ & 33.5 \\
\hline \multicolumn{15}{|l|}{ Mortandad Canyon } \\
\hline Gaging Station 1 & N 50 E 90 & $2-5$ & 16 & 4 & 86 & 2 & 108 & 12 & .6 & 116 & 429 & 54 & 8.2 & 58.5 \\
\hline Obs. Hole $\mathrm{MCO}^{-3}$ & N 45 E 95 & $2-6$ & 34 & 2 & 152 & $\mathbf{0}$ & 224 & 20 & .6 & 303 & 792 & 99 & 8.1 & 116 \\
\hline Obs. Hole HCO-4 & N 35 E135 & $7-6$ & 18 & 4 & 128 & 4 & 223 & 18 & 1.0 & 119 & 554 & 59 & 8.4 & 82.5 \\
\hline Obs. Hole MCO-5 & N 40 E150 & $2-6$ & 19 & 4 & 114 & 8 & 229 & 20 & 1.1 & 116 & 557 & 67 & 8.6 & 78.0 \\
\hline Obs. Hole $\mathrm{MCO} 6$ & N 35 E160 & 2-G & 15 & 5 & 130 & 12 & 229 & 21 & 1.5 & 100 & 619 & 58 & 8.4 & 88.0 \\
\hline Obs. Hole MCO-7 & N $30 \quad E 170$ & $2-G$ & 22 & 4 & 122 & 6 & 229 & 22 & .5 & 104 & 540 & 70 & 8.4 & 91.2 \\
\hline Obs, Hole Mc0-7.5 & N $30 \mathbf{E 1 8 0}$ & $2-\mathbf{G}$ & 23 & 6 & 135 & 0 & 246 & 22 & .4 & 126 & 618 & 85 & 8.0 & 91.0 \\
\hline Obs. Hole $\mathrm{MCO}-8$ & N 30 E185 & 2-G & 42 & 10 & 120 & 2 & 211 & 26 & .5 & 160 & 629 & 145 & 8.0 & 93.5 \\
\hline
\end{tabular}


TABLE XVII

CHEMICAL QUALITY OF PERTMETER SURFACE AND GROLND WATERS

\section{Sampling Locations}

Los Alamos Reservoir

Guaje Canyon

Basalt Spring

La Mesita Spring

Test Well IA

Frijoles Canyon
No. 8 Type

of Sample

N105 W 75

N215 E315

N $65 \quad$ E395

$18 \mathrm{~km}$ E of L.A. $\quad 2-C$

N 70 E300

S280 E190
2-S

2-S

$2-G$

$2-\mathrm{G}$

2-s

$\begin{array}{rlrc}\underline{\mathrm{Ca}}^{2+} & \mathrm{Mg}^{2+} & { }^{+} & \mathrm{CO}_{3}{ }^{2-} \\ 8 & 2.5 & 5 & 0 \\ 7.5 & 3.5 & 9 & 0 \\ 23 & 7 & 13 & 0 \\ 32 & 1 & 26 & 0 \\ 20 & 8 & 63 & 0 \\ 10 & 3.5 & 10 & 0\end{array}$

$\frac{\mathrm{HCO}}{3}_{3}^{-}$
35
40
81
116
109
43

$\begin{array}{rlrrrrr}\underline{\mathrm{Cl}}^{-} & \mathrm{F}^{-} & \underline{\mathrm{NO}}_{3}^{-} & \underline{\mathrm{TDS}} & \underline{\mathrm{Hard}} & \underline{\mathrm{pl}} & \begin{array}{c}\text { Conductance } \\ (\mathrm{mS} / \mathrm{m})\end{array} \\ 4 & 0.2 & 0.4 & 147 & 30 & 7.3 & 10 \\ 3 & 0.3 & 0.6 & 136 & 34 & 7.3 & 10 \\ 15 & 0.6 & 10 & 209 & 93 & 7.6 & 29 \\ 9 & 0.2 & 9.9 & 223 & 84 & 8.0 & 30 \\ 39 & 1.6 & 26 & 326 & 81 & 7.4 & 49 \\ 4.5 & 0.2 & 0.2 & 159 & 39 & 8.0 & 11\end{array}$




\section{TABLE XVIII}

CHEMICAL QUALITY OF REGIONAL SURFACE WATER

Analyses
Bicarbonate
Calcium
Carbonate
Chloride
Fluor dde
Magnestum
Nitrate
Sodium
TDS
Hardness
pH
Conductance (mS/m)

No. of Analyses

14
14
14
14
14
14
14
14
14
14
14
14

Concentrations (mg/le)

\begin{tabular}{rrc}
\hline Min & Max & Av \\
\hline 74 & 192 & $120( \pm 68)$ \\
25 & 59 & $43( \pm 18)$ \\
0 & 10 & $1.1( \pm 6.0)$ \\
5 & 111 & $26( \pm 70)$ \\
0.2 & 1.0 & $0.47( \pm 0.51)$ \\
2 & 14 & $6.9( \pm 6.0)$ \\
0.4 & 1.3 & $0.81( \pm 0.87)$ \\
11 & 84 & $32( \pm 44)$ \\
176 & 470 & $310( \pm 170)$ \\
72 & 206 & $140( \pm 65)$ \\
7.4 & 8.4 & $7.9( \pm 0.6)$ \\
20 & 74 & $45( \pm 31)$
\end{tabular}


TABLE XIX

CHEMICAL QUALITY OF THE LOS ALAMOS WATER SUPPLY

\begin{tabular}{|c|c|c|c|c|c|}
\hline \multirow[b]{2}{*}{ Analyses } & \multirow[b]{2}{*}{ Ne. of Analyses } & \multicolumn{3}{|c|}{ Concentrations $(\mathrm{mg} / \ell)$} & \multirow[b]{2}{*}{$\%$ std $^{a}$} \\
\hline & & Min & Max & Av & \\
\hline Arsenic & 57 & 0.001 & 0.23 & $0.02( \pm 0.08)$ & 40 \\
\hline Bicarbonate & 42 & 34 & 300 & $101( \pm 105)$ & - \\
\hline Calcium & 42 & 3 & 26 & $12.7( \pm 12)$ & - \\
\hline Carbonate & 42 & $\mathbf{0}$ & 16 & $0.8( \pm 2.7)$ & - \\
\hline Chloride & 42 & $<0.1$ & 18 & $5.2( \pm 7.2)$ & - \\
\hline Chromlum & 57 & $<0.0001$ & 0.029 & $0.007( \pm 0.014)$ & 14 \\
\hline Fluoride & 42 & 0.1 & 2.4 & $0.7( \pm 1.2)$ & 35 \\
\hline Magneslum & 42 & $<1$ & 10 & $2.7( \pm 4.8)$ & - \\
\hline Mercury & 6 & $<0.0002$ & 0.0002 & 0.0002 & 10 \\
\hline Nitrates & 42 & $<0.4$ & 3.9 & $1.5( \pm 1.7)$ & 3.4 \\
\hline Selenium & 57 & $<0.0002$ & 0.0005 & $0.0002( \pm 0.0002)$ & 2 \\
\hline Silica & 41 & 32 & 92 & $61( \pm 41)$ & - \\
\hline Sodium & 42 & 4 & 132 & $30( \pm 53)$ & - \\
\hline TDS & 41 & 48 & 510 & $190( \pm 170)$ & - \\
\hline Hardness & 42 & 8 & 104 & $42( \pm 48)$ & - \\
\hline $\mathrm{pH}$ & 42 & 7.1 & 8.6 & $8.0( \pm 0.6)$ & - \\
\hline Conductance (mS/m) & 42 & 4 & 65 & $21( \pm 23)$ & $=$ \\
\hline
\end{tabular}

a Percent of drinking water standard (EPA National Interim Primary Drinking Weter Standerds). 
CHEMICAL QUALITY OF WATER IN THE VICINITY OF PENTON HILl.

\begin{tabular}{|c|c|c|c|c|c|c|}
\hline Number of Stations & $\begin{array}{c}\begin{array}{c}\text { Surface } \\
\text { Water }\end{array} \\
9\end{array}$ & $\begin{array}{c}\begin{array}{c}\text { Water Supply } \\
\text { (Jemez Sps-LaCueva) }\end{array} \\
3\end{array}$ & $\begin{array}{c}\begin{array}{c}\text { Springs } \\
\text { (Jemez Fau1t) }\end{array} \\
3\end{array}$ & $\begin{array}{c}\text { Springs } \\
\text { (Recent: Volcan ICs) } \\
5\end{array}$ & $\begin{array}{c}\begin{array}{c}\text { Misc. Well } \\
\text { and Test Holes }\end{array} \\
\frac{3}{3}\end{array}$ & $\begin{array}{c}\begin{array}{c}\text { Fenton Hill } \\
\text { (Drilling Fluids) }\end{array} \\
3\end{array}$ \\
\hline $\begin{array}{l}\text { Number of Samples } \\
\text { Analyses (mg/ } / 2)\end{array}$ & 27 & 9 & 7 & 9 & 5 & 4 \\
\hline Bicarbonate & $80( \pm 130)$ & $68( \pm 15)$ & $720( \pm 890)$ & $77( \pm 55)$ & $250( \pm 390)$ & $240( \pm 440)$ \\
\hline Calcium & $31( \pm 37)$ & $13( \pm 4.6)$ & $120( \pm 140)$ & $9.3( \pm 6.2)$ & $19( \pm 24)$ & $42( \pm 52)$ \\
\hline Carbonate & $0.9(14.9)$ & $O( \pm 0)$ & $8( \pm 42)$ & $0( \pm 0)$ & $0.0( \pm C .0)$ & $78( \pm 310)$ \\
\hline Chloride & $26( \pm 71)$ & $3.9( \pm 3.9)$ & $760( \pm 1100)$ & $6.3( \pm 7.4)$ & $3.8( \pm 5.4)$ & $145( \pm 435)$ \\
\hline Fluoride & $0.6( \pm 0.7)$ & $0.2( \pm 0.1)$ & $2.7( \pm 2.2)$ & $0.9( \pm 0.5)$ & $1.0( \pm 1.1)$ & $1.1( \pm 1.3)$ \\
\hline Magnestum & $4.6(\leq 6,2)$ & $3.6( \pm 2.0)$ & $28( \pm 35)$ & $2.9( \pm 3.2)$ & $5.6( \pm 9.6)$ & $3.2( \pm 4.4)$ \\
\hline Nitrates & $0.6( \pm 0.4)$ & $1.3( \pm 1.3)$ & $1.3( \pm 3.3)$ & $1.0( \pm 2.0)$ & $2.6( \pm 3.2)$ & $3.6( \pm 8.1)$ \\
\hline Silica & $41( \pm 23)$ & $57( \pm 63)$ & $44( \pm 16)$ & $65( \pm 31)$ & $66( \pm 19)$ & $50( \pm 54)$ \\
\hline Sodium & $25( \pm 50)$ & $14( \pm 2.8)$ & $550( \pm 670)$ & $24( \pm 32)$ & $73( \pm 110)$ & $120( \pm 78)$ \\
\hline Sulfate & $40( \pm 170)$ & $5.6( \pm 9.3)$ & $71( \pm 200)$ & $7.6( \pm 10)$ & $2.5( \pm 3.1)$ & $170( \pm 340)$ \\
\hline TDS & $240( \pm 290)$ & $160( \pm 55)$ & $2400( \pm 2500)$ & $176( \pm 112)$ & $350( \pm 430)$ & $1200( \pm 2000)$ \\
\hline Hardness (as $\mathrm{CaCO}_{3}$ ) & $95( \pm 110)$ & $49( \pm 17)$ & $400( \pm 420)$ & $35( \pm 27)$ & $70( \pm 94)$ & $120( \pm 140)$ \\
\hline pH & $7.5( \pm 2.5)$ & $7.6( \pm 0.7)$ & $7.4( \pm 1.1)$ & $7.8( \pm 0.6)$ & $7.6( \pm 0.3)$ & $8.5( \pm 3.5)$ \\
\hline Conductance $(\mathrm{mS} / \mathrm{m})$ & $34( \pm 47)$ & $15( \pm 31)$ & $420( \pm 450)$ & $18( \pm 12)$ & $47( \pm 69)$ & $170( \pm 260)$ \\
\hline
\end{tabular}

Sampling locations keyed on Fig. 10 as follows.

Surface Water - F, J, N, Q, R, S, T, U, V.

Water Supply (Jemez Springs-LaCueva) - JS-2 and JS-3, JS-4 and JS--5, 4.

Springs (Jemez Fault) - JF-1, JF-5, JF-9.

Springs (Recent Volcanics) - 31, RV-1, RV-2, RV-4, RV-5.

Miscellaneous Well and Test Holes $-27, \mathrm{H}-2, \mathrm{H}-7$.

Fenton Hill (Drilling FIuids) - TA-57. 
TABLE XXI

RIO GRANDE RADIONUCLIDE SURVEY

\begin{tabular}{|c|c|c|c|c|c|}
\hline \multirow[b]{2}{*}{ Year } & \multirow[b]{2}{*}{ Month } & \multicolumn{3}{|c|}{ Fish $(\mathrm{fCl} / \mathrm{g} \mathrm{drv})^{a}$} & \multirow[b]{2}{*}{${ }^{239} \mathrm{Pu}$} \\
\hline & & No. Samples & ${ }^{137} \mathrm{Cs}$ & ${ }^{238} \mathrm{Pu}$ & \\
\hline \multirow[t]{2}{*}{1973} & Sept. & 6 & $330(53 \%)$ & NC & NC \\
\hline & & & $100-510$ & & \\
\hline \multirow[t]{2}{*}{1974} & May & 3 & $46(120 \%)$ & NC & NC. \\
\hline & & & $0-100$ & & \\
\hline \multirow[t]{2}{*}{1974} & Sept. & 19 & $860(69)$ & $0.0(0.07)$ & $0.9(210 \%$ \\
\hline & & & $0-\mathbf{1} 800$ & 0 & $0-7.0$ \\
\hline
\end{tabular}

\begin{tabular}{|c|c|c|c|}
\hline \multicolumn{4}{|c|}{ Seriment $(\mathrm{f} \mathrm{Ci} / \mathrm{g} \mathrm{dry})^{\mathrm{a}}$} \\
\hline No. Samples & ${ }^{137} \mathrm{Cs}$ & ${ }^{238} \mathrm{Pu}$ & ${ }^{239} \mathrm{Pu}$ \\
\hline \multirow[t]{2}{*}{11} & -- & $3.4(74 \%)$ & $4.7(57 \%)$ \\
\hline & & $1.0-9.0$ & $2.0-8.0$ \\
\hline \multirow[t]{2}{*}{10} & - & $0.5(420 \pi)$ & $2.2(45 \pi)$ \\
\hline & & $0-5.0$ & $0.1-5.6$ \\
\hline \multirow[t]{2}{*}{14} & - & $0.4(2108)$ & $7,4(1407)$ \\
\hline & & $0-2.0$ & $0-39$ \\
\hline
\end{tabular}

Mean (100x o/mean $\%)$; range.

NC: nor completed. 